\title{
VARIABILIDADE GENÉTICA DE ISOLADOS DE Fusarium spp. E ESTUDO DA INTERAÇÃO COM A PLANTA HOSPEDEIRA
}

\author{
Mayra KassaWARA MaRtins
}

Tese apresentada à Escola Superior de Agricultura "Luiz de Queiroz", Universidade de São Paulo, para obtenção do título de Doutor em Agronomia, Área de Concentração: Genética e Melhoramento de Plantas.

PIRACICABA

Estado de São Paulo - Brasil

Fevereiro - 2005 


\title{
VARIABILIDADE GENÉTICA DE ISOLADOS DE Fusarium spp. E ESTUDO DA INTERAÇÃO COM A PLANTA HOSPEDEIRA
}

\author{
MAYRa KassaWARA MARTINS
}

Bióloga

Orientadora: Prof ${ }^{a}$. Dr ${ }^{a}$ ALINE A. PIZZIRANI-KLEINER

Tese apresentada à Escola Superior de Agricultura "Luiz de Queiroz", Universidade de São Paulo, para obtenção do título de Doutor em Agronomia, Área de Concentração: Genética e Melhoramento de Plantas.

PIRA CICAB A

Estado de São Paulo - Brasil

Fevereiro - 2005 
Dados Internacionais de Catalogação na Publicação (CIP) DIVISÃO DE BIBLIOTECA E DOCUMENTAÇÃO - ESALQ/USP

Martins, Mayra Kassawara

Variabilidade genética de isolados de Fusarium spp. e estudo da interação com a planta hospedeira / Mayra Kassawara Martins. - - Piracicaba, 2005.

110 p. : il.

Tese (Doutorado) - - Escola Superior de Agricultura Luiz de Queiroz, 2005. Bibliografia.

1. Fusarium 2. Marcador molecular 3. Relação planta-fungo 4. Soja 5. Tomate 6. Variação genética I. Título

CDD 633.34 


\begin{abstract}
Aos meus pais Arlindo e Shigue, os
grandes responsáveis pela minha

formação, pelo amor e carinho constantes,

pela alegria, compreensão e incentivo

durante toda a minha vida.
\end{abstract}

\title{
Dedico
}

As minhas irmãs que amo tanto Mayrise e Maylena, aos meus cunhados Vlademir e Vítor Fabiano e aos meus queridos sobrinhos, Danilo e Débora, pelo apoio, carinho, amor e torcida para o meu sucesso. 


\section{AGRADECIMENTOS}

Agradeço a todos aqueles que tornaram possível a realização deste trabalho e de forma especial:

À Profa. Dra. Aline A. Pizzirani-Kleiner pela orientação, por ter me apoiado nos momentos mais difíceis, pela confiança e pela valiosa amizade.

Ao Dr. Welington Luiz de Araújo pelo apoio indispensável no desenvolvimento desta tese, pela atenção e paciência constantes e a quem tenho profundo agradecimento.

Ao Prof. Dr. João Lúcio de Azevedo pelas sugestões, pelo seu exemplo profissional e a quem admiro muito.

Aos amigos do Laboratório de Genética de Microrganismos: Adalgisa, Ágata, Aline (Romã), Andrea Guelfi, Cláudia, Fernando (Moska), Heloíze, Joelma, José Antonio (Zezo), Júlia, Léia, Kadú, Luciana, Maria Beatriz (Bia), Carolina Quecine, Maria Clara, Manuela, Paulo Lacava, Priscilla, Ricardo Yara (Pipa), Rodrigo Mendes (Xico), Rodrigo Stuart, Rudi, Sonia, Taís, Uirá e Vivian, pelo companheirismo e alegrias compartilhadas que resultaram num reforço de nossa amizade. 
Aos grandes amigos Ágata Giancoli, Carolina Quecine, Cristina Maki, Joelma Marcon e José Antonio (Zezão), pela valiosa amizade, carinho e incentivos dados nos momentos mais difíceis.

A amiga Luciana Cursino pela amizade e valiosas sugestões.

Aos amigos Marisa Monteiro, Andréa Spessoto e Rodrigo Brogin pelo incentivo e amizade.

À todos os professores e colegas de Curso de pós graduação em Genética e Melhoramento de Plantas ESALQ/USP.

Aos funcionários do Departamento de Genética ESALQ/USP, em especial a Léia, Glória pelo apoio de ordem administrativa.

À CAPES pela bolsa de doutorado concedida e a FAPESP pelo apoio financeiro. 


\section{SUMÁRIO}

Página

RESUMO

$X$

SUMMARY

XII

1 INTRODUÇÃO

2 REVISÃO BIBLIOGRÁFICA

2.1 Fusarium spp.

2.1.1 Aspectos Gerais

2.1.2 Métodos de Controle

2.2 Análise da Variabilidade Genética por Marcadores Moleculares .....

2.2.1 Variabilidade Genética por Sequenciamento do rDNA e

ARDRA

2.2.2 Variabilidade Genética via RAPD

2.3 Interação Fungo/Planta

2.3.1 Microrganismos Endofíticos no Controle de Patógenos de

Plantas 


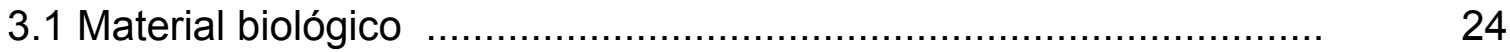

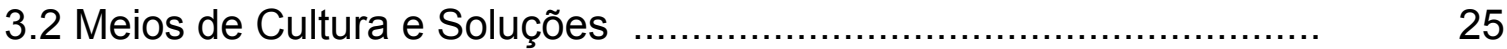

3.2.1 Meio Batata Dextrose Ágar (BDA) ………............................... 25

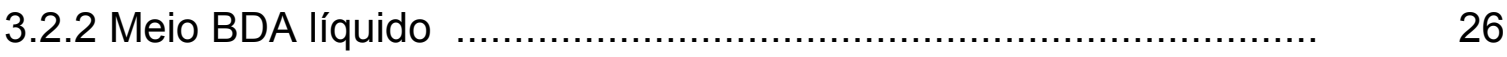

3.2.3 Tampão de corrida TAE 50x ................................................ 26

3.2.4 Solução de brometo de etídio (Sambrook et al., 1989) ................. 26

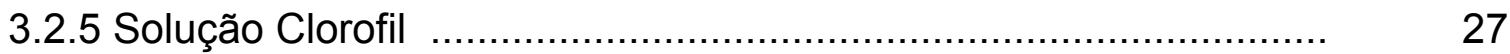

3.2.6 Solução Clorofane ............................................................ 27

3.2.7 Fenol saturado (Sambrook et al., 1989) ..................................... 27

3.2.8 Solução estoque Tris-HCl 1M pH 8,0 …….............................. 28

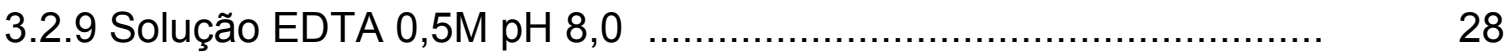

3.2.10 $\mathrm{NaCl} 5 \mathrm{M}$

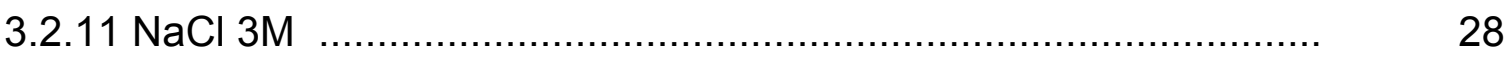

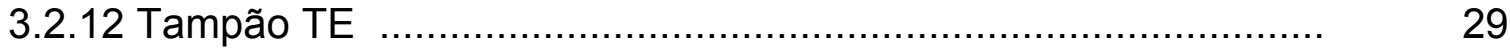

3.2.13 SDS 10\%

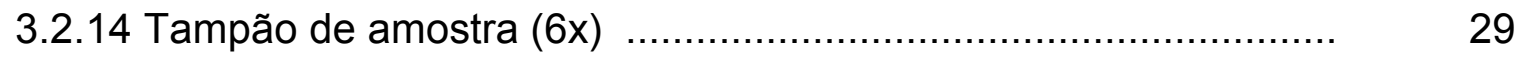

3.2.15 Tampão de extração de DNA de fungos filamentosos

(Raeder \& Broda, 1985) ..................................................

3.2.16 Primers de RAPD ......................................................... 30

3.2.17 Primers da região ITS do rDNA ………................................ 30 
3.4. Extração de DNA de fungos filamentosos (Raeder \& Broda, 1985)

3.7 Análise de restrição do produto de amplificação do rDNA (ARDRA)

3.10 Análise da diversidade de isolados de Fusarium spp. por meio

Do índice de Shannon

3.11.1 Bioensaio - controle biológico

11.1.1 Reisolamento de Fusarium spp

3.11.1.2 Análise dos Dados

3.11.2 Interação de isolados de Fusarium spp. em plantas de tomate e soja 
4.2 Variabilidade genética de Fusarium spp. por meio da análise da

Região ITS do rDNA

4.2.1 Amplificação e restrição do rDNA (ARDRA)

4.3 Análise da variabilidade genética de Fusarium spp, via RAPD ....... 58

4.3.1 Otimização da técnica de RAPD e seleção de

Oligonucleotídeos

58

4.3.2 Polimorfismo por RAPD

59

4.2.2.1 Análise da diversidade de isolados de Fusarium por meio do índice de Shannon

4.2.3 Análise da variabilidade genética de $F$. oxysporum

4.3 Interação fungo-planta 71

4.3.1 Reisolamento de Fusarium spp. em plantas de tomate

4.3.2 Interação de isolados de Fusarium spp. em plantas de tomate e soja

78

5 CONCLUSÕES 


\title{
VARIABILIDADE GENÉTICA DE ISOLADOS DE Fusarium spp. E ESTUDO DA INTERAÇÃO COM A PLANTA HOSPEDEIRA
}

\author{
Autora: MAYRA KASSAWARA MARTINS \\ Orientadora: Profa. Dra. ALINE A. PIZZIRANI-KLEINER
}

\section{RESUMO}

O Fusarium spp. é um fungo cosmopolita, compreendendo uma grande quantidade de espécies que são conhecidas por causar doenças em culturas de importância agronômica. Embora, isolados não patogênicos de Fusarium spp. tenham sido descritos, pouco se conhece sobre a variabilidade genética deste grupo, ainda que estejam presentes em inúmeros locais. Assim sendo, este trabalho teve como objetivos ampliar estes conhecimentos, avaliando a variabilidade genética e forma de interação de isolados patogênicos e não patogênicos de Fusarium spp. obtidos de diferentes hospedeiros. Desta forma, 83 isolados de Fusarium spp. foram avaliados por meio das técnicas de ARDRA, sequenciamento do rDNA e RAPD. A análise por meio de ARDRA, permitiu a distinção dos 83 isolados de Fusarium spp. em 19 haplótipos, apresentando uma grande diversidade dentro de cada haplótipo, mas de forma 
geral os isolados patogênicos e não patogênicos de Fusarium spp. não puderam ser discriminados. Nas análises de sequenciamento da região ITS do rDNA, foi observado que isolados de Fusarium se agruparam independentemente da espécie. Estes resultados comprovam a necessidade de uma revisão taxonômica dentro do gênero Fusarium. A análises por marcadores RAPD revelou que os 83 isolados de Fusarium spp. avaliados neste estudo apresentaram ampla variabilidade a qual não está correlacionada com a característica taxonômica. Entretanto, foi observado que isolados patogênicos e endofíticos de $F$. oxysporum obtidos de soja são geneticamente diferentes. Quanto às análises de interação de isolados patogênicos e não patogênicos de Fusarium spp. com cultivares susceptíveis de tomate e soja, verificou-se que estes isolados interagiram de forma diversa, nos diferentes tecidos vegetais, sendo que alguns isolados endofíticos promoveram o crescimento vegetal. Dentre estes, destaca-se o isolado endofítico Cac19.4 que mostrou-se geneticamente diferente de isolados patogênicos de Fusarium spp., além de promover um aumento de peso da raiz e caule de plântulas de soja e tomate. Dessa forma este isolado poderia ser selecionado para futuras análises, visando um melhor aproveitamento deste microrganismo endofítico em estudos de interesse agronômico. 


\title{
GENETIC VARIABILITY OF Fusarium spp. AND STUDY OF ITS INTERACTION WITH THE HOST PLANT
}

\author{
Author: MAYRA KASSAWARA MARTINS \\ Adviser: Dr. ALINE A. PIZZIRANI-KLEINER
}

\section{SUMMARY}

Fusarium spp. is a cosmopolitan fungus that covers a great number of species known by the ability of causing diseases in agricultural important crops. Although non-pathogenic isolates of Fusarium spp. have been described, little is known about the genetic variability of this group, even if it can be found in countless places. Therefore, this work had the objectives of increase this knowledge, evaluating the genetic variability and modes of interaction between Fusarium spp pathogenic and non-pathogenic isolates, obtained from different hosts. In this way, ARDRA, rDNA sequencing, and RAPD techniques evaluated 83 Fusarium spp. isolates. The ARDRA analysis allowed the separation of 83 isolates in 19 haplotypes. In spite of the great diversity found inside each haplotypes, in general it was difficult to distinguish pathogenic and nonpathogenic isolates. In the sequencing analysis of the ITS region of rDNA, it was 
observed that Fusarium isolates were grouped together independently to the species. These results proved the need for a taxonomic review inside Fusarium genera. The RAPD analysis revealed that the 83 Fusarium spp. isolates evaluated in this study presents high levels of variability not correlated with the taxonomic characteristic. However, we observed that pathogenic and endophytical $F$. oxysporum isolated from soybean are genetically different. The interaction analysis between pathogenic and non-pathogenic isolates of Fusarium spp. with susceptible cultivars of tomato and soybean, showed different modes of interaction on different plant tissues, where some endophytical isolates increased plant growth. Among these, we can emphasize the endophytic isolate Cac19.4, that is genetically different if compared with Fusarium spp. pathogenic isolates, in spite of his ability to promote an increase in root and stems weight of soybean and tomato plantlets. Thus, this isolate could be selected for further analysis, looking for a better use of this endophytical microorganism in agricultural interest studies. 


\section{INTRODUÇÃO}

O fungo Fusarium spp. é amplamente distribuído ao redor do mundo, encontrado em todos os tipos de solo ou associados a inúmeras espécies vegetais. Este fungo pode sobreviver por longos períodos de forma saprofítica sobre a matéria orgânica do solo e quando possível pode causar inúmeras doenças em diferentes espécies vegetais, sobretudo em culturas de importância econômica, causando grandes prejuízos.

Embora o maior interesse neste fungo se deve ao fato de causar doenças em um grande número de espécies vegetais, dentro do gênero Fusarium isolados não patogênicos têm sido descritos. Entretanto, poucos estudos foram realizados com a finalidade de comparar a variabilidade genética neste grupo, embora estejam presentes em inúmeros locais e representem um dos maiores componentes da comunidade do solo. Além disso, isolados não patogênicos podem ser encontrados, endofiticamente, colonizando o interior da planta hospedeira. Estes isolados endofíticos podem apresentar interação simbiótica com o hospedeiro, sendo importantes, não só para o controle biológico de doenças, mas também desempenhando funções que poderão ser benéficas para a planta hospedeira. Neste contexto são de extrema importância 
o conhecimento da estrutura populacional deste grupo e entender a compreensão da variabilidade genética presente neste gênero.

Sabe-se ainda que isolados patogênicos de Fusarium spp. mostram um alto nível de especificidade ao seu hospedeiro, mas a relação destes isolados com isolados não patogênicos ainda não foi avaliada. Dessa forma, o conhecimento das relações filogenéticas entre isolados patogênicos e não patogênicos de Fusarium spp. obtidos de diferentes hospedeiros, poderá favorecer o entendimento das relações existentes neste grupo. Estes estudos permitirão a utilização destes conhecimentos para o controle de doenças causadas por este fungo e também o desenvolvimento de um sistema agrícola utilizando isolados endofíticos de Fusarium spp.

Diante do exposto, o presente trabalho teve como objetivos:

1) Estudar a diversidade genética de isolados de Fusarium spp. por meio da técnica de ARDRA e por meio da análise de seqüenciamento da região ITS do rDNA;

2) Avaliar a variabilidade genética de isolados de Fusarium spp. por meio de marcadores de RAPD;

3) Verificar a ocorrência de especificidade de genótipos patogênicos e não patogênicos de Fusarium spp. à diferentes hospedeiros por meio de marcadores de RAPD e seqüenciamento de regiões ITS do rDNA;

4) Avaliar a interação de isolados patogênicos e não patogênicos de Fusarium spp. em diferentes hospedeiros. 


\section{REVISÃO DA LITERATURA}

\subsection{Fusarium spp.}

\subsubsection{Aspectos gerais}

O gênero Fusarium é caracterizado pelo seu crescimento rápido, colônias com coloração pálida ou colorida (violeta à púrpura escuro ou do creme à laranja), com micélio aéreo e difuso (Domsch et al., 1980). A maioria das espécies de Fusarium é composta por fungos de solo com distribuição cosmopolita e ativo na decomposição de substratos celulósicos das plantas, sendo que alguns isolados são parasitas das plantas. A patogenicidade ao homem é rara, mas muitas espécies causam o apodrecimento de estoques e são importantes produtoras de toxinas (Desjardins et al., 2000; Leslie et al., 2001; Zemankova \& Lebeda, 2001;Godoy \& Colombo, 2004).

As duas principais formas de esporos de Fusarium são os microconídios e os macroconídios. Os microconídios são unicelulares e uninucleados; os macroconídios mais comuns são multicelulares, mas cada célula tem somente um núcleo. Todos os núcleos de um macroconídio, contudo, são descendentes 
mitóticos de um mesmo núcleo progenitor e são, portanto geneticamente idênticos (Puhalla, 1981). Ainda segundo Puhalla (1981), os estágios sexuais de Fusarium são ascomicetos; o esporo sexual é o ascósporo. Alguns estados perfeitos têm ascósporos bicelulares e são alocados ao gênero Nectria. Cada célula de um ascósporo bicelular é uninucleada e ambos núcleos são geneticamente idênticos. Outros estados perfeitos, como é o caso em Gibberella, formam ascósporos multicelulares.

Uma cultura de Fusarium recém isolada da natureza deve-se manter inalterada por repetidas subculturas em ágar, podendo mudar sua morfologia gradualmente ou ainda produzir repentinamente setores de crescimento radicalmente diferente na aparência do parental. Essa variabilidade morfológica tem gerado uma certa controvérsia na taxonomia e classificação das espécies de Fusarium (Puhalla, 1981; Oliveira \& Costa, 2002; Geiser et al., 2004).

A taxonomia do gênero Fusarium não está bem estabelecida, chegando a ser confusa (Duggal et al., 1997; Leslie et al., 2001; Sanabria et al., 2002). Inúmeros fatores, incluindo a perda da clara distinção das espécies através de características morfológicas, levando a conceitos que são amplos e juntamente com a variação e mutação dentro da cultura tem conspirado para criar um sistema taxonômico que não reflete a diversidade das espécies. O resultado dessa confusão é uma inconsistente aplicação de nomes de espécies para isolados patogênicos e toxigênicos (Geiser et al., 2004). Muitos isolados de Fusarium estudados por toxicologistas e fitopatologistas nas primeiras décadas do século 20, foram inicialmente identificados incorretamente usando 
simplificados sistemas morfológicos e em muitas espécies de Fusarium. Espécies que, há pouco tempo, foram identificadas usando métodos filogenéticos, certamente não seriam identificadas se fosse utilizado o método convencional de características morfológicas (Aoki, et al., 2003).

Devido à plasticidade e variações de características fenotípicas encontradas neste fungo, a taxonomia baseada somente em conceitos morfológicos não é confiável (Snyder \& Hansen, 1953; Taylor et al., 2001; Summerell \& Leslie, 2003), uma vez que algumas espécies de Cylindrocarpon spp. e Acremonium spp também produzem conídios multicelulares fusiformes, semelhantes aos produzidos pelas espécies de Fusarium. Claramente, uma investigação da variação em Fusarium é essencial para uma caracterização do gênero (Godoy \& Colombo, 2004). Ainda neste aspecto, dentro do gênero Fusarium, há uma série de variações de características morfológicas e patogênicas, resultando em uma classificação complexa dividida em seções, formae speciales e raças (Oliveira \& Costa, 2002).

O conceito formae speciales foi aplicado por Snyder \& Hansen (1953) para reconhecer isolados patogênicos que foram morfologicamente semelhantes a isolados saprofíticos de mesma espécie, mas que diferenciam em sua habilidade para parasitar hospedeiros específicos. Isolados patogênicos de $F$. oxysporum estão classificados dentro de mais de 120 formae speciales e raças. 


\subsubsection{Métodos de Controle}

Os métodos mais utilizados no controle de isolados patogênicos de Fusarium incluem: a utilização de cultivares resistentes, desinfestação do solo com fungicida químico e rotação de cultura utilizando plantas não hospedeiras (Agrios, 1988). A utilização de cultivares resistentes seria uma grande alternativa, porém, dificuldades como a identificação de genes de resistência ou a habilidade de adaptação dos patógenos a novos genótipos, pode tornar a resistência uma solução temporária (Sutton, 2000). Além disso, o controle químico do Fusarium spp. não é totalmente eficiente, uma vez que o patógeno penetra no tecido vascular da planta. Ainda, os insumos químicos têm causado impactos negativos nos mais diferentes compartimentos dos ecossistemas, representados por contaminação das águas, resíduos químicos no solo, efeitos nos microrganismos e danos à saúde humana (Tokeshi 2000). A medida de rotação de cultura seria de pouca eficiência já que este patógeno é um fungo de solo, capaz de sobreviver nos restos de cultura e apresenta várias espécies vegetais como hospedeiras (Sutton, 2000).

Diante disso, uma alternativa para controle de doenças causadas pelo Fusarium é a utilização de isolados não patogênicos deste fungo. Isolados não patogênicos de Fusarium obtidos de solo têm sido testadas como agentes biocontroladores de doenças causadas por este fungo, como a Murcha do Fusarium (Toyota et al., 1995; Guini et al., 2000; Salerno et al., 2000; Edel et al., 2001; Benhamou et al., 2002). Nelson et al. (1981) relatou que solos 
supressivos para a Murcha de Fusarium, suportavam grandes populações de espécies não patogênicas. Isolados de $F$. oxysporum e $F$. solani foram muito mais eficientes no estabelecimento de supressão do solo que outras espécies de fungo. Embora isolados obtidos do solo sejam capazes de controlar as doenças causadas por Fusarium, isolados endofíticos de F. oxysporum que foram isoladas de caule de plantas sadias também se mostraram eficientes para o biocontrole (Fravel et al., 2002).

Apesar de que o uso de isolados não patogênicos de Fusarium no controle biológico ter sido reportado, poucos estudos foram realizados com a finalidade de conhecer a variabilidade genética neste grupo, bem como comparar com a variabilidade de isolados não patogênicos. Este estudo seria de fundamental importância para maximizar a consistência e eficácia do biocontrole. Neste contexto é de extrema importância o conhecimento da estrutura populacional deste grupo e entender a variabilidade genética presente neste fungo. Atualmente diversas metodologias são adotadas visando acessar e estudar a variabilidade genética de fungos sendo que a maior parte é baseada na utilização de marcadores moleculares.

\subsection{Análise da Variabilidade Genética por Marcadores Moleculares}

Nas últimas décadas várias metodologias moleculares têm sido desenvolvidas contribuindo significativamente para um grande avanço do conhecimento sobre a variabilidade genética de microrganismos. Dentre as 
técnicas mais utilizadas destacam-se: a) RFLP (Restriction Fragment Length Polymorphism); b) RAPD (Random Amplified Polymorphic DNA); c) AFLP (Amplified Fragment Length Polymorphism) ; d) seqüências de subunidades do rDNA; e) ARDRA (Amplified Ribosomal DNA Restriction Analysis); f) RISA (Ribosomal Intergenic Spacer Analysis); g) DGGE (Denaturing Gradient Gel Electrophoresis) (Van Elsas et al., 1998; McDonald, 1997; Amicucci et al., 2001; Pennanen et al., 2001; Taylor et al., 2001; Oliveira \& Costa, 2002; Marshall et al., 2003; Fagbola \& Abang, 2004). Entretanto, exista um grande número de técnicas, que revelam polimorfismo de DNA, é importante considerar o tipo de organismo em estudo.

\subsubsection{Variabilidade Genética por Seqüenciamento do rDNA e ARDRA}

Estudos moleculares envolvendo o cluster gênico do rDNA (DNA ribossomal) (ITS1, 5.8S e ITS2) têm facilitado na identificação de fungos e muito contribuído para expandir o conhecimento da diversidade microbiana nos últimos anos (Nazar et al., 1991; Bryan, et al., 1995; Larena et al., 1999; Skouboe, et al., 1999; Hermosa et al., 2000; Pianzzola et al., 2004).

O rDNA está presente em todos os organismos, evoluem rapidamente e portanto são apropriadas para discriminar espécies relacionadas ou até mesmo variedades de uma mesma espécie. As regiões ITS são flanqueadas por segmentos conservados (genes $18 \mathrm{~S}, 5.8 \mathrm{~S}$ e $28 \mathrm{~S}$ ). Estas regiões conservadas carreiam a informação sobre a filogenia e o nível taxonômico, uma vez que têm 
evoluído lentamente e são altamente semelhantes dentro de diferentes taxons, enquanto que as regiões variáveis, os ITS, apresentam muitas mutações durante o processo de evolução podendo ser mais utilizado para a classificação intraespecífica (Fungaro, 2000). O fato das regiões ITS serem relativamente curtas (500 a $800 \mathrm{pb})$ e aparecerem em grande número de cópias no genoma, permite que sejam amplificadas e sequenciadas com facilidade (Carbone \& Kohn, 1997 Cooke \& Duncan, 1997; Skouboe et al., 1999; Leal-Junior, 2002). Como conseqüência disso, é grande o número de seqüências ITS de diferentes fungos que estão atualmente disponíveis nos bancos de dados de seqüências de nucleotídeos. A utilização de programas computacionais, que permitem a comparação destas seqüências de organismos alvos e não alvos, permite definir regiões apropriadas para a síntese de primers utilizados para detectar uma determinada espécie de fungo (Fungaro, 2000).

Outra metodologia aplicada ao estudo da diversidade de fungos é a técnica de ARDRA (Amplified Ribosomal DNA Restriction Analysis), que consiste na amplificação e posterior digestão da região ITS do rDNA com enzimas de restrição. $\mathrm{O}$ valor deste método está na sua rapidez e habilidade para avaliar diferenças entre grupos filogenéticos, efetuando análises em vários níveis de classificação, inclusive em estudos de evolução, gerando novos marcadores para estudos de genética de populações (Jorgensen \& Cluster, 1989, Abd-Elsalam et al., 2003) em estudos da diversidade microbiana associada a vegetais ou a diferentes solos (Ovreas \& Torsvik, 1998; Hermosa et al., 2000; Chelius \& Triplett, 2001; Kuklinsky-Sobral, 2003), em análises da 
diversidade genética de isolados fitopatogênicos (Moricca, et al., 1998; Oliveira \& Costa, 2002), entre outros.

Desta forma, tais técnicas mostram-se de extrema utilidade em estudos de variabilidade genética de Fusarium spp. e sobretudo capaz para elucidar controvérsias quanto a classificação taxonômica dentro de formae speciales, ampliando o nível de conhecimento da diversidade, estrutura destas comunidades fúngicas, conduzindo à um melhor entendimento de seu no papel no ecossistema.

\subsubsection{Variabilidade Genética via RAPD}

A técnica de RAPD é baseada no princípio da PCR (Polymerase Chain Reaction) descrita por Williams et al. (1990) e Welsh \& McClelland (1990). Esta técnica envolve a amplificação de regiões anônimas dispersas pelo genoma, onde a estratégia é a utilização de iniciadores ou primers curtos e aleatórios que se anelam a diferentes locais no DNA genômico (Fungaro, 2000). Os marcadores de RAPD permitem gerar uma grande quantidade de informações sobre a diversidade genética. Em geral, os dados são obtidos na forma de matriz composta por um certo número de genótipos que podem ser variedades, isolados ou clones, genotipados para dezenas ou centenas de marcadores RAPD, obtidos com um ou mais primers. O número de marcadores permite uma análise extensiva dos genomas de interesse diretamente da molécula de DNA, conseqüentemente sem influência do ambiente (Ferreira \& Grattapaglia, 1996). 
Esta técnica tem a vantagem por ser rápida e de baixo custo, permitindo uma alta densidade de mapeamento, abrangendo todo o genoma, sem envolver hibridização ou radioatividade. Além disso, não há necessidade do conhecimento prévio das seqüências de nucleotídeos que flanqueiam a região de DNA de interesse para a construção de primers para a amplificação (Michelmore et al., 1991).

Desde sua descrição o uso de marcadores RAPD tem tido uma difusão extremamente rápida, sendo extremamente útil para estudos de identificação taxonômica (Liu et al., 1995; Yuan et al., 1995; Guzmán et al.,1999), caracterização de raças (Guthrie et al., 1992; Jiménez-Gasco et al., 2001), analise de variabilidade da virulência em fungos fitopatogênicos (Cooke et al., 1996; Fernández \& Hanlin, 1996; Mostafa et al., 2002; Araya et al., 2004; Belabid et al., 2004) e variabilidade inter e intraespecífica de populações de diferentes regiões (Liew \& Irwin, 1994; Guzmán et al., 1995; Jamil et al., 2000; Roy et al., 2000).

A variabilidade intraespecífica de isolados de Bipolaris sorokiniana, coletados de diferentes regiões do Brasil, foi avaliada por meio da técnica de RAPD por Oliveira \& Costa (2002), que observaram alto nível de variabilidade entre os isolados.

Silva-Mann et al. (2002) associaram informações de teste de patogenicidade com marcadores bioquímicos e moleculares de DNA/RAPD, visando a identificação e diferenciação do complexo Colletotrichum. Foram utilizados dez isolados, sendo três classificados como causadores de 
antracnose e sete de ramulose, pelo teste de patogenicidade. Os marcadores bioquímicos não se mostraram eficientes para a distinção dos isolados causadores da ramulose e da antracnose. $\mathrm{Na}$ análise de RAPD, o valor de similaridade encontrado para os dois grupos foi de $51,7 \%$, confirmando a potencialidade da técnica para diferenciar tais fungos.

Neste contexto, diversos trabalhos tem sido realizados com RAPD no gênero Fusarium envolvendo análise da variabilidade, mapeamento genético, diferenciação de isolados, estudo de populações, dentre outros. Bentley et al. (1995), utilizaram a técnica de RAPD em estudos com $F$. oxysporum f. sp. cubense para avaliar a variação genética de uma coleção mundial de isolados das raças 1, 2, 4 e 11 com diferentes grupos de compatibilidade vegetativa (VCGs). Por meio desta técnica foi possível subdividir os isolados de $F$. oxysporum f. sp. cubense em dois grupos, não havendo contudo, correlação entre o padrão de RAPD e a raça. A comparação dos padrões de bandas do RAPD foi semelhante ao agrupamento obtido pelos VCGs, mostrando que a identificação por raças pode não expressar uma relação filogenética.

Marcadores de RAPD foram utilizados também para discriminar formas patogênicas de F. luffae e F. oxysporum f. sp. cucumerinun (Wang et al., 2001). Por meio do perfil de RAPD de 13 isolados de $F$. oxysporum foram selecionadas bandas específicas de DNA que podem ser utilizadas como sondas para diferenciar estas formas patogênicas de Fusarium. Além disso, Kelly et al. (1994) caracterizaram patótipos de F. oxysporum. Os autores analisaram 63 isolados de $F$. oxysporum f. sp. ciceri e de 11 isolados de outras 
espécies de Fusarium, permitindo a separação dos isolados de $F$. oxysporum f. sp. ciceris em dois grupos distintos, os quais foram distintos de outros isolados pertencentes a outras formae speciales. Yli-Mattila et al. (1996) analisaram 33 isolados de $F$. avenaceum baseado em análises de RAPD e isoenzimas. Entre oito enzimas analisadas, foi detectado polimorfismo enzimático em cinco enzimas. Esses polimorfismos puderam ser agrupados em 20 diferentes fenótipos eletroforéticos e em três grupos principais com um nível de similaridade de $70 \%$. As análises de RAPD diferenciaram todos os isolados de F. avenaceum onde os fenótipos resultantes dessas análises distinguiram os isolados em cinco grupos principais ao nível de $55 \%$ de similaridade. Esses grupos tiveram similaridade com os principais grupos das análises isoenzimáticas.

O RAPD também tem sido utilizado para distinguir isolados de diferentes espécies de Fusarium. Amoah et al. (1995) determinaram as características genéticas dos isolados de $F$. moniliforme $(=F$. verticillioides) coletados de milho, arroz e sorgo de diferentes regiões de Gana, usando as técnicas de RAPD e RFLP. Hering \& Niremberg (1995) utilizaram a técnica de RAPD para o estudo de populações do gênero Fusarium. Eles obtiveram padrões informativos típicos para populações de $F$. sambucin, $F$. torulosum e $F$. venenatum utilizando 10 oligonucleotídeos arbitrários e seqüências repetitivas simples [M13, (GACA) 4 como oligonucleotídeos simples.

Pasquali et al. (2003) avaliaram 10 novos isolados patogênicos de $F$. oxysporum obtidos de crisântemo, utilizando-se da técnica de RAPD. Para 
tanto, representantes das formae speciales de $F$. oxysporum basilici, chrysanthemi, cyclaminis, dianthi, gadioli, lilii, lycopersici, melonis, pisi, radicislycopersici, tracheiphilum juntamente com um isolado não patogênico de $F$. oxysporum, foram incluídos nesta análise. Uma alta similaridade foi encontrada entre os novos isolados obtidos de crisântemo. Estes isolados também mostraram similaridade com representantes da forma speciales chrysanthemi, com exceção de um único isolado destes testados, que se juntou a um grupo formado por representantes da formae speciales tracheiphilum.

Conforme observado nesta revisão, estudos envolvendo marcadores RAPD têm sido inúmeros reforçando assim a grande aplicabilidade desta técnica. Entretanto alguns poucos trabalhos têm sido desenvolvidos comparando isolados patogênicas e não patogênicas de Fusarium. Por exemplo, Wright et al. (1996) selecionaram para a patogenicidade, agrupamento de compatibilidade vegetativa e padrões de RAPD, isolados de $F$. oxysporum coletados de cravos sem sintomas de diversas propriedades da Austrália. Da coleção australiana de 82 isolados foram separados em 23 grupos diferentes de compatibilidade vegetativa. Dos 69 isolados testados para a patogenicidade, 24 foram patogênicos ao cravo, enquanto que os 45 isolados remanescentes foram não patogênicos. A análise de RAPD revelou dois padrões distintos de bandas que puderam distinguir os isolados patogênicos dos não patogênicos.

Neste contexto, Nelson et al. (1997) utilizaram a técnica de RAPD para estudos de caracterização genética de isolados de $F$. oxysporum que foram 
isoladas de Erythroxylum coca var. coca no Peru. Foram obtidos 200 isolados, sendo que 187 foram identificados como sendo F. oxysporum. Por meio de análises de patogenicidade 147 isolados mostraram ser patogênicos à coca. Marcadores RAPD puderam facilmente distinguir isolados de $F$. oxysporum f. sp. erythroxyli de isolados não patogênicos de F. oxysporum. Moller et al. (1999) utilizaram PCR para identificar isolados de Giberella fujikuroi usando pares de primers baseado em seqüências de fragmentos obtidos por RAPD específicos para Fusarium moniliforme e Fusarium subglutinans.

Pamphile \& Azevedo, (2002) foram os primeiros a utilizar a técnica de RAPD em estudos de isolados endofíticos de $F$. oxysporum obtidos de sementes de milho. Vinte e um isolados de $F$. verticillioides (=F. moniliforme) coletados de sementes de milho sadias foram utilizados para avaliar a existência de interação entre a variabilidade genética, o sitio de isolamento e a população de milho hospedeira. Segundo os autores, por meio de marcadores RAPD, foi possível separar isolados endofíticos de $F$. verticillioides de diferentes genótipos de sementes de milho, mostrando que existe uma grande associação entre eles, o qual pode ser específica para o genótipo da planta hospedeira.

Estes poucos relatos encontrados na literatura com relação à variabilidade genética de isolados patogênicos e não patogênicos de Fusarium utilizando a técnica de RAPD, reforçam ainda mais a necessidade de ampliar os estudos desta natureza. Além disso, estudos envolvendo isolados endofíticos de Fusarium têm sido incipientes e ainda incompletos, apesar de existir razões para que estudos com estes isolados sejam aprofundados, visto que a falta de 
informações para elucidar a base biológica das interações dos isolados patogênicos com a planta dificulta a utilização de isolados endofíticos como agentes de controle biológico e promoção de crescimento vegetal. Outro ponto a ser ressaltado é que a maioria dos estudos de Fusarium spp. encontrados na literatura é realizado em países de clima temperado, que por vezes não podem ser aplicados nas condições brasileiras, tendo em vista a grande diversidade microbiana observada em regiões tropicais. Dessa forma, torna-se evidente a necessidade de um melhor conhecimento deste tipo de estudo nas condições brasileiras.

\subsection{Interação Fungo/Planta}

As interações entre as plantas e os fungos são de extremo interesse para a humanidade, uma vez que grande parte da economia mundial tem por base a utilização de espécies vegetais, as quais podem sofrer sérios danos em virtude do ataque de fungos patogênicos (Barbieri \& Carvalho, 2001).

Das espécies de fungos conhecidas, aproximadamente $10 \%$, podem causar doenças em plantas, sendo que alguns destes fungos são considerados como parasitas obrigatórios, estando associados ao hospedeiro durante todo seu ciclo de vida. Os fungos saprofíticos podem proliferar tanto em tecido vivo como em restos de material vegetal morto, enquanto que os parasitas não obrigatórios dependem da planta em alguns estágios de seu ciclo de vida (Burdon \& Silk, 1997). Estas diferenças no estilo de vida requerem adaptações 
específicas ao hospedeiro. Considerando que fungos patogênicos necessitam apenas dominar o sistema de defesa do hospedeiro e podem fazer isso pela morte de células do hospedeiro por meio da produção de toxinas específicas e/ou por secreção de enzimas líticas. Dessa forma, acredita-se que a interação entre fungos e a planta hospedeira tem necessariamente um ajuste fino por meio de sinais das duas partes (Chasan, 1994). Fungos patogênicos biotróficos obrigatórios, como ferrugens e míldios, vivem em íntimo contato com seu hospedeiro sem induzir morte de células e respostas de defesa enquanto que patógenos biotróficos facultativos podem ser cultivados em condições axênicas mas, alguns necessitam íntimo contato com a planta hospedeira para concluir seu ciclo de vida sexual Já os fungos hemibiotróficos podem completar seu ciclo de vida fora da planta, mas desenvolvem estruturas especializadas durante a infecção que não são observadas durante crescimento axênico (Kahmann \& Basse, 2001).

De modo geral, fungos patogênicos compreendem um amplo e heterogêneo grupo de microrganismos que ocupam posições de grande importância tanto na agricultura como nas comunidades naturais da planta. Estes mostram uma enorme diversidade dentro da sua estratégia de vida e no modo pelo qual estes microrganismos interagem com seu hospedeiro. As estratégias de interação estabelecidas entre patógeno-hospedeiro variam de infecções que podem levar o hospedeiro rapidamente a morte para uma discreta lesão cujo efeito individual é limitado (Burdon \& Silk, 1997). 
A colonização de fungos patogênicos na planta hospedeira ocorre por meio do desenvolvimento de haustórios, os quais penetram na célula vegetal e absorvem os nutrientes da planta. Além disso, a presença dessas estruturas pode direcionar o metabolismo da planta na direção dos requerimentos nutricionais do patógeno (Agrios, 1997). Durante o desenvolvimento da patogênese na interação entre fungos e plantas são expressos vários genes envolvidos na formação de estruturas de infecção e síntese de enzimas para degradação da parede vegetal do hospedeiro. Estes genes podem se expressar durante as fases de contato inicial com o hospedeiro, como resposta à defesa da planta, ou na fase de necrose (Kahmann \& Basse, 2001). O fungo Colletotrichum gloeosporioides, por exemplo, quando em contato com a superfície do hospedeiro expressa os genes cap20,22, os quais atuam na formação do apressório (Kolattukudy et al., 1995); Já F. oxysporum f. sp. lycopersici em estágios avançados de infecção expressa o gene pl1 (pectate lyase) (Huertas-González et al., 1999) que pode atuar na degradação da parede do hospedeiro, facilitando a sua penetração.

Grande parte dos fungos, como os endófitos, estabelece íntimas relações de simbiose com as plantas. Microrganismos endofíticos são definidos como aqueles que vivem parte ou todo seu ciclo de vida no interior de órgãos ou tecidos de plantas e não causam danos aparentes ao hospedeiro (Carroll, 1986; Petrini, 1991; Azevedo, 1998; Sturz et al., 2000). Recentemente esta definição foi ampliada para microrganismos que podem habitar o interior de tecidos 
vegetais sem causar danos ao hospedeiro ou formar estruturas externas visíveis (Azevedo et al., 2000).

O ciclo de vida dos fungos associados às plantas inicia com a germinação do esporo seguido do crescimento da hifa na folha ou superfície de raiz. A penetração de fungos endofíticos na planta pode ocorrer por aberturas naturais do hospedeiro como estômatos (Wagner \& Lewis, 2000), e também tem sido observado que fungos endofíticos como Piriformospora indica podem produzir apressórios que favorecem a penetração nos tecidos da planta hospedeira (Varma et al., 1999). Entretanto, outros fungos como Beauveria bassiana parecem não precisar de apressórios para penetrar na planta hospedeira, pois, foi observado que esporos de $B$. bassiana germinam sobre a planta de milho e crescem de forma aleatória nesta superfície, onde posteriormente podem penetrar via estômatos ou por entre as células da epiderme através da cutícula. Nesta penetração, deve estar envolvida a ocorrência de ação enzimática a partir das hifas de $B$. bassiana sobre a cutícula dos tecidos do hospedeiro, permitindo assim a sua penetração (Wagner \& Lewis, 2000). Segundo os autores, após penetração, o endófito pode se movimentar de forma passiva no interior do hospedeiro, por meio do xilema sem causar qualquer sintoma de patogênese. 


\subsubsection{Microrganismos endofíticos no controle de patógenos de plantas}

Fungos endofíticos colonizam um nicho ecológico semelhante aquele ocupado por fitopatógenos, favorecendo a sua utilização como agentes de controle biológico de doenças, sendo esta potencialidade objeto de estudo para diversas culturas vegetais. São vários os mecanismos de atuação do endófito sobre o patógeno. Neste aspecto, o controle de doenças por microrganismos endofíticos pode ocorrer principalmente devido à atuação direta do endófito sobre o patógeno (Barka et al., 2002; Pan et al., 1997), por antibiose, (Marcon, 2002; Sturz \& Matheson, 1996; Assis et al., 1998; Benhamou \& Brodeur, 2000) e por indução de resistência sistêmica (Krishnamurthy \& Gnanamanickam, 1997; M'piga et al., 1997; Raupach \& Kloepper, 1998; Benhamou, 2004).

Foi verificado que uma linhagem da bactéria Burkholderia cepacia, isolada de aspargos, coloniza os espaços intercelulares de raízes de bananeira e está associada ao controle de F. oxysporum f. sp. cubense neste hospedeiro (Pan et al., 1997). Segundo os autores, foi observado, in vitro, que esta bactéria endofítica coloniza a superfície da hifa e macrósporos deste fitopatógeno, causando protuberâncias anormais nas hifas que resultam na deformação do micélio. Bacon \& Hinton (2002) verificaram que Bacillus mojavensis coloniza endofiticamente plantas de milho e apresenta atividade antagonista a $F$. moniliforme, um patógeno produtor de micotoxina no milho, mostrando que esta é uma eficiente estratégia para o controle de microrganismos prejudiciais em plantas de interesse agrícola. 
Em estudo semelhante realizado em uma planta medicinal, a Artemisia annua, produtora de um antimalárico, foram analisados 39 fungos endofíticos, sendo observado que 21 isolados produziram in vitro compostos antagônicos a G. graminis var. tritici, Rhizoctonia cerealis, Helminthosporium sativum, F. graminearum, Gerlachia nivalis e Phytophthora capsici, mostrando o potencial destes endófitos ou de produtos produzidos por eles para o controle destes patógenos (Hong et al., 2001). Em outro trabalho, foi observado que os fungos endofíticos Epichloe festucae e Neotyphodium tembladerae sintetizam compostos inibidores de Cryphonectria parasitica, sendo estes compostos principalmente derivados de indol, sesquiterpenos e diacetamida (Qin et al., 2003). Os autores sugerem que estes compostos podem atuar sinergisticamente para a inibição de fungos que poderiam competir com os endófitos.

O controle biológico de doenças e pragas de culturas de interesse, utilizando microrganismos endofíticos, pode ser realizado de forma indireta. Neste caso, o endófito não atua diretamente sobre o patógeno, mas induz uma resposta da planta, ativando o sistema de defesa contra patógenos. A indução da resistência sistêmica está associada a alterações bioquímicas e estruturais na planta hospedeira, as quais afetam adversamente o crescimento $\mathrm{e}$ desenvolvimento do patógeno (Sharma \& Nowak, 1998; Duijff et al., 1997; M'piga et al., 1997). Em ervilha foi observado que a inoculação prévia com um isolado endofítico do fungo $F$. oxysporum protege plântulas contra o ataque de isolados patogênicos de F. oxysporum f. sp. pisi (Benhamou \& Garand, 2001). 
Os autores observaram que a colonização de plântulas de ervilha pelo isolado não patogênico resultou em uma maior deposição de parede e de matéria eletro-opaca em volta da hifa do patógeno ou do xilema de plântulas não infectadas pelo patógeno. Estes resultados sugerem que a raiz da planta hospedeira foi induzida a ativar o seu sistema de defesa por meio de uma rápida estimulação de uma resposta em cascata e não específica.

Estudos de análise citológica, feitos por Benhamou \& Garand (2001), com o isolado não patogênico de $F$. oxysporum (Fo47) verificaram que este endófito induz uma série de mecanismos de defesa em células de tecidos da raiz de ervilha. As células invadidas pelo endófito sofreram uma série de alterações, entre elas a deposição de um material opaco na parede celular e vasos do xilema, dificultando a entrada de patógenos nos tecidos do hospedeiro, sendo por isso este isolado endofítico considerado um potencial agente para o biocontrole de doenças de raiz.

Em repolho, a inoculação do fungo endofítico Heteroconium chaetospira reduziu em até $67 \%$ os sintomas causados pelo patógeno Verticillium (Narisawa et al., 2000). Este endófito coloniza a planta hospedeira devido a formação de apressórios e subsequente colonização intracelular. Segundo os autores, $H$. chaetospira coloniza 18 espécies de plantas hospedeiras, mostrando ser um potencial agente de controle biológico de doenças causadas por Verticillium. Em pesquisa mais recente, Narisawa et al. (2002), obtiveram 123 fungos isolados de raízes de berinjela, melão, morango e repolho e 11 deles foram reintroduzidos em plântulas de berinjela suprimindo quase que completamente 
os efeitos de $V$. dahliae, também inoculado nas plântulas. Embora os mecanismos deste controle não sejam conhecidos, sem dúvida, os resultados indicaram o potencial do processo no controle biológico desse patógeno.

Associações de plantas com endófitos vêm adquirindo importância crescente no biocontrole de fitopatógenos. No entanto os mecanismos envolvidos neste controle são desconhecidos. Portanto a utilização de fungos endofíticos irá depender de um prévio conhecimento sobre aspectos biológicos, genéticos e fisiológicos de interação endófito-planta-patógeno. Dessa forma, torna-se evidente a necessidade de que estudos como estes sejam conduzidos, uma vez que os mesmos poderão possibilitar em uma melhor utilização prática destes microrganismos. 


\section{MATERIAL E MÉTODOS}

\subsection{Material biológico}

Foram utilizados isolados endofíticos e patogênicos de Fusarium spp. obtidos de diferentes hospedeiros (soja, cacau, tomate, algodão, milho, entre outras), bem como isolados obtidos do solo. Estes isolados pertencem à coleção do Laboratório de Genética de Microrganismos Prof. João Lúcio de Azevedo do Departamento de Genética (ESALQ/USP, Piracicaba, SP) e foram gentilmente cedidos por outros pesquisadores (Tabela 1) ou obtidos em outros projetos no laboratório. Os fungos foram cultivados em meio de cultura BDA (Batata Dextrose Agar) a $28^{\circ} \mathrm{C}$.

Tabela 1. Isolados, hospedeiros, patogenicidade e procedência dos isolados de Fusarium spp. utilizados no presente trabalho

\begin{tabular}{ccll}
\hline N. Isolados & Hospedeiro & Patogenicidade & Procedência \\
\hline 21 & Soja & Endofítico & Esalq - Piracicaba - SP \\
1 & Soja & Patogênico & Embrapa - Jaguariúna - SP \\
3 & Soja & Patogênico & Embrapa - Londrina - PR \\
18 & Cacau & Endofítico & Itabuna - Bahia
\end{tabular}




\begin{tabular}{ccll}
\hline N. Isolados & Hospedeiro & Patogenicidade & \multicolumn{1}{c}{ Procedência } \\
\hline 6 & Cana & Patogênico & Copersucar - SP \\
1 & Pupunha & Endofítico & Esalq - Piracicaba - SP \\
1 & Girassol & Patogênico & Recife - PE \\
1 & Algodão & Patogênico & Recife - PE \\
1 & Milho & Patogênico & Recife - PE \\
2 & Mandioca & Patogênico & Recife - PE \\
1 & Trigo & Patogênico & Embrapa - Jaguariúna - SP \\
2 & Cactus & Endofítico & Embrapa - Jaguariúna - SP \\
2 & Tomate & Patogênico & Dijon- França \\
2 & Melão & Patogênico & Dijon - França \\
8 & Rabanete & Patogênico & Dijon - França \\
3 & Solo & - & Dijon - França \\
1 & Solo & - & IOC - São Paulo \\
6 & Tomate & Patogênico & Embrapa - Jaguariúna - SP \\
& Desconhecido & Endofítico & Embrapa - Jaguariúna - SP \\
\hline & & Tortal de 83 Isolados & \\
\hline & & & \\
\hline & & & \\
\hline
\end{tabular}

IOC: Instituto Osvaldo Cruz

\subsection{Meios de Cultura e Soluções}

\subsubsection{Meio Batata Dextrose Ágar (BDA)}

Batata

Ágar

Glicose

$\mathrm{H}_{2} \mathrm{O}$ destilada
$200,0 \mathrm{~g}$

$15,0 \mathrm{~g}$

$20,0 \mathrm{~g}$

$1000 \mathrm{~mL}$ 
A batata foi cozida por 30 minutos em $200 \mathrm{~mL}$ de água e filtrada em gaze. $\mathrm{O} \mathrm{pH}$ foi ajustado para $6,8 \mathrm{com} \mathrm{NaOH} 1 \mathrm{~N}$.

\subsubsection{Meio BDA líquido}

Preparado segundo o item 3.2.1 sem ser adicionado ágar.

\subsubsection{Tampão de corrida TAE $50 \mathrm{x}$}

$\begin{array}{ll}\text { Trizma-Base } & 242,0 \mathrm{~g} \\ \text { Ácido Acético Glacial } & 57,1 \mathrm{~mL} \\ \text { EDTA 0,5M pH 8,0 } & 100 \mathrm{~mL} \\ \mathrm{H}_{2} \mathrm{O} \text { destilada } & 1000 \mathrm{~mL}\end{array}$

A solução foi autoclavada e mantida à temperatura ambiente. No momento do uso foram feitas as diluições apropriadas.

3.2.4 Solução de brometo de etídio (Sambrook et al. 1989)

$\begin{array}{ll}\text { Brometo de etídio } & 0,01 \mathrm{~g} \\ \mathrm{H}_{2} \mathrm{O} \text { destilada } & 10 \mathrm{~mL}\end{array}$


A solução foi agitada por várias horas e estocada a temperatura ambiente. No momento do uso, $5 \mu \mathrm{L}$ desta solução foram adicionados a $100 \mathrm{~mL}$ de TAE 1x.

\subsubsection{Solução Clorofil}

Misturou-se clorofórmio e álcool isoamílico na proporção 24:1.

\subsubsection{Solução Clorofane}

Misturou-se um volume de fenol com um volume de Clorofil.

\subsubsection{Fenol saturado (Sambrook et al. 1989)}

Foram dissolvidos em banho-maria $50 \mathrm{~g}$ de fenol cristalizado e adicionado um volume de tampão Tris-HCl 1,0M (pH 8,0). Após agitação por um período de aproximadamente 1 hora, foi retirada a fase aquosa, adicionado um volume de tampão Tris- $\mathrm{HCl} 0,1 \mathrm{M}(\mathrm{pH} 8,0)$ e colocado sob agitação. Este procedimento se repetiu até que o $\mathrm{pH}$ do fenol chegasse a 8,0. Em seguida, após a retirada da fase aquosa foram adicionados $1 / 10$ do volume final de Tris- $\mathrm{HCl} 0,1 \mathrm{M}(\mathrm{pH} 8,0)$. O fenol foi estocado em frasco escuro a $-20^{\circ} \mathrm{C}$. 


\subsubsection{Solução estoque Tris-HCI 1M pH 8,0}

Trizma-Base

$\mathrm{H}_{2} \mathrm{O}$ destilada

$\mathrm{O} \mathrm{pH}$ foi ajustado para $8,0 \mathrm{com} \mathrm{HCl}$ concentrado. A solução foi
$121,0 \mathrm{~g}$

$1000 \mathrm{~mL}$ autoclavada e mantida a $4^{\circ} \mathrm{C}$.

\subsubsection{Solução EDTA 0,5M pH 8,0}

EDTA

$\mathrm{H}_{2} \mathrm{O}$ destilada

$\mathrm{O} \mathrm{pH}$ foi ajustado para 8,0 com pastilhas de $\mathrm{NaOH}$. A solução foi autoclavada e mantida a $4^{\circ} \mathrm{C}$.

\subsubsection{NaCl 5M}

$\mathrm{NaCl}$

$\mathrm{H}_{2} \mathrm{O}$ destilada
$37,22 \mathrm{~g}$

$100 \mathrm{~mL}$

A solução foi autoclavada e mantida a $4^{\circ} \mathrm{C}$.

\subsubsection{NaCl 3M}
$\mathrm{NaCl}$
$17,5 \mathrm{~g}$
$\mathrm{H}_{2} \mathrm{O}$ destilada
$100 \mathrm{~mL}$

A solução foi autoclavada e mantida a $4^{\circ} \mathrm{C}$. 


\subsubsection{Tampão TE}

$\begin{array}{ll}\text { Tris-HCl } 1 \mathrm{M} \mathrm{pH} \mathrm{8,0} & 1 \mathrm{~mL} \\ \text { EDTA 0,5M pH 8,0 } & 0,2 \mathrm{~mL}\end{array}$

O volume foi completado para $100 \mathrm{~mL}$ com $\mathrm{H}_{2} \mathrm{O}$ destilada. A solução foi autoclavada e mantida a $4^{\circ} \mathrm{C}$.

\subsubsection{SDS $10 \%$}

$\begin{array}{ll}\mathrm{NaCl} & 10,0 \mathrm{~g} \\ \mathrm{H}_{2} \mathrm{O} \text { destilada } & 100 \mathrm{~mL}\end{array}$

A solução foi autoclavada e mantida a $4^{\circ} \mathrm{C}$.

\subsubsection{Tampão de amostra $(6 x)$}

$\begin{array}{ll}\text { Azul de bromofenol } & 0,25 \mathrm{~g} \\ \text { Glicose } & 15,0 \mathrm{~g} \\ \mathrm{H}_{2} \mathrm{O} \text { destilada } & 100 \mathrm{~mL}\end{array}$

A solução foi aliquotada e mantida a $4^{\circ} \mathrm{C}$. 
3.2.15 Tampão de extração de DNA de fungos filamentosos (Raeder \& Broda, 1985)

$\begin{array}{lc}\text { Tris- } \mathrm{HCl} 1 \mathrm{M} \mathrm{pH} 8,0 & 2 \mathrm{~mL} \\ \text { EDTA } 0,5 \mathrm{M} \mathrm{pH} 8,0 & 0,5 \mathrm{~mL} \\ \text { SDS } 10 \% & 1 \mathrm{~mL} \\ \mathrm{NaCl} 5 \mathrm{M} & 0,5 \mathrm{~mL} \\ \mathrm{H}_{2} \mathrm{O} \text { destilada } & 6 \mathrm{~mL} \\ \text { O tampão foi preparado no momento do uso. }\end{array}$

\subsubsection{Primers de RAPD}

Foram utilizados primers da Operon Technologies, CA, EUA, que foram diluídos à uma concentração final de $4 \mu \mathrm{M}$ em água Milli $\mathrm{Q}$, usando o peso molecular do primer individual dado pelo fornecedor. Os primers foram mantidos diluídos a $-20^{\circ} \mathrm{C}$.

\subsubsection{Primers da região ITS do rDNA}

Foram utilizados os primers ITS-1 (5'-CTTGGTCATTTAGAGGAAGTAA3') e ITS-4 (5'-CAGACTRTAYATGGTCCAG-3') para a região ITS (Internal Transcribed Spacer) do rDNA. 


\subsubsection{8 d'NTPs}

Cada um dos nucleotídeos vem em uma concentração de 100mM. Para uso, misturou-se partes iguais de modo a obter uma concentração final de $2,5 \mathrm{mM}$ de cada d'NTP. A solução foi mantida a $-20^{\circ} \mathrm{C}$.

\subsection{Obtenção do micélio para a extração do DNA genômico}

Aproximadamente $10^{7}$ conídios foram inoculados em frasco de Erlenmeyer de $500 \mathrm{~mL}$ contendo BDA líquido. Após a inoculação, estes frascos foram mantidos sob agitação de $150 \mathrm{rpm}$ a $28^{\circ}$ por 48 horas. Decorrido este tempo, o micélio foi coletado por filtração e lavado com água destilada.

\subsection{Extração de DNA}

Um grama do micélio foi triturado com nitrogênio líquido até formar um pó, o qual foi transferido imediatamente para um tubo de microcentrífuga. Foi adicionado $1 \mathrm{~mL}$ de tampão de extração para cada grama de micélio. Após a homogeneização, os tubos de microcentrífuga foram incubados por 1 hora a $65^{\circ} \mathrm{C}$. Após o período de incubação foi adicionado um volume da solução de fenol, misturando suavemente as fases e centrifugado a $10.000 \mathrm{rpm}$ por 15 minutos. A fase aquosa foi recuperada e transferida para um novo tubo de 
microcentrífuga e a esta foi adicionado um volume de clorofil. Novamente a solução foi homogeneizada e centrifugada na mesma condição anterior, onde o sobrenadante foi recuperando e transferido para um outro tubo de microcentrífuga. A este foi acrescentado $\mathrm{NaCl} 3 \mathrm{M}$ para uma concentração final de $0,3 \mathrm{M}$. A seguir, foram adicionados dois volumes de etanol resfriado a $-20^{\circ} \mathrm{C}$. Nesta fase foi possível visualizar o DNA precipitado. As amostras novamente foram submetidas a centrifugação a 14.000 rpm por 15 minutos. Após a centrifugação o sobrenadante foi descartado e o precipitado obtido foi lavado com etanol $70 \%$. Em seguida o sobrenadante os tubos foram invertidos até secagem completa do DNA. Este foi ressuspendido em $200 \mu \mathrm{L}$ do tampão TE.

\subsection{Quantificação do DNA}

A concentração de DNA foi estimada por meio de eletroforese em gel de agarose $0,8 \%$, juntamente com o DNA do fago $\lambda$ (Invitrogen) com concentração conhecida. Após eletroforese, o gel foi corado com brometo de etídio, observado sobre transiluminador de ultravioleta e fotodocumentado.

\subsection{Amplificação e seqüenciamento da região ITS do rDNA}

O rDNA (regiões ITS1 + 5,8S + ITS2) foi amplificado usando os oligonucleotídeos iniciadores ITS1 e ITS4 (item 3.2.17). As reações de PCR 
foram realizadas em um termociclador (Perkin-Elmer GeneAmp ${ }^{\circledR}$ PCR System 9700), programado para realizar uma desnaturação inicial de 5 minutos a $94^{\circ} \mathrm{C}$, seguido de 30 ciclos, sendo que cada ciclo consiste de uma etapa de desnaturação (30 segundos a $\left.94^{\circ} \mathrm{C}\right)$, uma etapa de pareamento (30 segundos a $55^{\circ} \mathrm{C}$ ) e uma etapa de alongamento (30 segundos a $72^{\circ} \mathrm{C}$ ) e por fim uma extensão final a $72^{\circ} \mathrm{C}$ por 7 minutos.

Para a amplificação das amostras utilizou-se uma mistura conforme descrito na Tabela 2.

Tabela 2. Componentes da reação de amplificação do DNA de Fusarium spp. e respectivas concentrações utilizadas em uma reação de ITS

\begin{tabular}{lccc}
\hline \multicolumn{1}{c}{ Componentes } & $\begin{array}{c}\text { Concentração } \\
\text { estoque }\end{array}$ & $\begin{array}{c}\text { Volume na } \\
\text { reação }(\mu \mathrm{L})\end{array}$ & $\begin{array}{c}\text { Concentração } \\
\text { final }\end{array}$ \\
\hline Água Milli Q & - & 31,2 & Qsp \\
Tampão & $10 \mathrm{x}$ & 5,0 & $1 \mathrm{x}$ \\
d'NTPs & $2,5 \mathrm{mM}$ & 5,0 & $0,25 \mathrm{mM}$ \\
Primer ITS 1 & $50 \mu \mathrm{M}$ & 1,0 & $0,05 \mathrm{mM}$ \\
Primer ITS 4 & $50 \mu \mathrm{M}$ & 1,0 & $0,05 \mathrm{mM}$ \\
MgCl 2 & $50 \mathrm{mM}$ & 3,0 & $3 \mathrm{mM}$ \\
Taq polimerase (Invitrogen) & $5 \mathrm{U} / \mu \mathrm{L}$ & 0,8 & 2 unidades \\
DNA & $10 \eta \mathrm{\eta g} / \mu \mathrm{L}$ & 3,0 & $30 \eta \mathrm{ng}$ \\
Total & & 50 & \\
\hline
\end{tabular}


Foram misturadas quantidades apropriadas de água Milli $Q$ esterilizada, tampão 10x, d'NTPs, primer e $\mathrm{MgCl}_{2}$ em um único tubo. Foram colocados $45 \mu \mathrm{L}$ dessa solução (para reações com volume final de $50 \mu \mathrm{L}$ ) em cada um dos tubos de microcentrífuga, para a amplificação. Imediatamente após a adição da mistura de reação, foi adicionado $5 \mu \mathrm{L}$ das amostras de DNA previamente diluídas a uma concentração final de $10 \eta \mathrm{g} / \mu \mathrm{L}$. Estes tubos de microcentrífuga foram postos no termociclador para a realização da amplificação.

Após o processo de amplificação $5 \mu \mathrm{L}$ da reação de PCR foram avaliados por eletroforese em gel de agarose 1,3\%, em tampão TAE 1x. O gel foi corado com brometo de etídio, para visualização de um fragmento de aproximadamente $600 \mathrm{pb}$.

Os fragmentos de DNA amplificados foram purificados com o Kit GFX (Amersham Pharmacia) e seqüenciados no laboratório do Dr. Ricardo Harakava (Instituto Biológico, São Paulo). Seqüências de Fusarium spp. obtidas foram analisadas pelo BLASTn contra a base de dados do NCBI (National Center for Biotechnology Information website [http://www.ncbi.nlm.nih.gov/BLAST]). A árvore filogenética foi construída com base nas regiões ITS do rDNA obtidas no seqüenciamento. Para o alinhamento das seqüências foi utilizado o programa Clustal X. Em seguida, as seqüências tiveram suas extremidades cortadas afim que todas apresentassem mesmo número de caracteres, essa edição foi realizada com o programa BioEdit. Finalmente a árvore foi construída utilizando o programa PAUP, considerando máxima parcimônia. 


\section{7 Análise de restrição do produto de amplificação do rDNA (ARDRA)}

Após a obtenção do fragmento da região ITS do rDNA, conforme descrito no item 3.6, estes foram submetidos à análise por meio da técnica de ARDRA (Amplified Ribosomal DNA Restriction Analysis ). Para isso $1 \mu \mathrm{g}$ do fragmento amplificado foi clivado com as enzimas de restrição Hhal, Clal e Mbol, de acordo com as recomendações do fabricante (Invitrogen). Após a digestão, toda a reação foi analisada por eletroforese em gel de agarose 2,0\%, em tampão TAE 1x, juntamente com o marcador de peso molecular DNA Ladder $100 \mathrm{pb}$ (Life Technologies). Em seguida o gel foi corado com brometo de etídio, observado em um transiluminador de UV e fotodocumentado.

\subsection{Amplificação do DNA - RAPD}

Regiões do DNA foram amplificadas por meio da técnica de RAPD, em um termociclador (Perkin-Elmer GeneAmp ${ }^{\circledR}$ PCR System 9700) programado para realizar uma desnaturação inicial de 5 minutos a $94^{\circ} \mathrm{C}$, seguido de 40 ciclos, sendo que cada ciclo consiste de uma etapa de desnaturação (1 minuto a $92^{\circ} \mathrm{C}$ ), uma etapa de anelamento $\left(1\right.$ minuto a $\left.35^{\circ} \mathrm{C}\right)$ e uma etapa de alongamento ( 2 minutos a $72^{\circ} \mathrm{C}$ ) e por fim uma extensão final a $72^{\circ} \mathrm{C}$ por 5 minutos. 
Para a amplificação das amostras foi utilizada uma mistura conforme descrito na Tabela 3. Foram misturadas quantidades apropriadas de água Milli Q esterilizada, tampão 10x, d'NTPs, primer e $\mathrm{MgCl}_{2}$ em um único tubo. Foram colocados $23 \mu \mathrm{L}$ dessa solução (para reações com volume final de $25 \mu \mathrm{L}$ ) em cada um dos tubos de microcentrífuga, para a amplificação. Imediatamente após a adição da mistura de reação, foram adicionados $2 \mu \mathrm{L}$ das amostras de DNA previamente diluídas a uma concentração final de $10 \eta \mathrm{g} / \mu \mathrm{L}$.

Tabela 3. Componentes da reação de amplificação do DNA de Fusarium spp. e respectivas concentrações utilizadas em uma reação de RAPD

\begin{tabular}{lccc}
\hline \multicolumn{1}{c}{ Componentes } & $\begin{array}{c}\text { Concentração } \\
\text { estoque }\end{array}$ & $\begin{array}{c}\text { Volume da } \\
\text { reação }(\mu \mathrm{L})\end{array}$ & $\begin{array}{c}\text { Concentração } \\
\text { final }\end{array}$ \\
\hline Água Milli Q & - & 13,6 & Qsp \\
Tampão & $10 \times$ & 2,5 & $1 \times$ \\
d'NTPs & $2,5 \mathrm{mM}$ & 2,5 & $0,25 \mathrm{mM}$ \\
Primer & $4 \mu \mathrm{M}$ & 2,5 & $0,25 \mathrm{mM}$ \\
MgCl $_{2}$ & $50 \mathrm{mM}$ & 1,5 & $3 \mathrm{mM}$ \\
Taq polimerase (Invitrogen) & $5 \mathrm{U} / \mu \mathrm{L}$ & 0,4 & 2 unidades \\
DNA & $10 \eta \mathrm{g} / \mu \mathrm{L}$ & 2,0 & $20 \eta \mathrm{ng}$ \\
Total & & 25 & \\
\hline
\end{tabular}

Após a amplificação os produtos de RAPD foram analisados eletroforeticamente em gel de agarose 1,3\%, em tampão TAE 1x. O gel foi corado com brometo de etídio, visualizado em transiluminador de UV e fotodocumentado. 


\subsection{Análise computacional dos dados}

Os dados obtidos por amplificação ao acaso do DNA (RAPD) foram analisados pelo programa NTSYS (Numerical Taxonomy and Multivariante Analysis System, versão 2.02). Estes dados foram introduzidos na forma de variáveis binárias, ou seja o número 1 significando presença de banda e o número 0, a ausência. Desta forma, este programa construiu uma matriz de similaridade, utilizando-se do coeficiente de similaridade Jaccard $(\mathbf{a} / \mathbf{a}+\mathbf{b}+\mathbf{c}$, sendo que a significa o número de marcas positivas concordantes e b e c significa o número de marcas discordantes). Estes dados da matriz de similaridade foram então utilizados pelo programa para a construção do dendrograma pelo método UPGMA (Unweighted Pair Group Method Using Arithmetic Average) estabelecendo as relações genéticas entre os diferentes isolados. O consenso do dendrograma foi obtido com número de 1000 réplicas (valores de bootstrap) usando o programa Winboot. O programa agrupou os isolados mostrando o nível de similaridade genética entre eles. 
3.10 Análise da diversidade de isolados de Fusarium utilizando o índice de Shannon

A diversidade genética de isolados patogênicos e não patogênicos (endofíticos e de solo) de Fusarium foi calculada utilizando o índice de diversidade de Shannon, como mostrado abaixo:

Índice de diversidade de Shannon $H^{\prime}$ :

onde, pi é a abundância relativa das $i$ espécies. A análise estatística dos dados

$$
H^{\prime}=-\sum p_{i} \ln p_{i}
$$

foi feita por meio do teste $t$ :

$$
t=\frac{H_{1}^{\prime}-H_{2}^{\prime}}{\left(\operatorname{var} H_{1}^{\prime}+\operatorname{varH}_{2}^{\prime}\right)^{1 / 2}}
$$

onde, $H_{1}^{\prime}$ representa a diversidade da amostra 1 e $\operatorname{Var} H_{1}^{\prime}$ sua variância. Os graus de liberdade podem ser calculados por:

$$
d f=\frac{\left(\operatorname{Var} H_{1}^{\prime}+\operatorname{Var} H_{2}^{\prime}\right)^{2}}{\frac{\left(\operatorname{Var} H_{1}^{\prime}\right)^{2}}{N_{1}}+\frac{\left(\operatorname{Var} H_{2}^{\prime}\right)^{2}}{N_{2}}}
$$




\subsection{Interação fungo-planta}

Abaixo serão descritos os experimentos realizados para avaliar a interação de isolados patogênicos e não patogênicos de Fusarium spp. com a planta.

\subsubsection{Bioensaio - controle biológico}

O bioensaio foi realizado utilizando isolados endofíticos de Fusarium spp. para verificar um possível potencial destes no controle biológico de um isolado patogênico ao tomate. Os isolados utilizados neste experimento estão listados na Tabela 4.

Tabela 4. Isolados de Fusarium utilizadas no ensaio de controle biológico

\begin{tabular}{ccc}
\hline Isolados & Patogenicidade & Hospedeiro \\
\hline Cac12 & Endofítico & Cacau \\
Cac19.4 & Endofítico & Cacau \\
Cac95 & Endofítico & Soja \\
Solo4014 & - & Solo \\
Poty Bot. & Endofítico & Desconhecido \\
Soja69 & Endofítico & Soja \\
PtTom08 & Patogênico & Tomate \\
\hline
\end{tabular}


Neste experimento foi utilizado como planta hospedeira o tomate (Lycopersicun esculentum Mill, cultivar Kada [tipo Santa Cruz]), cultivar susceptível ao Fusarium. O bioensaio foi conduzido em de casa de vegetação, do Campus da Escola Superior de Agricultura "Luiz de Queiroz" - USP, Piracicaba/SP.

Sementes de tomate que foram gentilmente cedidas pelo Prof. Dr. Lázaro Eustáquio Pereira Peres, do Departamento de Ciências Biológicas da ESALQ/USP, foram incubadas em frascos de erlenmeyer em solução aquosa

contendo $10^{8}$ ufc $\mathrm{mL}^{-1}$ de cada isolado, separadamente, por duas horas, a $28^{\circ} \mathrm{C}$ sob agitação. No tratamento controle, as sementes foram incubadas apenas com água. Posteriormente, as sementes foram transferidas para vasos plásticos com capacidade de $2 \mathrm{~kg}$ de solo (3 plantas por vaso, 10 vasos por tratamento).

Cinco dias após o plantio, o isolado patogênico de Fusarium foi inoculado em 5 vasos de cada tratamento à uma concentração de $10^{8}$ ufc $\mathrm{g}^{-1}$ de solo. Decorrido 50 dias, foi realizada a avaliação. Os dados foram submetidos à análise de variância (ANOVA) e quando apropriado, as médias foram comparadas pelo teste de Duncan.

\subsubsection{Reisolamento de Fusarium spp.}

Para o isolamento foram utilizadas três plantas de cada tratamento e seis placas para cada tecido vegetal (caule e raiz). $\mathrm{O}$ isolamento de fungos de caule 
e raiz de tomate seguiu com o processo de desinfecção superficial, no qual as superfícies do caule e raiz foram desinfectados pela seguinte seqüência de imersão: etanol 70\% por 1 min; hipoclorito de sódio (NaOCl) a 3\% (v/v) de cloro ativo acrescido de Tween 20 (1 mL/L) por 1 min.; novamente em etanol 70\% por 1 min. e duas lavagens em água esterilizada. Depois de processados, os caules e raízes foram cortados em pequenos fragmentos de aproximadamente $50 \mathrm{~mm}^{2}$, com auxílio de um estilete sobre placa de Petri esterilizada. Foram transferidos 7 fragmentos vegetais para cada placa de Petri contendo meio de cultura BDA (Potato Dextrose Agar) acrescido dos antibióticos Tetraciclina $\left(50 \mu \mathrm{g} \cdot \mathrm{mL}^{-1}\right)$ e Penicilina $\left(50 \mu \mathrm{g} \cdot \mathrm{mL}^{-1}\right)$, para impedir o crescimento de bactérias. As placas foram incubadas a $28^{\circ} \mathrm{C}$ e avaliadas com 5 dias de crescimento. Com a finalidade de se avaliar a eficácia do processo de desinfecção foi semeada em meio BDA $100 \mu \mathrm{L}$ da água utilizada na última lavagem. As placas foram incubadas a $28^{\circ} \mathrm{C}$ e acompanhadas periodicamente durante o crescimento dos fungos. Colônias fúngicas com características de cada tipo morfológico foram repicadas das placas de isolamento, purificadas e submetidas a extração de DNA para posterior análise.

\subsubsection{Análise dos Dados}

A análise estatística foi feita com o auxílio do programa SAS - Copyright (c) 1989-1996 by SAS Institute Inc., Cary, NC, USA. O delineamento do 
experimento foi inteiramente casualizado. Para a análise dos fungos obtidos, foi calculada a freqüência de isolamento pela razão entre o número de colônias e o número de fragmentos. Os dados foram submetidos a análise de variância (ANOVA) e as médias foram comparadas pelo teste de Duncan.

\subsubsection{Interação de isolados de Fusarium spp. em plantas de tomate e soja}

Isolados endofíticos e patogênicos de Fusarium spp. (Tabela 5) foram utilizados para investigar a interação com plantas tomate e soja.

Tabela 5. Isolados de Fusarium utilizadas no ensaio de interação fungo-planta

\begin{tabular}{ccc}
\hline Isolados & Patogenicidade & Hospedeiro \\
\hline Soja111, Soja130, Soja534, Soja105 & Endofítico & Soja \\
PtTom08 & Patogênico & Soja \\
Cac12, Cac19.4, Cac17.1, Cac65 & Patogênico & Tomate \\
Poty. B. & Endofítico & Cacau \\
PtCan10 & Endofítico & Desconhecido \\
F. verticillioides & Patogênico & Cana \\
F. solani & Patogênico & milho \\
F. solani & Patogênico & Mandioca \\
& Endofítico & Trigo
\end{tabular}

Sementes de tomate (Lycopersicun esculentum Mill, cultivar Kada [tipo Santa Cruz]) e de soja (Glycine max [L.] Merril, cultivar Foscarin), susceptíveis 
ao Fusarium, foram utilizadas no bioensaio, o qual foi conduzido em casa de casa de vegetação, do Campus da Escola Superior de Agricultura "Luiz de Queiroz" - USP, Piracicaba/SP. Para montagem desse ensaio, sementes foram plantadas em tubetes plásticos contendo substrato (Plant Max Hortaliças Eucatex) inoculado com o fungo $\left(10^{8} \mathrm{ufc} \mathrm{g}^{-1}\right.$ de solo) (1 planta por vaso, 15 vasos por tratamento). No controle as sementes foram plantadas em solo sem a adição de inóculo fúngico. A cada 5 dias, uma nova inoculação foi realizada. Este procedimento se repetiu por 3 vezes. Após 15 dias foram avaliadas a capacidade de causar sintomas e a produção de biomassa das plantas avaliadas. A produção de massa seca foi avaliada ao final do experimento por meio da determinação da massa seca do caule e raiz de cada planta em estufa a $70^{\circ} \mathrm{C}$, por 24 horas.

O delineamento experimental foi inteiramente casualizado, com 5 repetições, com relação a produção de massa seca. Os dados foram submetidos a análise de variância (ANOVA) e quando apropriado, as médias foram comparadas pelo teste de Duncan. 


\section{RESULTADOS E DISCUSSÃO}

\subsection{Caracterização morfológica de Fusarium spp.}

Os isolados de Fusarium spp. utilizados neste trabalho apresentaram variabilidade morfológica tanto na coloração da colônia (branca, verde, amarela, rosa e roxa) como na forma dos microconídios e macroconídios (Figura 1).

De modo geral, não foi possível fazer qualquer correlação entre as características fenotípicas observadas com a patogênese, com o hospedeiro, com o nicho e com a taxonomia dos isolados analisados neste presente trabalho. Alguns isolados de F. oxysporum, por exemplo, apresentaram características que eram mais similares a outras espécies de Fusarium do que aos isolados de sua própria espécie. Claramente, uma investigação da variação dentro do gênero Fusarium seria necessária para uma melhor caracterização do gênero. 

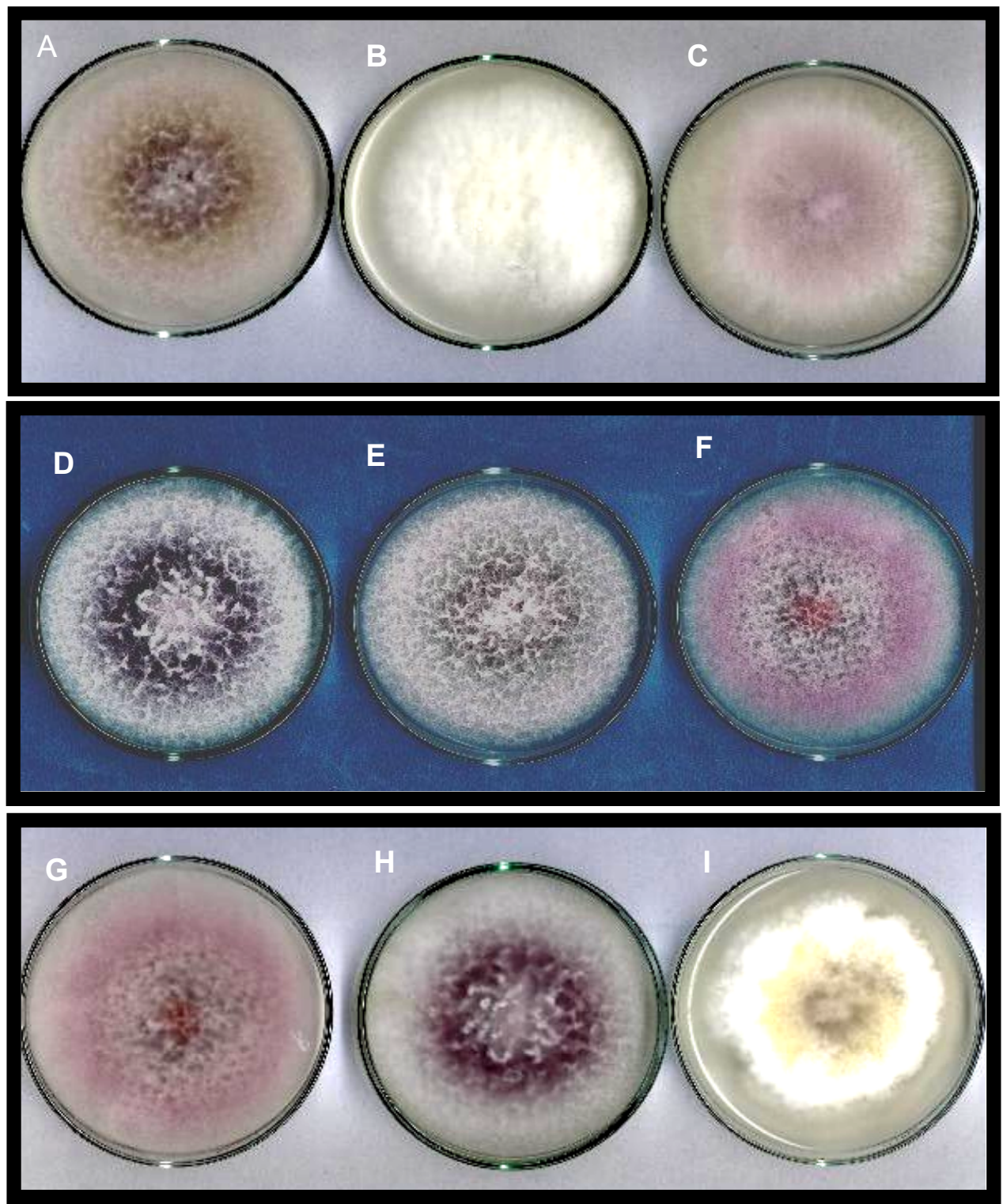

Figura 1 - Aspectos morfológicos de diferentes isolados de Fusarium spp. A) Cac125; B) Cac95; C) Cac19.4; D) PtCan11; E) Soja534; F) Soja111; G) Soja45; H) PtTom8; I) Soja252 


\subsection{Variabilidade genética de Fusarium spp. por meio da análise da região ITS do rDNA}

\subsubsection{Amplificação e restrição do rDNA (ARDRA)}

Os produtos de PCR obtidos na amplificação das regiões ITS1, 5.8S e ITS2 do rDNA dos isolados patogênicos e não patogênicos de Fusarium spp. apresentaram em torno de $600 \mathrm{pb}$, os quais foram clivados com as enzimas de restrição $\mathrm{Mbol}$, Clal e Hhal e fragmentos com tamanho acima de 100 pb foram considerados na presente análise. De acordo com o padrão de clivagem obtido, foi possível observar de 2 a 5 fragmentos por enzima de restrição, sendo obtidos 6 perfis com a enzima Mbol, 7 para a Clal e 9 para a Hhal. A combinação dos padrões de restrição (Figura 2) permitiu a distinção dos 83 isolados de Fusarium spp. em 19 padrões de ARDRA (ou haplótipos) (Tabela $6)$.

A freqüência total dos 19 haplótipos observados pela análise de restrição do rDNA dos isolados patogênicos e não patogênicos de Fusarium, pode ser observada na figura 3. Além disso, foi possível verificar que dentro de um mesmo haplótipo foram agrupados isolados de diferentes hospedeiros, como é o caso dos haplótipos A, C, G, I e R. Também foram observados 10 haplótipos exclusivos (E, $F, H, J, L, N, O, P, Q$, e $S)$, ou seja, contendo um único isolado. Por outro lado, dentro do haplótipo $\mathrm{C}$ foi agrupado um maior número de 
isolados, ou seja, 44 de um total de 83 isolados, sendo estes isolados endofíticos, patogênicos e de solo, obtidos de diferentes hospedeiros.
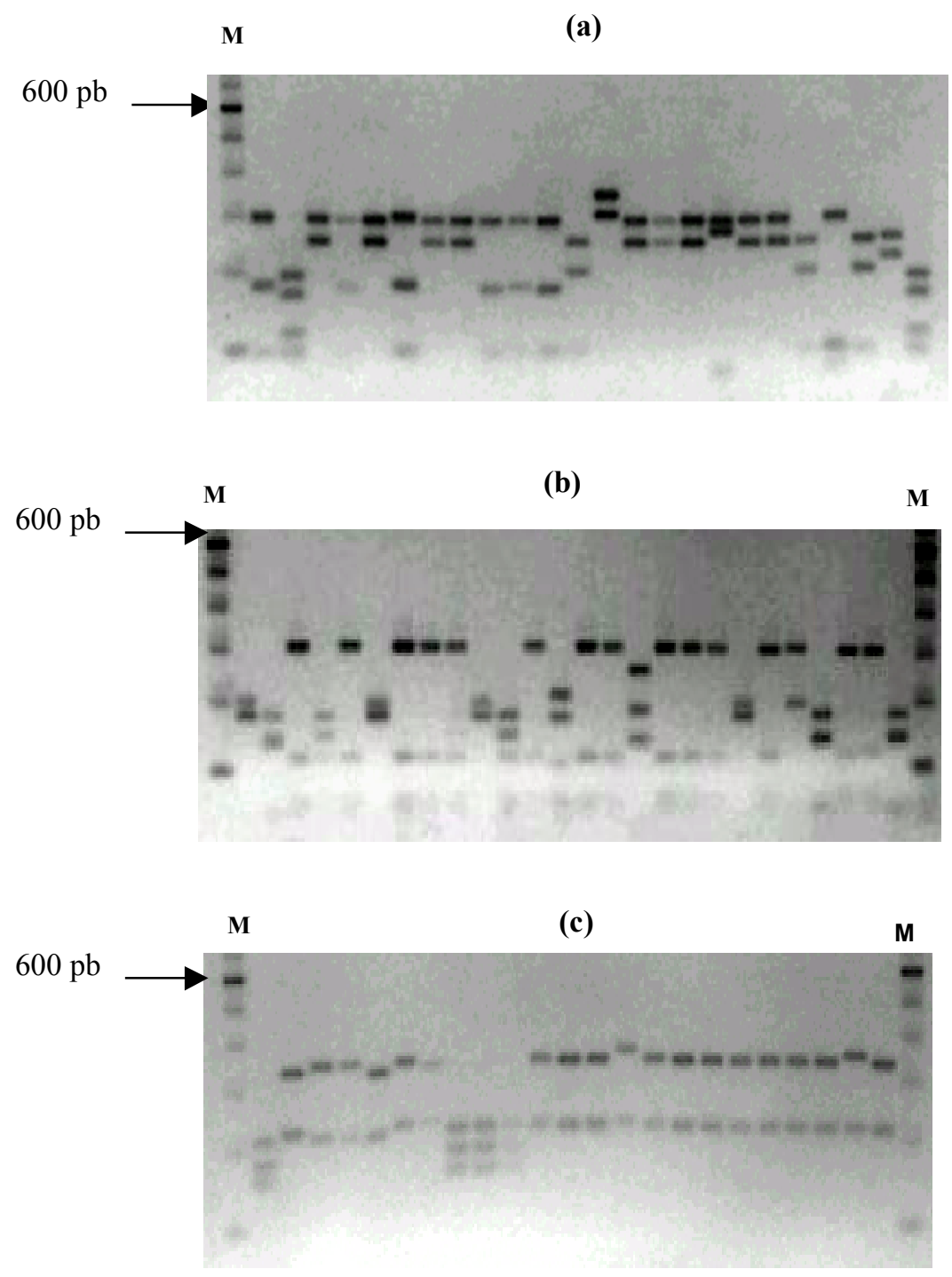

Figura 2 - Perfis de restrição da região ITS do rDNA de alguns isolados de Fusarium spp., utilizando as enzimas: a) Hhal; b) Mbol e c) Clal. M, representa o marcador de peso molecular Ladder 100 pb (Invitrogen) 
Tabela 6. Distribuição dos isolados de Fusarium spp. nos diferentes haplótipos obtidos

\begin{tabular}{lc}
\hline \multicolumn{1}{c}{ ISOLADOS } & HAPLÓTIPOS \\
\hline Cac6.1; Soja252; Cac13.2; Soja102 & $\mathrm{A}$ \\
Cac24.3; Cac19.3; Cac12; Cac27.1; Cac19.4; & $\mathrm{B}$ \\
Soja93; Soja105; Soja267; Soja200; Soja96; Soja111; & $\mathrm{C}$ \\
Soja20; Soja270; Soja41; Soja45; Soja114; Pup06; & \\
Cac19.2; PtSoja539; PtSoja130; PtSoja534; Fran1Solo; & \\
Fran2Solo; Fran3Solo; Fran4Solo; Fran5Solo; & \\
Fran6Solo; Fran7Solo; Fran8Solo; PtMel; PtTom1; & \\
PtTom2; PtTom15; PtTom8; PtLin; Palp; PBot; N1; N2; & \\
Cactus; Lycop; CA4A; C12A; PtGir; PtAlg; F.oxysp; & \\
4014Solo; 4020Solo e Cac77 & \\
Soja69; Soja132; & $\mathrm{D}$ \\
F. brasil & $\mathrm{E}$ \\
Soja116 & $\mathrm{F}$ \\
Soja125; Soja190; Cac64; Cac65; Soja131; Soja73; & $\mathrm{G}$ \\
Soja81 & $\mathrm{H}$ \\
Cac74; Soja20.5; & $\mathrm{I}$ \\
Ca 18 & $\mathrm{J}$ \\
Cac55.1; 4026Solo; & $\mathrm{K}$ \\
Cac 17.1; & $\mathrm{L}$ \\
PtCan3; PtCan4; PtCan5; PtCan6; PtCan9; PtCan11; & $\mathrm{M}$ \\
PtMan & $\mathrm{N}$ \\
Pup80 & $\mathrm{O}$ \\
Cac9522.3 & $\mathrm{P}$ \\
F.solJag; PtMilho & $\mathrm{Q}$ \\
F. gram & $\mathrm{R}$ \\
\hline
\end{tabular}




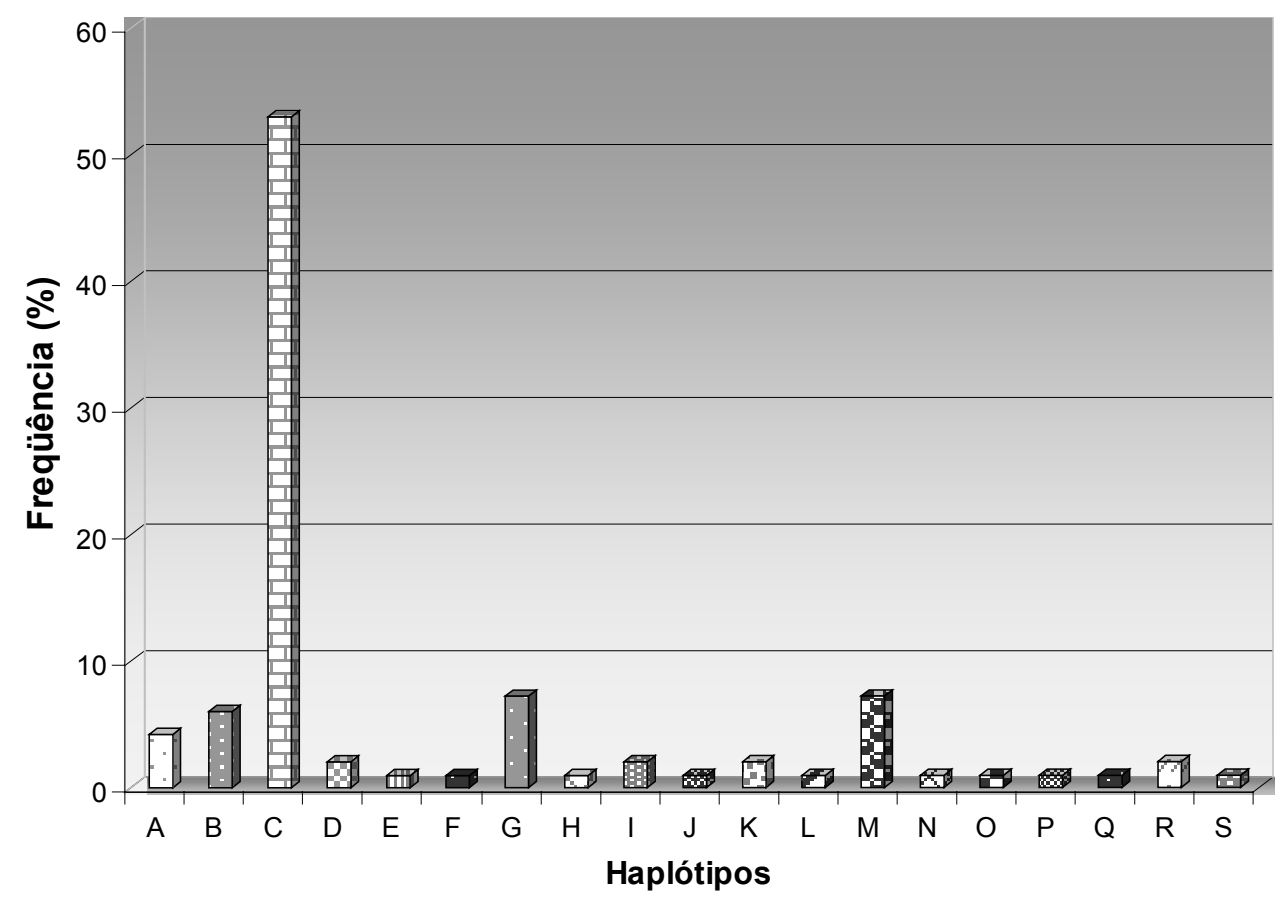

Figura 3 - Freqüência dos 19 haplótipos obtidos pela análise de restrição do fragmento da região ITS do rDNA das isolados de Fusarium spp. com as enzimas Mbol, Clal e Hhal

A análise total dos haplótipos permitiu observar que houve diferença quanto a diversidade dentro de cada haplótipo analisado em relação às diferentes condições avaliadas. Desta forma, de acordo com os resultados obtidos por meio da técnica de ARDRA, os isolados patogênicos e não patogênicos de Fusarium spp. não puderam ser discriminados e não apresentaram correlação nas diferentes condições. Estes resultados poderiam ser explicados por meio da hipótese relatada por Gordon \& Martyn, (1997), onde isolados patogênicos poderiam ter sido originados de uma população não 
patogênica pré-existente ou então que isolados patogênicos perderam a patogenicidade ao longo da evolução da espécie, justificando assim esta estreita relação encontrada entre estes isolados.

Essa não distinção de isolados patogênicos dos não patogênicos de Fusarium spp. poderia também estar relacionada com o questionamento da real condição dos isolados utilizados neste trabalho que foram coletados como endófitos, mas que na realidade poderiam ser patógenos latentes. A infecção latente de plantas por patógenos tem sido reconhecida há muitos anos e é definida como o estágio em que um hospedeiro é infectado com um patógeno mas não apresenta sintomas até que condições favoráveis como nutrientes ou estágio de maturidade da planta hospedeira ou do patógeno faça com que este recupere sua patogenicidade (Agrios, 1988; Viret \& Petrini, 1994). Segundo Freeman \& Rodrigues (1993) dependendo das condições ambientais ou equilíbrio com outros microrganismos, isolados patogênicos podem flutuar entre a colonização endofítica e não apresentar sintomas. Sendo assim, quando microrganismos endofíticos são isolados, pode-se estar isolando também um patógeno latente deste hospedeiro (Azevedo, 1998).

Um outro aspecto a ser discutido em relação aos resultados aqui obtidos, está relacionado ao fato de que a análise por meio da técnica de ARDRA envolve uma única região do genoma, podendo assim não permitir a distinção entre isolados patogênicos e não patogênicos de Fusarium spp., visto que para esta característica podem estar envolvidos inúmeros genes, não avaliados pela técnica de ARDRA. Por outro lado, Oliveira \& Costa (2002) utilizaram a análise 
da região ITS do rDNA, por meio da técnica ARDRA, para relacionar geneticamente isolados de F. solani f.sp. phaseoli e F. solani f.sp. glycines patogênicos ao feijão e/ou à soja. Com base nos resultados obtidos por estas análises, foi possível discriminar estas duas formae speciales. Provavelmente estes autores obtiveram êxito nas suas análises por estarem comparando duas formas patogênicas bem distintas.

Para ampliar o nível de esclarecimentos da identidade, da variabilidade e das relações filogenéticas dos isolados de Fusarium spp, utilizados neste trabalho, os fragmentos amplificados da região ITS do rDNA de isolados representativos de cada um dos haplótipos, foram submetidos ao seqüenciamento. Desta forma aproximadamente $55 \%$ dos isolados foram seqüenciados. Na tabela 7 apresenta a distribuição dos 83 isolados nos diferentes haplótipos, bem como os resultados da identificação obtidos com o seqüenciamento.

Tabela 7. Isolados, hospedeiros, patogênese, procedência, haplótipos e identificação dos isolados de Fusarium spp. utilizados no presente trabalho

\begin{tabular}{ccccccc}
\hline $\mathbf{N}^{\circ}$ & Isolados & Hospedeiro & Patogen. & Procedência & Haplótipo & Identificação \\
\hline 1 & PtCan11 & Cana de açúcar & Patogênico & Copesucar - SP & $\mathrm{M}$ & Gibberella fujikuroi \\
2 & PtCan4 & Cana de açúcar & Patogênico & Copesucar - SP & $\mathrm{M}$ & Gibberella fujikuroi \\
3 & PtCan6 & Cana de açúcar & Patogênico & Copesucar - SP & $\mathrm{M}$ & \\
4 & PtCan3 & Cana de açúcar & Patogênico & Copesucar - SP & $\mathrm{M}$ & \\
5 & PtCan5 & Cana de açúcar & Patogênico & Copesucar - SP & $\mathrm{M}$ & Gibberella fujikuroi \\
\hline
\end{tabular}




\begin{tabular}{|c|c|c|c|c|c|c|}
\hline $\mathbf{N} .^{\circ}$ & Isolados & Hospedeiro & Patogen. & Procedência & Haplótipo & Identificação \\
\hline 6 & PtCan9 & Cana de açúcar & Patogênico & Copesucar - S.P. & M & \\
\hline 7 & PtGir & Girassol & Patogênico & Recife - PE & C & \\
\hline 8 & PtMilho & Milho & Patogênico & Recife - PE & $\mathrm{R}$ & \\
\hline 9 & Soja534 & Soja & Patogênico & Londrina - PR & C & F.o.f.sp.vasinfectum \\
\hline 10 & PtAlg & Algodão & Patogênico & Recife - PE & C & \\
\hline 11 & F.oxys. & Desconhecido & - & Recife - PE & C & F. oxysporum \\
\hline 12 & 4020Solo & Solo & - & IOC - S.P. & C & \\
\hline 13 & Fran6Sol & Solo & N. Patogênico & Dijon - França & C & F.oxysporum \\
\hline 14 & PtL̃in & Linho & Patogênico & Dijon - França & C & F. o.f.sp.lini \\
\hline 15 & Fran7Sol & Solo & N. Patogênico & Dijon - França & C & F. oxysporum \\
\hline 16 & Frañरsol & Solo & N. Patogênico & Dijon - França & C & \\
\hline 17 & Frañ̄sol & Solo & N. Patogênico & Dijon - França & C & \\
\hline 18 & Fran4̇Sol & Solo & N. Patogênico & Dijon - França & C & \\
\hline 19 & PtTóm1 & Tomate & Patogênico & Dijon - França & C & F. o.f.sp.lycopersici \\
\hline 20 & PtMel & Melão & Patogênico & Dijon - França & C & F.o.f.sp.melonis \\
\hline 21 & PtTom2 & Tomate & Patogênico & Dijon - França & C & F. o.f.sp.lycopersici \\
\hline 22 & PtTom15 & Tomate & Patogênico & Dijon - França & C & F. o.f.sp.lycopersici \\
\hline 23 & PtTom8 & Tomate & Patogênico & Dijon - França & C & F. o.f.sp.lycopersici \\
\hline 24 & 4026Solo & Solo & - & IOC - S.P. & K & F.o.f.sp.vasinfectum \\
\hline 25 & Soja130 & Soja & Patogênico & Londrina - PR & C & \\
\hline 26 & Soja539 & Soja & Patogênico & Londrina - PR & C & F.o.f.sp.vasinfectum \\
\hline 27 & Soja20 & Soja & Endofítico & Piracicaba - S.P. & C & F. oxysporum \\
\hline 28 & Soja41 & Soja & Endofítico & Piracicaba - S.P. & C & F.o.f.sp.vasinfectum \\
\hline 29 & Soja45 & Soja & Endofítico & Piracicaba - S.P. & C & F.o.f.sp.melonis \\
\hline 30 & Cac55.1 & Cacau & Endofítico & Itabuna - BA & K & F. oxysporum \\
\hline 31 & Soja200 & Soja & Endofítico & Piracicaba - S.P. & C & \\
\hline 32 & Soja111 & Soja & Endofítico & Piracicaba - S.P. & C & \\
\hline
\end{tabular}




\begin{tabular}{|c|c|c|c|c|c|c|}
\hline N. ${ }^{\circ}$ & Isolados & Hospedeiro & Patogen. & Procedência & Haplótipo & Identificação \\
\hline 33 & Soja114 & Soja & Endofítico & Piracicaba - S.P. & C & \\
\hline 34 & Soja116 & Soja & Endofítico & Piracicaba - S.P. & $\mathrm{F}$ & F.o.f.sp.melonis \\
\hline 35 & Soja267 & Soja & Endofítico & Piracicaba - S.P. & C & \\
\hline 36 & Soja270 & Soja & Endofítico & Piracicaba - S.P. & C & F. oxysporum \\
\hline 37 & Pup06 & Pupunha & Endofítico & Piracicaba - S.P. & C & F.o.f.sp. melonis \\
\hline 38 & Cactus & Cactus & Endofítico & Jaguariúna - S.P. & C & F.o.f.sp. melonis \\
\hline 39 & Palp & Desconhecido & - & Jaguariúna - S.P. & C & \\
\hline 40 & Lycop & Tomate & Patogênico & Jaguariúna - S.P. & C & \\
\hline 41 & PBot & Desconhecido & - & Jaguariúna - S.P. & C & F.o.f.sp. melonis \\
\hline 42 & CA4A & Desconhecido & - & Jaguariúna - S.P. & C & F.o.f.sp. melonis \\
\hline 43 & C21A & Desconhecido & _ & Jaguariúna - S.P. & C & F.o.f.sp. melonis \\
\hline 44 & N1 & Desconhecido & - & Jaguariúna - S.P. & C & F.o.f.sp. melonis \\
\hline 45 & N2 & Desconhecido & - & Jaguariúna - S.P. & C & \\
\hline 46 & Soja93 & Soja & Endofítico & Piracicaba - S.P. & C & \\
\hline 47 & 4014Solo & Solo & - & IOC - S.P. & C & \\
\hline 48 & Cac18 & Cacau & Endofítico & Itabuna - BA & $\mathrm{J}$ & \\
\hline 49 & Cac24.3 & Cacau & Endofítico & Itabuna - BA & B & \\
\hline 50 & Cac19.3 & Cacau & Endofítico & Itabuna - BA & B & Fusarium sp. \\
\hline 51 & Cac74 & Cacau & Endofítico & Itabuna - BA & I & Fusarium sp. \\
\hline 52 & Soja73 & Soja & Endofítico & Piracicaba - S.P. & G & F. denticulatum \\
\hline 53 & Cac64 & Cacau & Endofítico & Itabuna - BA & G & F. equiseti \\
\hline 54 & Cac65 & Cacau & Endofítico & Itabuna - BA & G & \\
\hline 55 & Soja69 & Soja & Endofítico & Piracicaba - S.P. & D & \\
\hline 56 & Cac20.5 & Cacau & Endofítico & Itabuna - BA & I & Fusarium sp. \\
\hline 57 & Cac22.3 & Cacau & Endofítico & Itabuna - BA & Q & F. culmorum \\
\hline 58 & Cac27.1 & Cacau & Endofítico & Itabuna - BA & B & Fusarium sp. \\
\hline 59 & Cac77 & Cacau & Endofítico & Itabuna - BA & c & \\
\hline
\end{tabular}




\begin{tabular}{|c|c|c|c|c|c|c|}
\hline $\mathbf{N} .^{\circ}$ & Isolados & Hospedeiro & Patogen. & Procedência & Haplótipo & Identificação \\
\hline 60 & Cac12 & Cacau & Endofítico & Itabuna - BA & B & Fusarium sp. \\
\hline 61 & Cac17.1 & Cacau & Endofítico & Itabuna - BA & L & Fusarium sp. \\
\hline 62 & Cac6.1 & Cacau & Endofítico & Itabuna - BA & A & Fusarium sp. \\
\hline 63 & Fran5Sol & Solo & N. Patogênico & Dijon - França & C & F. oxysporum \\
\hline 64 & Frañsol & Solo & N. Patogênico & Dijon - França & C & \\
\hline 65 & PtM̂an & Mandioca & Patogênico & Recife - PB & $\mathrm{N}$ & \\
\hline 66 & Fran1Sol & Solo & N. Patogênico & Dijon - França & C & \\
\hline 67 & Cacī19.2 & Cacau & Endofítico & Itabuna - BA & C & F. oxysporum \\
\hline 68 & Cac13.2 & Cacau & Endofítico & Itabuna - BA & A & Nectria \\
\hline 69 & Cac19.4 & Cacau & Endofítico & Itabuna - BA & B & Fusarium sp. \\
\hline 70 & Cac95 & Cacau & Endofítico & Itabuna - BA & $P$ & Nectria \\
\hline 71 & Soja96 & Soja & Endofítico & Piracicaba - S.P. & C & $n \ldots$ \\
\hline 72 & Soja105 & Soja & Endofítico & Piracicaba - S.P. & $\mathrm{C}$ & F. oxysporum \\
\hline 73 & Soja102 & Soja & Endofítico & Piracicaba - S.P. & A & Nectria \\
\hline 74 & Pup80 & Pupunha & Endofítico & Piracicaba - S.P. & $\mathrm{N}$ & F. proliferatrum \\
\hline 75 & Soja81 & Soja & Endofítico & Piracicaba - S.P. & $\mathrm{H}$ & F. dlaminii \\
\hline 76 & F.brasil & Soja & Patogênico & Piracicaba - S.P. & $E$ & F. brasiliensis \\
\hline 77 & Soja125 & Soja & Endofítico & Piracicaba - S.P. & D & \\
\hline 78 & Soja132 & Soja & Endofítico & Piracicaba - S.P. & $\mathrm{D}$ & F. dlaminii \\
\hline 79 & FsolJag & Trigo & Patogênico & Jaguariúna - S.P. & $\mathrm{R}$ & \\
\hline 80 & Soja131 & Soja & Endofítico & Piracicaba - S.P. & G & \\
\hline 81 & Soja190 & Soja & Endofítico & Piracicaba - S.P. & $\mathrm{G}$ & F. chlamydosporum \\
\hline 82 & Soja252 & Soja & Endofítico & Piracicaba - S.P. & $A$ & \\
\hline 83 & Fgram & Trigo & Patogênico & Jaguariúna - S.P. & S & \\
\hline
\end{tabular}

A maioria dos isolados identificados como $F$. oxysporum $(93,6 \%)$ foram agrupados no haplótipo $\mathrm{C}$, sendo que o restante $(6,3 \%)$ destes isolados 
agrupou nos haplótipos K e F. Por outro lado o haplótipo G agrupou isolados de diferentes espécies de Fusarium, como F. chlamydosporum, F. denticulatum e F. equiseti. Dessa forma, de acordo com os resultados obtidos, foi verificada uma grande diversidade genética entre os isolados nos diferentes hospedeiros, não sendo observada especificidade quanto a colonização em relação ao hospedeiro, como por exemplo o F. oxysporum f. sp. melonis, foi encontrado em pupunha, soja, melão e cactus. Baseado nestes fatos pode-se sugerir que existem muitos erros classificação atual do Fusarium, a qual parece não resultar de uma proximidade filogenética.

Um dos grandes impedimentos no estudo de Fusarium tem sido a aplicação incorreta e confusa de nomes de espécies, devido em grande parte às limitações do reconhecimento morfológico das espécies e suas aplicações Esta situação tem levado a uma grande confusão fazendo com que variantes de uma mesma espécie seja identificada como sendo de outra espécie.

Em relação às sequências obtidas, estas foram alinhadas e analisadas pelo BLASTn e programa PAUP, permitindo que árvores filogenéticas fossem construídas (Figura 4). 
(A)

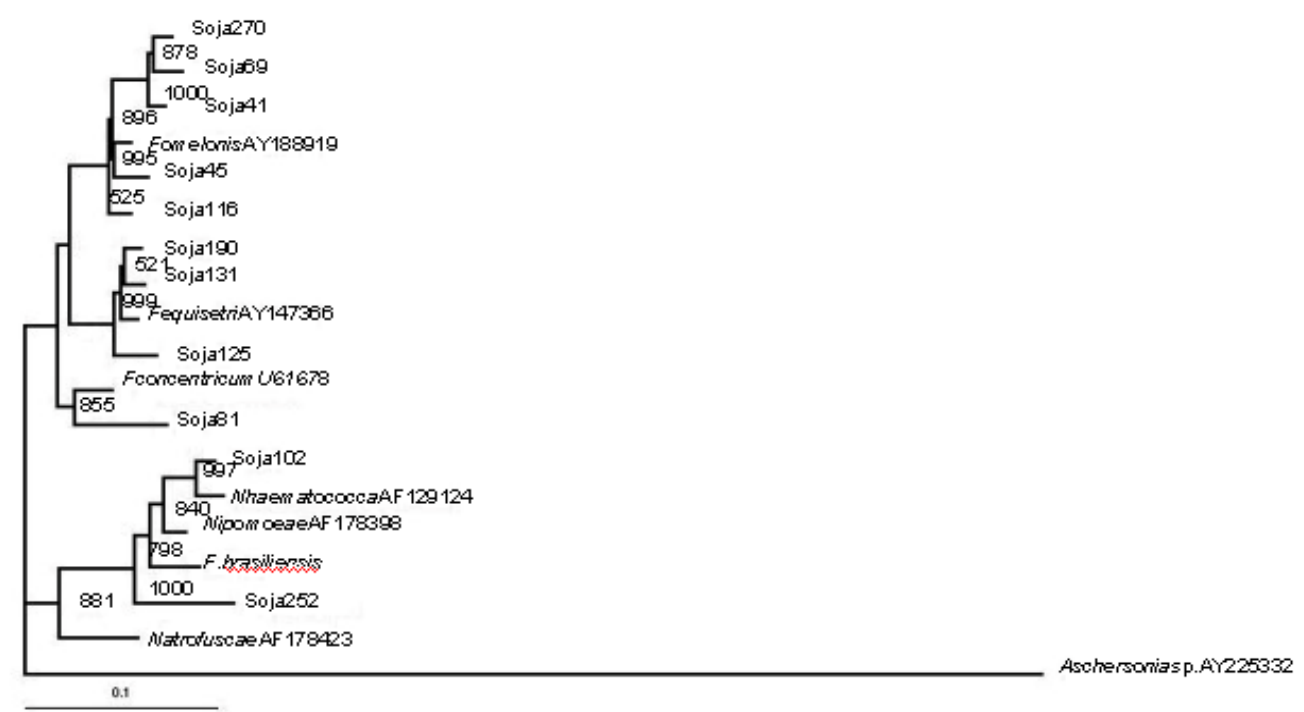

(B)

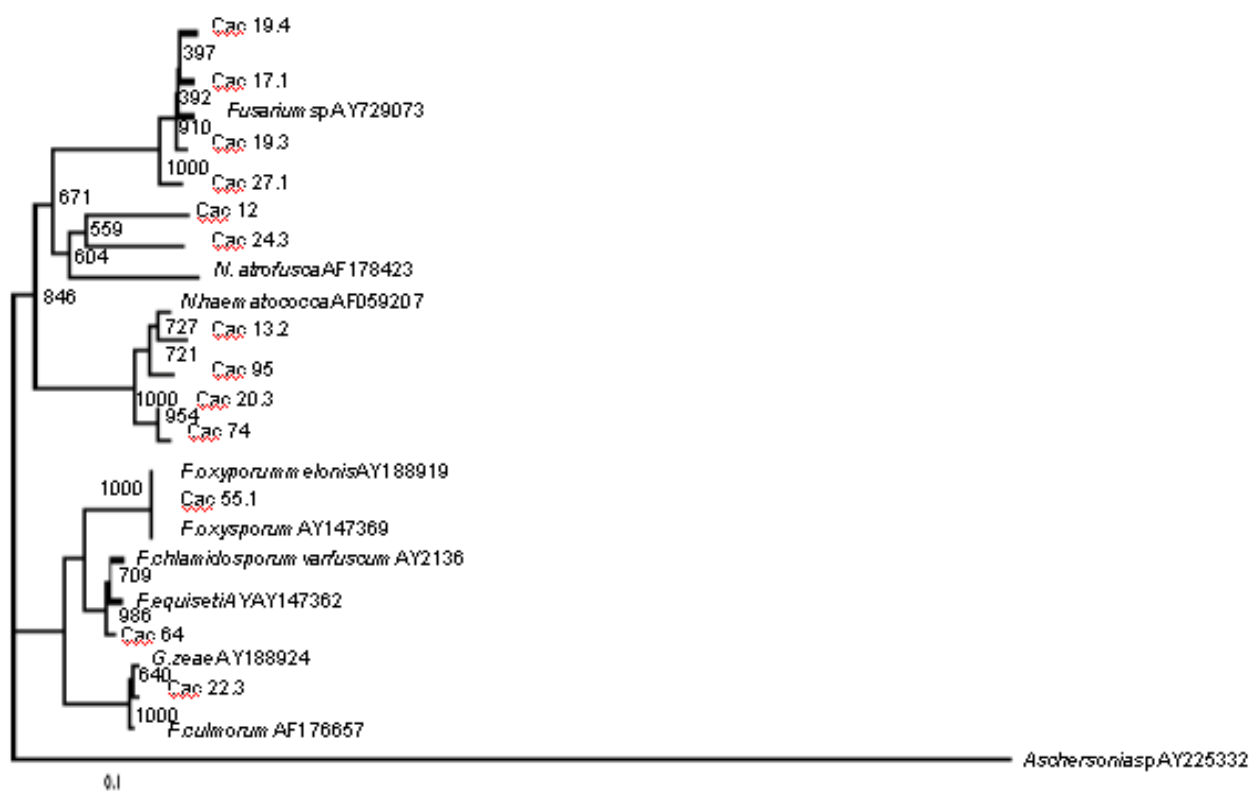

Figura 4 - Árvores filogenéticas construídas pelo programa PAUP a partir de seqüências da região ITS do rDNA. (A) Isolados de Soja e (B) Isolados de Cacau. O isolado Aschersonia sp. foi utilizado como outgroup 
Comparações genéticas entre populações fúngicas patogênicas e não patogênicas, baseadas na análise das seqüências do rDNA, podem ser ferramentas úteis para investigar e determinar a condição de patogenicidade do fungo em estudo (Kuninaga et al., 1997, Oliveira \&Costa, 2002; Lana, 2004). Os resultados obtidos mostraram que alguns isolados endofíticos tanto de soja como de cacau foram agrupados com isolados patogênicos, como por exemplo os isolados Soja270, Soja69, Soja45, Soja41 e Soja116 que se ligaram à um isolado patogênico de $F$. oxysporum f.sp. melonis. Ainda nesta mesma árvore filogenética, um outro grupo foi formado onde isolados endofíticos de soja, Soja102 e Soja20 foram agrupados com o isolado patogênico de soja utilizado neste trabalho, o F. brasiliensis. Dessa mesma forma, os isolados Cac13.2, Cac95, Cac20.3 e Cac74 agruparam-se com um isolado de Nectria haematococca que é a forma teleomórfica de $F$. solani, o qual é patogênico para vários hospedeiros, como batata, feijão, soja.

Por outro lado os isolados Cac19.4, Cac17.1, Cac19.3 e Cac27.1 não apresentaram similaridade com isolados patogênicos e desse modo pode-se sugerir que são isolados endofíticos. Estudos como estes são de fundamental importância quando se tem como objetivos a seleção de isolados endofíticos para serem utilizadas tanto no biocontrole como para estudos que envolvam processos biotecnológicos. 


\subsection{Análise da variabilidade genética de Fusarium spp. por RAPD}

\subsubsection{Otimização da técnica de RAPD e seleção de oligonucleotídeos}

Isolados patogênicos e não patogênicos de Fusarium spp. obtidos de diferentes hospedeiros foram analisados quanto a variabilidade genética por meio da técnica de RAPD. Os isolados utilizados neste trabalho estão descritos na Tabela 7. Inicialmente foram feitas extrações dos DNAs destes isolados, que foram submetidos a análise eletroforética em gel de agarose $0,8 \%$, para verificar a integridade e concentração do DNA genômico. Segundo Williams et al. (1993), as principais variáveis a serem ensaiadas, são concentrações altas de DNA e magnésio que podem ocasionar perda de bandas, enquanto que concentrações baixas originam bandas não reproduzíveis. Assim, inicialmente procedeu-se a otimização da técnica de RAPD para os isolados de Fusarium spp. por meio da determinação da melhor concentração de $\mathrm{Mg}^{++}$na reação de amplificação, sendo que os perfis mantiveram inalterados nas concentrações de 3,0, 4,0 e 5,0mM, sendo por isso utilizado $3,0 \mathrm{mM}$ de $\mathrm{Mg}^{++}$por reação.

O efeito da concentração de DNA genômico na reação, dentro do espectro de 5 a 100 $\eta$ foi também avaliado. O melhor resultado obtido ficou em

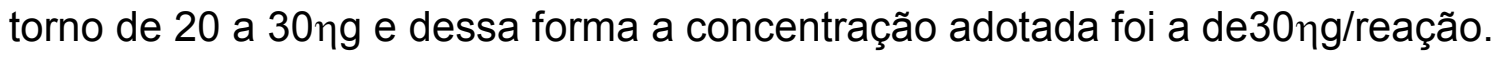
A reação de amplificação foi feita para um volume final de $25 \mu \mathrm{L}$ onde a concentração e os componentes utilizados na reação estão listados na Tabela 3. 


\subsubsection{Polimorfismo por RAPD}

Os isolados patogênicos e não patogênicos (Tabela 7) de Fusarium spp. obtidos de diferentes hospedeiros, foram utilizados nos estudos de variabilidade genética, por meio de marcadores moleculares RAPD. A análise de polimorfismos dos isolados foi realizada utilizando 14 oligonucleotídeos de seqüência arbitrária. Cada primer analisado gerou um padrão de bandas bem distinto que proporcionou a observação de um total de 166 bandas. Dentre estas, $6,1 \%$ das bandas foram monomórficas, conseqüentemente 93,9 das outras bandas foram polimórficas. Os amplicons obtidos com os 14 primers analisados geraram fragmentos que variaram de 3,5 a 0,3 kb (Figura 5).

A análise do padrão de bandas gerado por cada primer utilizado permitiu a construção de uma matriz de similaridade segundo o coeficiente de Jaccard. O método de UPGMA construiu um dendrograma (Figura 6), onde foram observados diferentes níveis de similaridade (100 \% a 10,2\%).

De acordo com o dendrograma obtido foi possível verificar a formação de dois grupos, um menor agrupando alguns isolados endofíticos de cacau e um outro maior englobando o restante dos isolados. A similaridade entre estes dois grupos foi de $16 \%$, ou seja, a variabilidade entre eles é grande. O grupo maior foi subdividido em 3 outros grupos com diferentes níveis de similaridade, mas de forma geral, a variabilidade genética dentro dos mesmos foi alta. Foi observada a formação de pequenos grupos isolados tanto em relação a patogênese como ao hospedeiro. Os isolados patogênicos de cana de açúcar 
(PtCan), por exemplo, ficaram todos em um único grupo. Por outro lado, parte dos isolados de soja formaram pequenos grupos dispersos pelo dendrograma e em alguns casos, dentro desses agrupamentos, foi possível discriminar isolados endofíticos e patogênicos. A outra parte dos isolados de soja apresentou-se dispersa pelo dendrograma misturando-se entre os demais isolados endofíticos e patogênicos de diferentes hospedeiros. Da mesma forma, os isolados endofíticos de cacau ficaram dispersos por todo o dendrograma. Os isolados patogênicos e não patogênicos provenientes da França (PtTom, PtLinh, PtMel e FranSolo) formaram um grupo coeso no dendrograma. Mas de forma geral, com base nos dados obtidos por meio da técnica de RAPD, foi observada uma grande variabilidade genética entre os isolados de Fusarium spp, tanto obtidos de um mesmo hospedeiro como entre isolados de hospedeiros diferentes. Dessa forma não foi possível fazer qualquer associação em relação a especificidade ao hospedeiro, patogênese e padrão de RAPD, conseqüentemente não foi possível distinguir geneticamente isolados patogênicos e não patogênicos. Esses resultados coincidem com os obtidos utilizando a técnica de ARDRA.

De fato, se a diferença entre isolados patogênicos e não patogênicos estiver associada a poucos genes, ou a genes relacionados à fisiologia, que podem alterar a forma de interação entre a planta hospedeira, dificilmente, por meio de análises utilizando marcadores moleculares aleatórios, permitirá a distinção entre estes isolados. Resultado semelhante foi observado por Lana (2004) quando comparou a variabilidade genética de isolados endofíticos e 
patogênicos de Crinipellis perniciosa por meio das técnicas de RAPD e ARDRA. Por outro lado, Glienke-Blanco (1999) analisando a variabilidade genética de populações endofíticas e patogênicas de Guignardia citricarpa por meio da técnica de RAPD, conseguiu diferenciar as duas populações, selecionando uma banda exclusiva encontrada somente em isolados patogênicos. Esta banda foi clonada, seqüenciada e primers específicos foram construídos para diferenciar os isolados patogênicos dos não patogênicos, comprovando os resultados de McOnei (1964) que observou infecções sintomáticas e assintomáticas em G. citricarpa. 

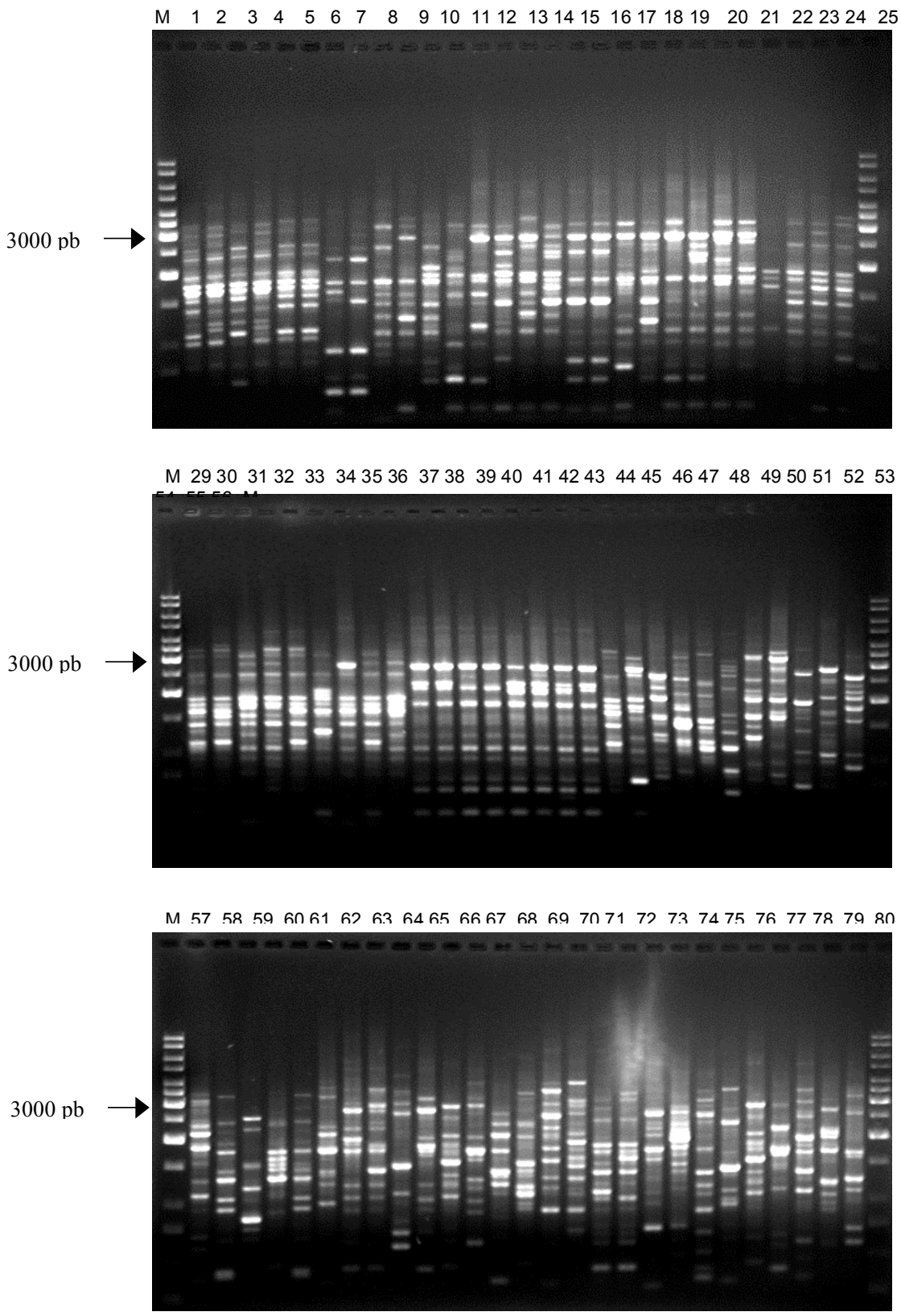

Figura 5 - Perfil de RAPD de isolados de patogênicos e não patogênicos de Fusarium spp. amplificadas com o primer OPC 06. Os números nas canaletas representam os isolados de Fusarium na mesma ordem que aparecem na Tabela 7. M representa o marcador de peso molecular Ladder $1 \mathrm{~kb}$ (Fermentas) 


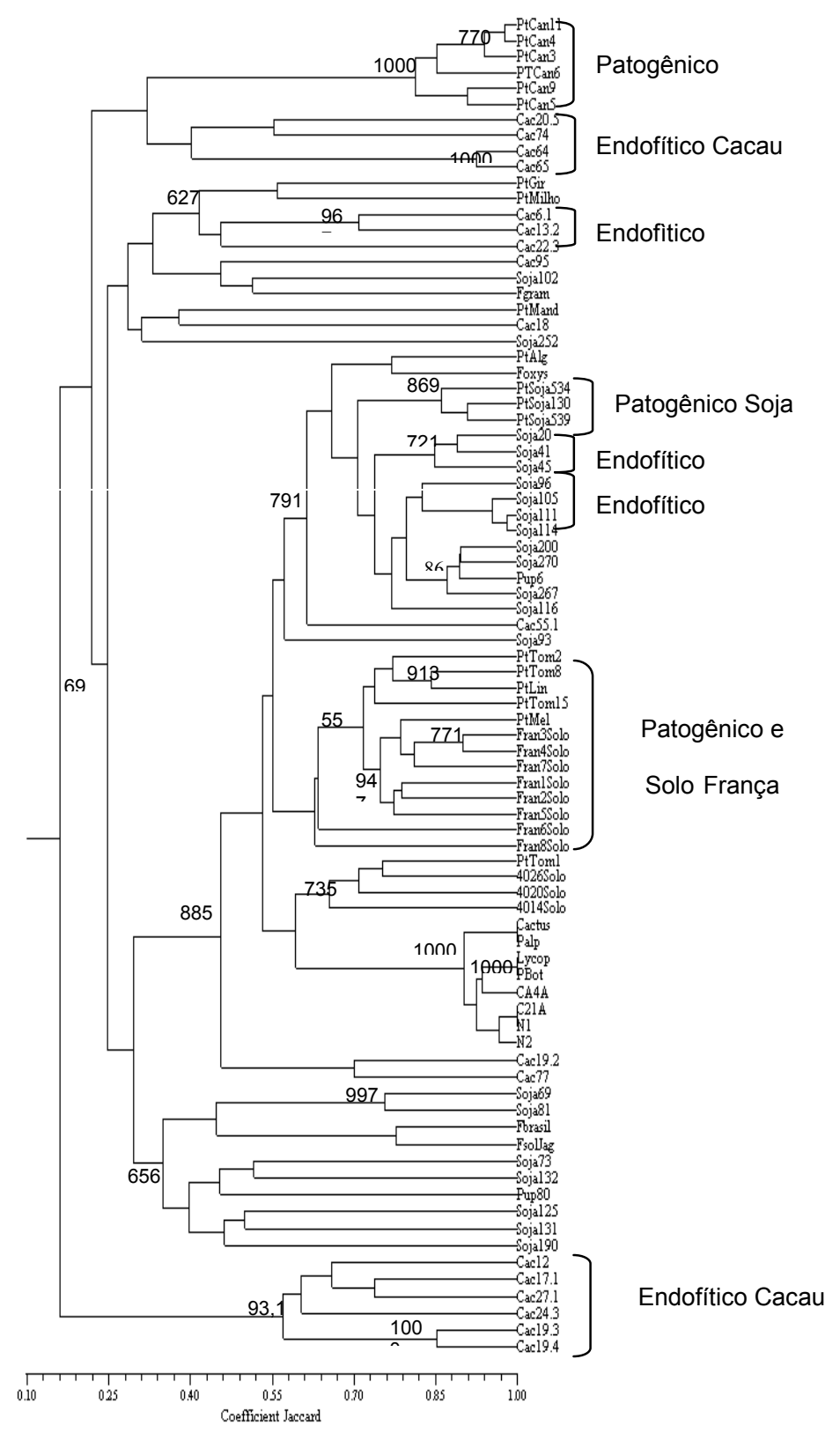

Figura 6 - Dendrograma construído pelo método de agrupamento UPGMA, a partir do coeficiente de Jaccard. Os códigos a direita representam os isolados de Fusarium spp. e os números no dendrograma indicam a porcentagem de vezes que o grupo da direita ocorreu no mesmo nó durante a avaliação do consenso (bootstrap) 
Por outro lado, foi observado que os isolados endofíticos de cacau (Cac19.3, Cac19.4, Cac17.1, Cac24.3, Cac27.1 e Cac12) não se agruparam com formas patogênicas conforme mostram os resultados obtidos por meio das técnicas moleculares utilizadas (ARDRA, RAPD e seqüenciamento de rDNA). Dessa forma, esses isolados endofíticos de cacau poderão ser selecionados para futuros estudos, os quais poderão auxiliar em uma melhor utilização prática destes microrganismos maximizando a consistência e eficácia não só para o biocontrole, mas também na exploração do seu potencial biotecnológico.

\subsubsection{Análise da diversidade de isolados de Fusarium utilizando o índice de Shannon}

O estudo da diversidade genética de comunidades microbianas associadas às plantas pode ser enriquecida com o conhecimento da estrutura e diversidade genética das populações fúngicas (patogênicas, endofíticas e de solo) avaliadas. Contudo, o estudo da estrutura genética de comunidades fúngicas associadas às plantas é importante para o entendimento de como estas comunidades interagem com entre si e com a planta hospedeira.

Dessa forma, a diversidade genética de isolados patogênicos e não patogênicos (endofíticos e de solo) foi comparada entre si, por meio do índice de diversidade de Shannon utilizando os dados gerados pela técnica de RAPD. Foi verificado que a diversidade existente entre os isolados patogênicos não apresentou diferenças significativas em relação a diversidade dos isolados 
endofíticos. Entretanto, houve diferença em relação a diversidade encontrada nos isolados de solo sendo esta significativamente menor, quando comparada com as demais populações aqui analisadas (Tabela 8 e Figura 7).

Tabela 8. Quadro de análise da diversidade das isolados de Fusarium endofíticas, patogênicas e de solo

\begin{tabular}{lccccc}
\hline Isolados & $\begin{array}{c}\text { Diversidade } \\
\text { (Shannon) }\end{array}$ & Variância & Interação & Teste t & GL \\
\hline Endofíticos & $4,6477 \mathrm{~A}$ & 0,000261273 & Endo x Pat & 1,5858 & 2476,0433 \\
Patogênicos & $4,5662 \mathrm{~A}$ & 0,00040393 & Endo x Solo & 10,8062 & $1292,5624^{*}$ \\
Solo & $4,2734 \mathrm{~B}$ & 0,000472948 & Solo x Pat & 11,2694 & $1460,7971^{*}$ \\
\hline * valores diferem estatisticamente a 0,05\% & & &
\end{tabular}

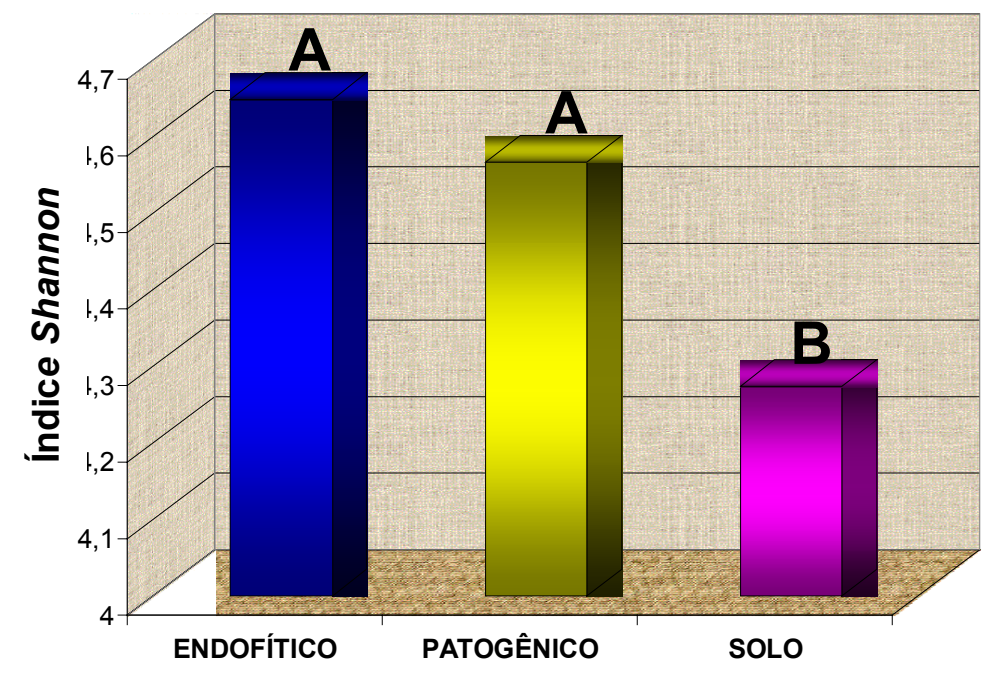

Figura 7 - Diversidade genética de isolados de Fusarium spp. endofíticos, patogênicos e de solo calculado por meio do índice de Shannon. As barras no gráfico com letras iguais não diferem estatisticamente ( $p$ $<0,05 \%)$ 
Analisando os resultados obtidos por esta análise pode ser notado que os isolados de solo apresentaram diversidade menor quando comparada com os isolados endofíticos e patogênicos. Segundo Gordon \& Martyn, (1997), uma das hipóteses para explicar a baixa variabilidade de isolados no solo é o fato de que estes isolados podem ser encontrados aderidos as raízes mas não atingem o córtex da planta hospedeira. Alternativamente isolados patogênicos e endofíticos conseguem penetrar na planta hospedeira, podendo atingir os vasos xilemáticos, adaptando-se por sua vez às mudanças do genótipo do hospedeiro, para aumentar as situações de íntima coevolução. Essa coevolução, particularmente devido à pressão de seleção exercida pela planta, faz com que ocorram mudanças genéticas que podem ser mutações simples ou mediada por elementos transponíveis. Essas mutações podem gerar variabilidade e no caso de isolados patogênicos, resultando em novas raças.

\subsubsection{Análise da variabilidade genética de $F$. oxysporum}

Com base nos resultados obtidos por meio da técnica de ARDRA, foi verificado que a maior parte dos isolados avaliados estão no haplótipo $\mathrm{C}$, os quais foram identificados por seqüenciamento como sendo da espécie $F$. oxysporum. Dessa forma, foi realizada uma análise mais detalhada destes isolados por meio da técnica de RAPD, utilizando 7 primers (OPAX 10, OPAX 12, OPC 06, OPP 16, OPP 12, OPW 08, OPX 11). A Figura 8 ilustra o perfil de amplificação dos 44 isolados de $F$. oxysporum com o primer OPAX 10. Cada 
primer analisado gerou um padrão de bandas bem distinto que proporcionou a observação de um total de 92 bandas, sendo $18 \%$ bandas monomórficas.

A análise do padrão de bandas gerado por cada primer utilizado, permitiu a construção de uma matriz de similaridade segundo o coeficiente Jaccard. O método de UPGMA gerou um dendrograma que encontra-se na Figura 9, onde foram observados diferentes níveis de similaridade (variando de $100 \%$ a $38 \%)$. 

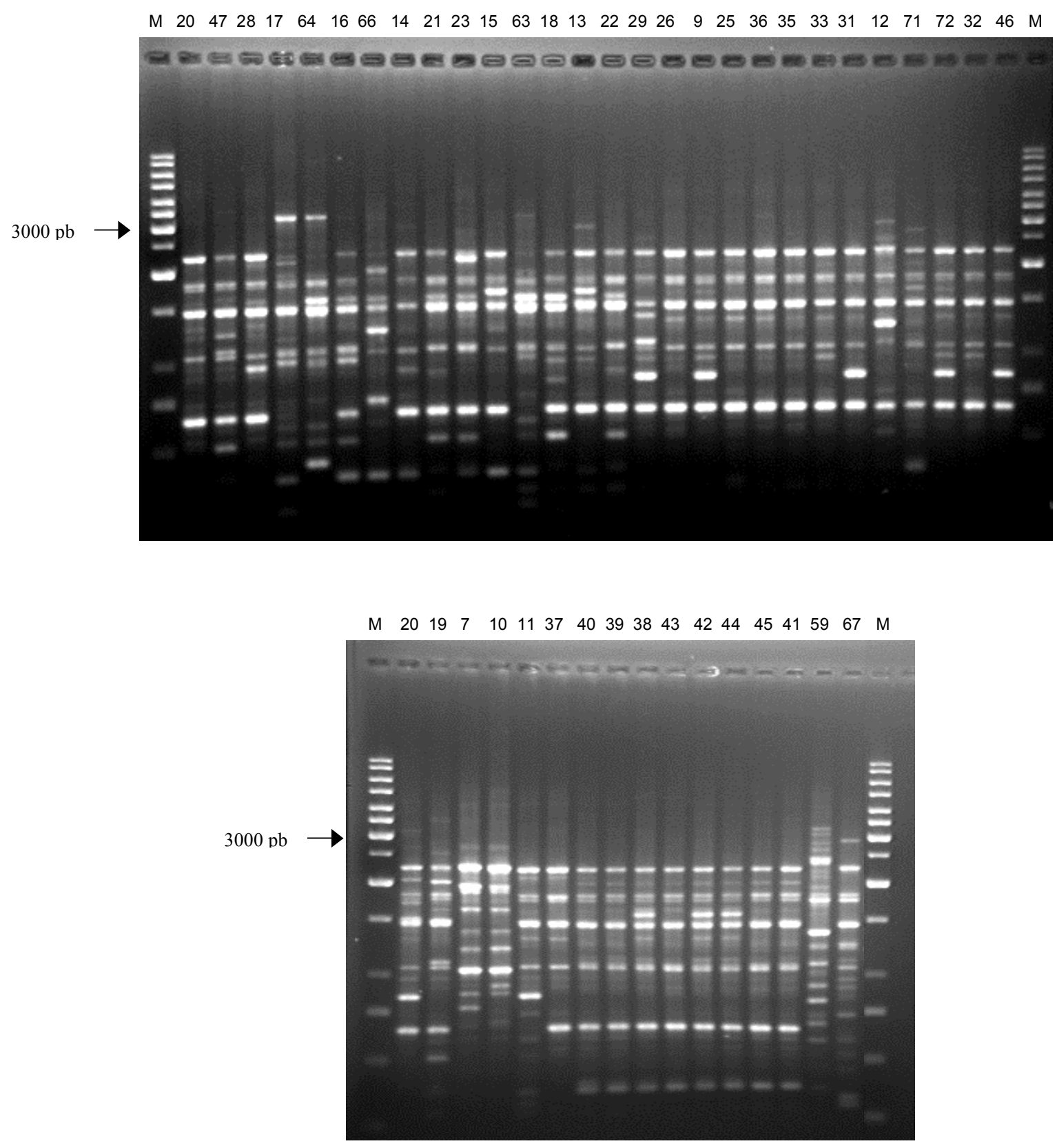

Figura 8 - Perfil de RAPD dos isolados de F. oxysporum agrupados no haplótipo C obtido com o primer OPAX 10. Os números nas canaletas representam os isolados de $F$. oxysporum na mesma ordem que aparecem na Tabela 7. M representa o marcador de peso molecular Ladder $1 \mathrm{~kb}$ (Fermentas) 


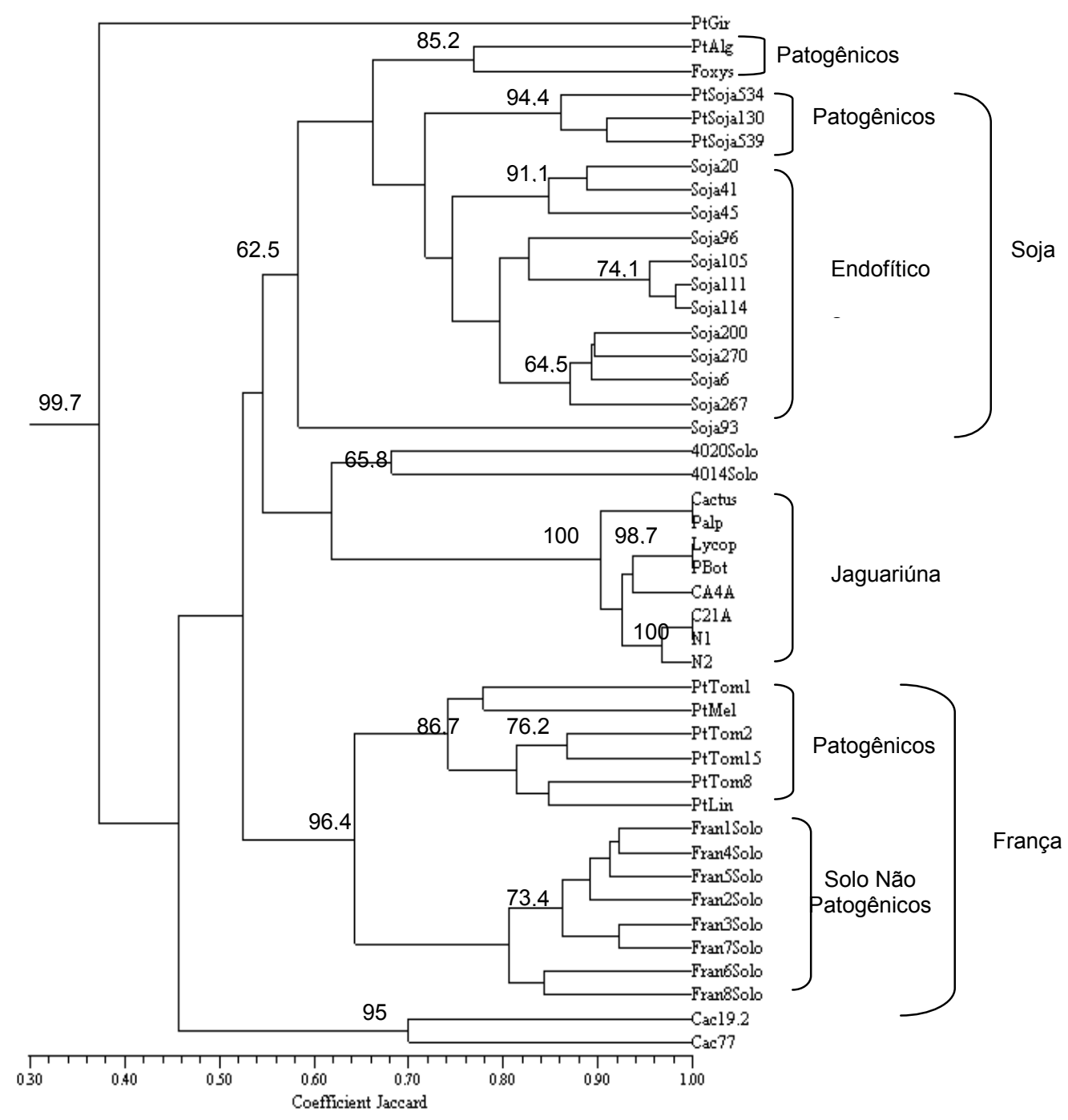

Figura 9 - Dendrograma construído pelo método de agrupamento UPGMA, a partir dos coeficientes Jaccard. Os códigos a direita representam os isolados de Fusarium spp. e os números no dendrograma indicam a porcentagem de vezes que o grupo da direita ocorreu no mesmo nó durante a avaliação do consenso (bootstrap) 
De acordo com o dendrograma obtido, foi possível observar a formação de grupos mais homogêneos e discretos como por exemplo, os isolados de soja, formaram um grupo e dentro deste grupo foi possível distinguir isolados patogênicos dos endofíticos. Da mesma forma ocorreu com os isolados provenientes da França, discriminando os isolados patogênicos dos isolados de solo. Neste contexto, a utilização da técnica de ARDRA neste trabalho, auxiliou na obtenção de um agrupamento preliminar dos isolados de Fusarium spp, o qual possibilitou uma análise posterior por meio do RAPD. Desta forma, a utilização em conjunto destas duas técnicas permitiu a distinção de isolados patogênicos e não patogênicos de $F$. oxysporum de soja.

A variabilidade genética de Fusarium tem sido estudada. Entretanto, a maioria dos estudos está relacionada com variabilidade de formas patogênicas deste gênero (Assigbetse et al., 1994; Mês et al., 1999; Vakalounakis \& Fragkiadakis, 1999; Jiménez-Gasco et al., 2001, Pasquali et al., 2003; Belabid et al., 2004). Gherbawy (1999) utilizou marcadores RAPD para analisar a diversidade genética de 20 isolados de 14 formae speciales de $F$. oxysporum. Os isolados foram alocados em três grupos, que não apresentaram nenhuma correlação com a origem geográfica.

Sivaramakrishnan et al. (2002) também avaliaram a variabilidade de 43 isolados de F. oxysporum f. sp. ciceri, coletados de nove estados da Índia. Análise de similaridade desses isolados patogênicos, gerada pelos marcadores de RAPD resultou em três diferentes grupos sendo que dois destes representaram a raça 1 e 2 e o terceiro foi formado pelas raças 3 e 4 . Os 
marcadores moleculares mostraram que as raças 1 e 2 apresentam grande diversidade quando comparada com as raças 3 e 4 . Foi detectado um grande nível de variabilidade genética entre e dentro das raças de $F$. oxysporum f.sp. ciceri. Os autores consideram que as similaridades e diferenças nos padrões de bandas obtidos por RAPD poderiam ser uma ferramenta molecular útil em estudos evolutivos quanto a origens de diferentes raças.

\subsection{Interação fungo-planta}

\subsubsection{Reisolamento de Fusarium spp. em plantas de tomate}

Foi realizado um isolamento para avaliar se os isolados envolvidos no experimento de controle biológico (item 3.11.1) realmente haviam colonizado a planta hospedeira. Por meio da metodologia de isolamento por fragmentação descrita no item 3.11.1.1 para fungos endofíticos, foi possível isolar fungos de raiz e caule (Figura 10), obtendo uma freqüência de isolamento (FI) de aproximadamente $39 \%$ e $15 \%$ respectivamente. Como pode ser observado, a freqüência obtida na raiz foi maior do que a freqüência encontrada no caule (Figura 11). 


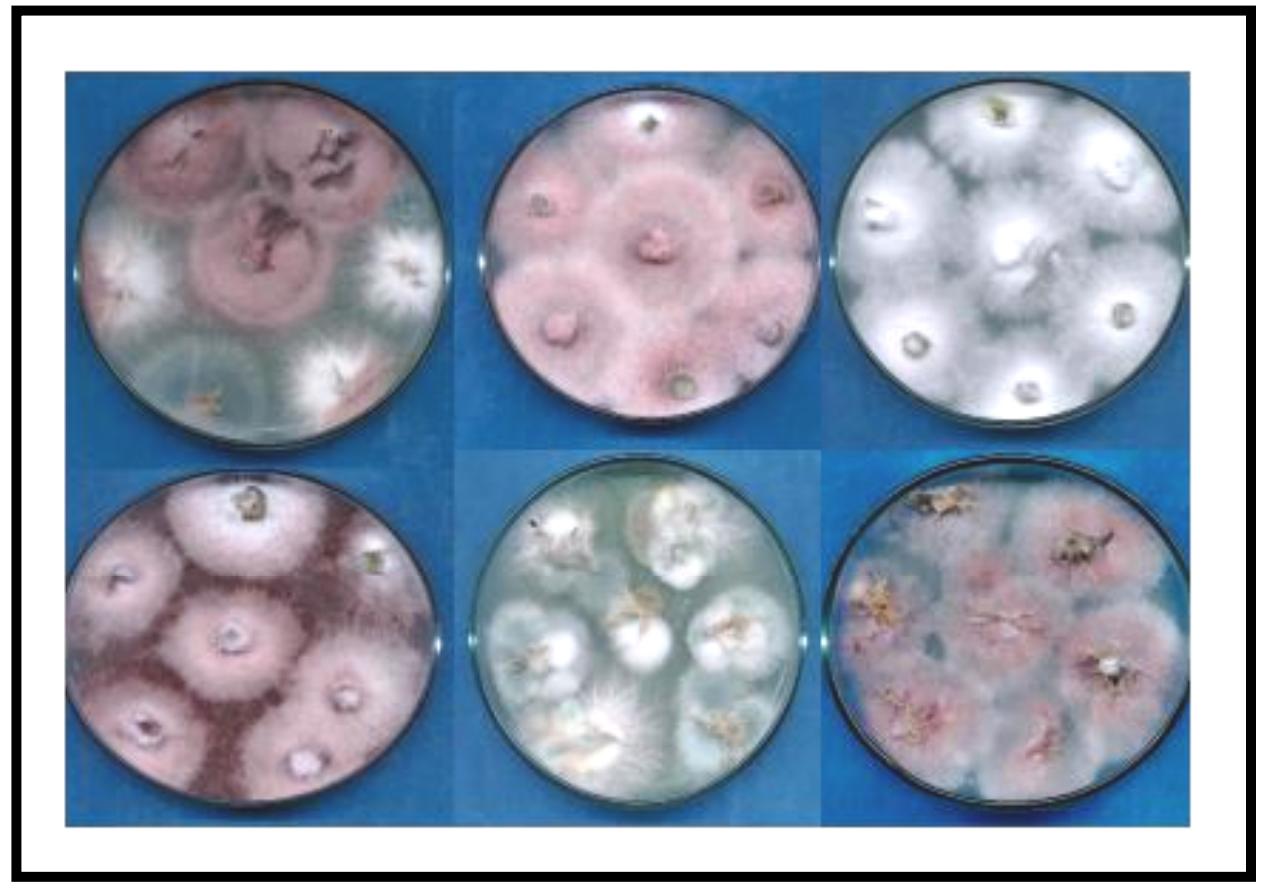

Figura 10 - Isolamento de fungos endofíticos e patogênicos de Fusarium spp. por meio da técnica de fragmentos

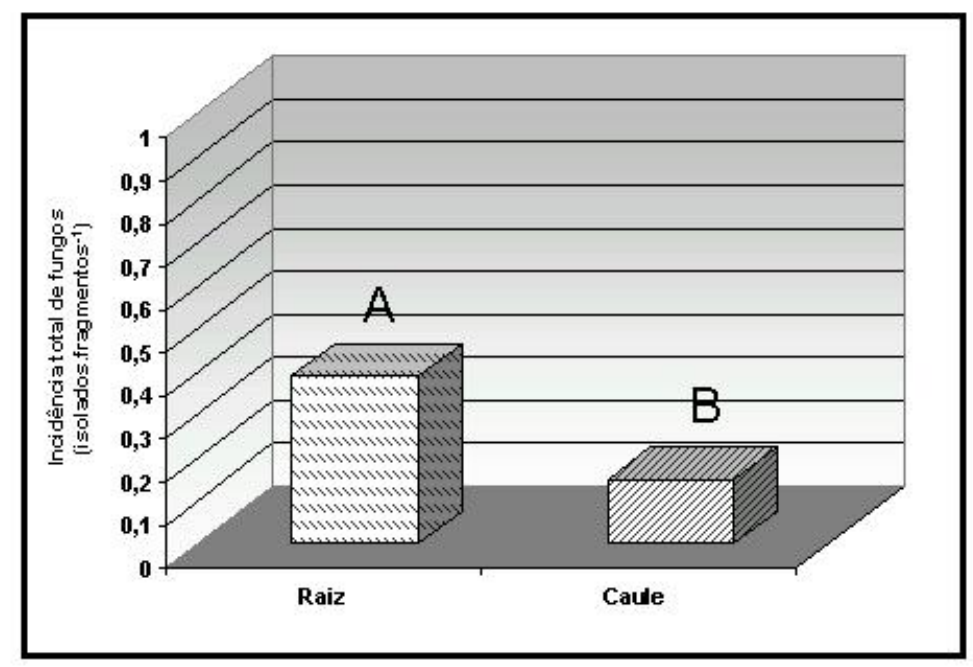

Figura 11 - Freqüência total do isolamento de fungos de caule e raiz de tomate 
Um outro aspecto importante neste experimento, foi avaliar o quanto a presença dos fungos inoculados (endofíticos, patogênico e interação endófito/patógeno) interferem no crescimento de outras espécies fúngicas tanto, no caule como na raiz. (Figura 12). Com base nos resultados obtidos, foi verificado que houve diferença significativa $(p>0,05)$ em relação aos diferentes tratamentos tanto no caule como na raiz. Uma maior freqüência de outros isolados fúngicos colonizando a raiz foi observada, quando comparada com a freqüência de isolados em caule. Foi possível observar que os isolados, Cac12, Cac95, P Bot. e Soja69 de Fusarium, apresentaram um modo de ação semelhante tanto no caule como na raiz, ou seja permitindo a colonização de outras espécies fúngicas quando inoculados sozinhos. Por outro lado, quando inoculados com o patógeno PtTom8, foi verificado uma diminuição na colonização de outras espécies fúngicas. O mesmo não foi observado com o isolado Cac19.4, que não apresentou diferenças no modo de ação no caule e na raiz, bem como quando inoculado sozinho ou juntamente com o patógeno. Em relação ao controle, todos os tratamentos com os isolados inoculados, tanto sozinhos ou juntamente com o patógeno, em caule e raiz, apresentaram uma inibição na colonização de outras espécies fúngicas. Com base nos resultados pode-se observar que a colonização e distribuição destes fungos nos diferentes tecidos da planta hospedeira são influenciadas por interações entre estes microrganismos bem como o seu próprio tipo de interação com a planta hospedeira. 
A forma de colonização, penetração e competição entre diferentes microrganismos têm sido abordada na literatura (Hervas et al., 1997; Larkin \& Fravel, 1999; Olivain \& Alabouvette, 1999). Postma \& Luttikhoet, (1996) consideraram a hipótese de competição direta entre duas linhagens de $F$. oxysporum em vasos de planta. Eles compararam a colonização de uma linhagem não patogênica inoculada artificialmente em raízes da planta hospedeira. Esta comparação foi realizada inoculando a linhagem não patogênica sozinha ou em combinação com uma outra linhagem patogênica em vasos de planta. Eles verificaram que a linhagem não patogênica foi capaz de reduzir a colonização da linhagem patogênica no caule resultando em um decréscimo da severidade da doença. Estes resultados demonstram a existência de competição entre estas linhagens não somente no sítio de infecção na raiz mas também em outros tecidos da planta hospedeira. 


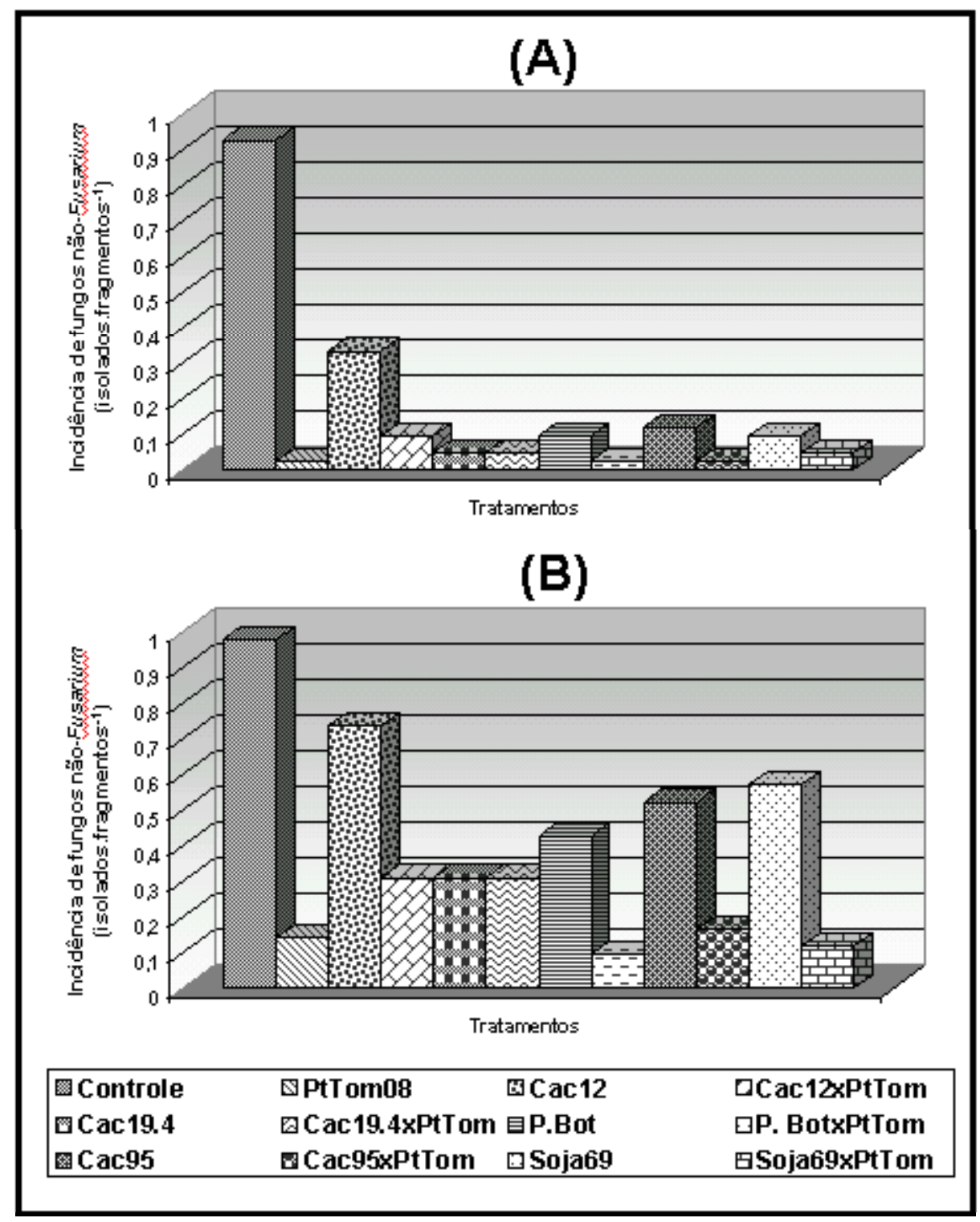

Figura 12 - Efeito da inoculação de isolados endofíticos e patogênicos de Fusarium sobre a comunidade fúngica natural de tomate: (A) Caule e (B) Raiz 
A interação fungo-planta é muito dinâmica e complexa, envolvendo diversos fatores bióticos e abióticos, os quais podem exercer uma forte pressão sobre os isolados inoculados, podendo ocasionar alterações no genoma do fungo. Deste modo é de grande importância a utilização de métodos moleculares para comprovar a identidade dos isolados recuperados.

Diante disso, para comprovar que os mesmos isolados inoculadas no experimento de controle biológico, foram recuperados no reisolamento (item 3.11.1.1), além de análises morfológicas, como coloração da colônia e morfologia dos conídios, também foi utilizada a técnica de RAPD. Com base nos resultados obtidos foi verificado que os perfis de RAPD dos isolados recuperados foram os mesmos dos isolados originais, comprovando assim, a recuperação dos isolados inoculados (Figura 14).

A técnica de RAPD também foi utilizada por Oliveira et al., (2002) para comprovar o perfil de Bipolaris sorokiniana inoculados em diferentes cultivares, resistentes e susceptíveis de trigo. Os isolados recuperados, apresentaram diferentes perfis dos isolados originais. Estes autores consideraram que estas variações encontradas ocorreram devido a forte pressão de seleção exercida pela planta hospedeira sobre estes patógenos.

Em estudos da interação fungo-planta a análise mendeliana tem sido decisiva para a descoberta de muitos princípios fundamentais. Entretanto impressionantes fenômenos foram observados na população natural de fungos que não puderam ser explicados pela herança mendeliana. Estes incluem um alto grau de mutações associadas com mudanças fenotípicas, incluindo a 
perda de patogenicidade (Bronson et al., 1990; 1990; Levi et al., 1991; Klister \& Miao, 1992).

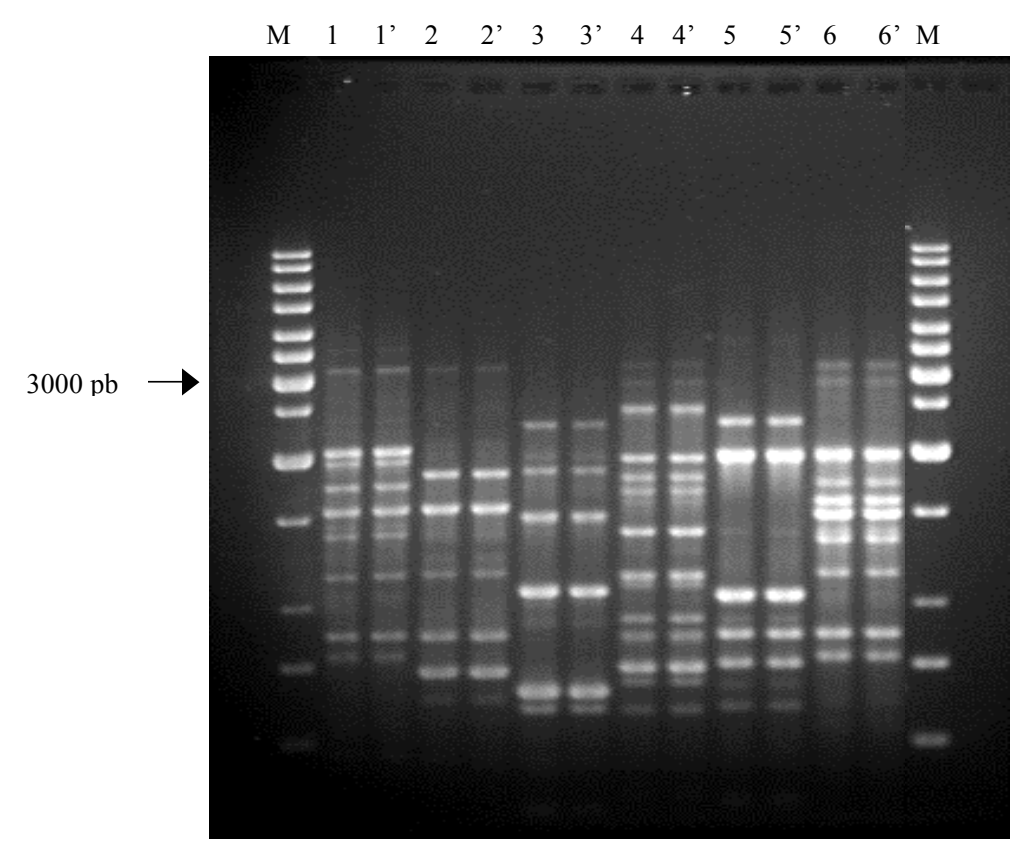

Figura 14 - Produto de amplificação de isolados de Fusarium obtidos com o primer OPW 04. M representa o marcador de peso molecular Ladder 1kb. 1 e 1' isolado Cac12 original e o isolado recuperado, respectivamente; 2 e 2' isolado Cac19.4 e o isolado recuperado; 3 e 3' isolado Cac95 e o isolado recuperado; 4 e 4' isolado P.Bot e o isolado recuperado; 5 e 5' isolado Soja69 e o isolado recuperado e 6 e 6' isolado PTtom8 e o isolado recuperado 
Com base nos resultados obtidos acima foi observado que isolados endofíticos e patogênicos foram capazes de colonizar os diferentes tecidos vegetais, caule e raiz de tomate. No entanto o isolado patogênico de tomate PtTom8 não apresentou sintomas, inviabilizando a análise da interação entre os isolados endofíticos e o isolado patogênico. Uma das possibilidades do isolado patogênico não induzir sintomas, pode ser pelo fato deste se encontrar em um estágio de latência, devido a influência de fatores bióticos ou abióticos que favoreceram o fungo a colonizar a planta mas não induzir sintomas. Segundo Rodrigues \& Redman (1997), especula-se que dependendo do estágio da dinâmica do ecossistema e da estrutura da comunidade, alguns fungos podem transitar entre pontes fisiológicas de patogenicidade endofitismo, saprofitismo e dormência.

\subsubsection{Interação de isolados de Fusarium spp. em plantas de tomate e soja}

A interação entre microrganismos endofíticos e patogênicos de culturas de importância agronômica é um ponto ainda a ser estudado, pois inúmeros fatores bioquímicos, biológicos e ecológicos podem estar envolvidos e afetam o desenvolvimento de uma estratégia de controle biológico destes patógenos (Barbieri \& Carvalho, 2001; Marcon, 2002; Peixoto Neto et al., 2004). Neste contexto, os resultados obtidos neste estudo confirmam a complexidade existente envolvendo as interações entre fungos e plantas, pois foi verificado que os isolados de Fusarium spp. (endofíticos e patogênicos) interagiram de 
forma diferente promovendo um aumento ou diminuição de peso seco no caule e raiz, tanto em soja (Figura 15) como em tomate (Figura 16).

De acordo com relatos encontrados na literatura, isolados patogênicos de Fusarium spp. mostram um alto nível de especificidade ao seu hospedeiro (Gordon \& Martyn, 1997; Huertas-Gonzáles et al., 1999; Di Pietro et al., 2003). No presente trabalho, essa especificidade foi observada com 0 isolado patogênico de soja, $F$ brasiliensise e com o isolado patogênico de tomate, $F$. o.f. sp. lycopersici que promoveram uma diminuição no peso seco de seus respectivos hospedeiros. Por outro lado, foi verificado que o isolado de Fusarium patogênico de mandioca PtMan reduziu o peso seco em tomate. De acordo com Armstrong \& Armstrong (1981), a especificidade de hospedeiro não ocorre para todas as formae speciales, de Fusarium spp. Estes mesmos autores (Armstrong \& Armstrong, 1981) verificaram que isolados de $F$. oxysporum f. sp. raphani e F.oxysporum f. sp. mathioli e raças de F.oxysporum f. sp. conglutinans (Wholl.) são igualmente patogênicos ao repolho (Brassica oleraceae L.) e rabanete (Raphanus sativus L.).

Um importante fato a ser destacado, foi verificado em relação ao isolado de Fusarium endofítico de cacau, Cac19.4, que promoveu significativamente o crescimento vegetal (Figura 17 e 18), tanto em tomate como em soja, demonstrando que este isolado poderia ser selecionado para futuras análises, visando um melhor aproveitamento deste microrganismo endofítico em estudos de interesse agronômico. Por meio de análises moleculares de ARDRA e RAPD realizadas anteriormente, foi verificado que este isolado não se agrupou com 
isolados patogênicos de Fusarium, demonstrando assim, uma maior confiabilidade deste em estudos de interesses biotecnológicos.

Portanto, os resultados encontrados no presente trabalho, são informações relevantes que poderão auxiliar no entendimento da estrutura populacional e a variabilidade genética presente neste fungo, uma vez que estes estudos poderão possibilitar em uma melhor utilização prática destes microrganismos. 


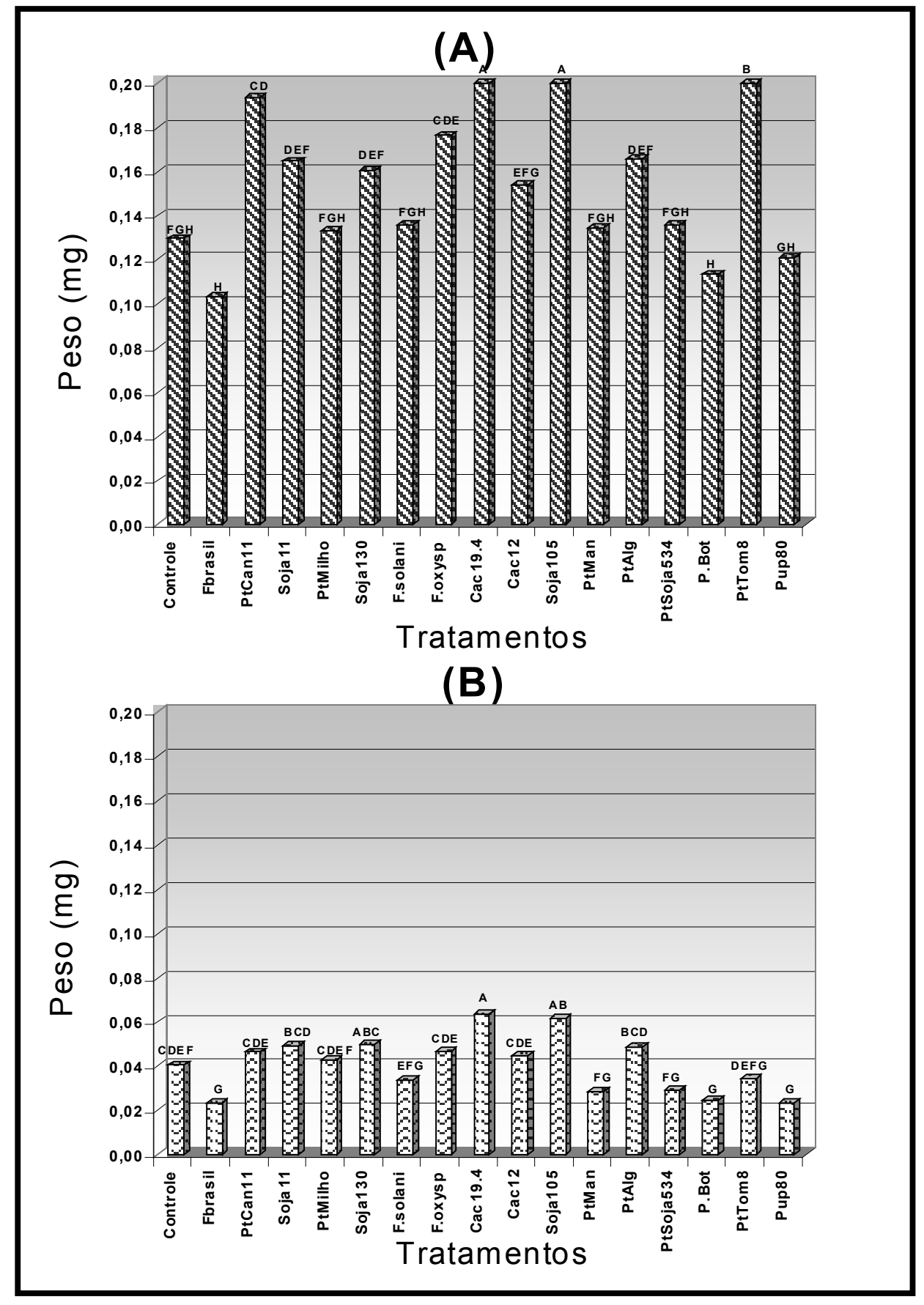

Figura 15 - Peso seco de caule e raiz de plântulas de soja avaliadas após 15 dias de inoculação com diferentes isolados de Fusarium spp. (A) representa os valores do peso seco em caule e (B) em raiz. As letras iguais não representam diferença significativa a $5 \%$ no teste de comparação de médias de Duncan 


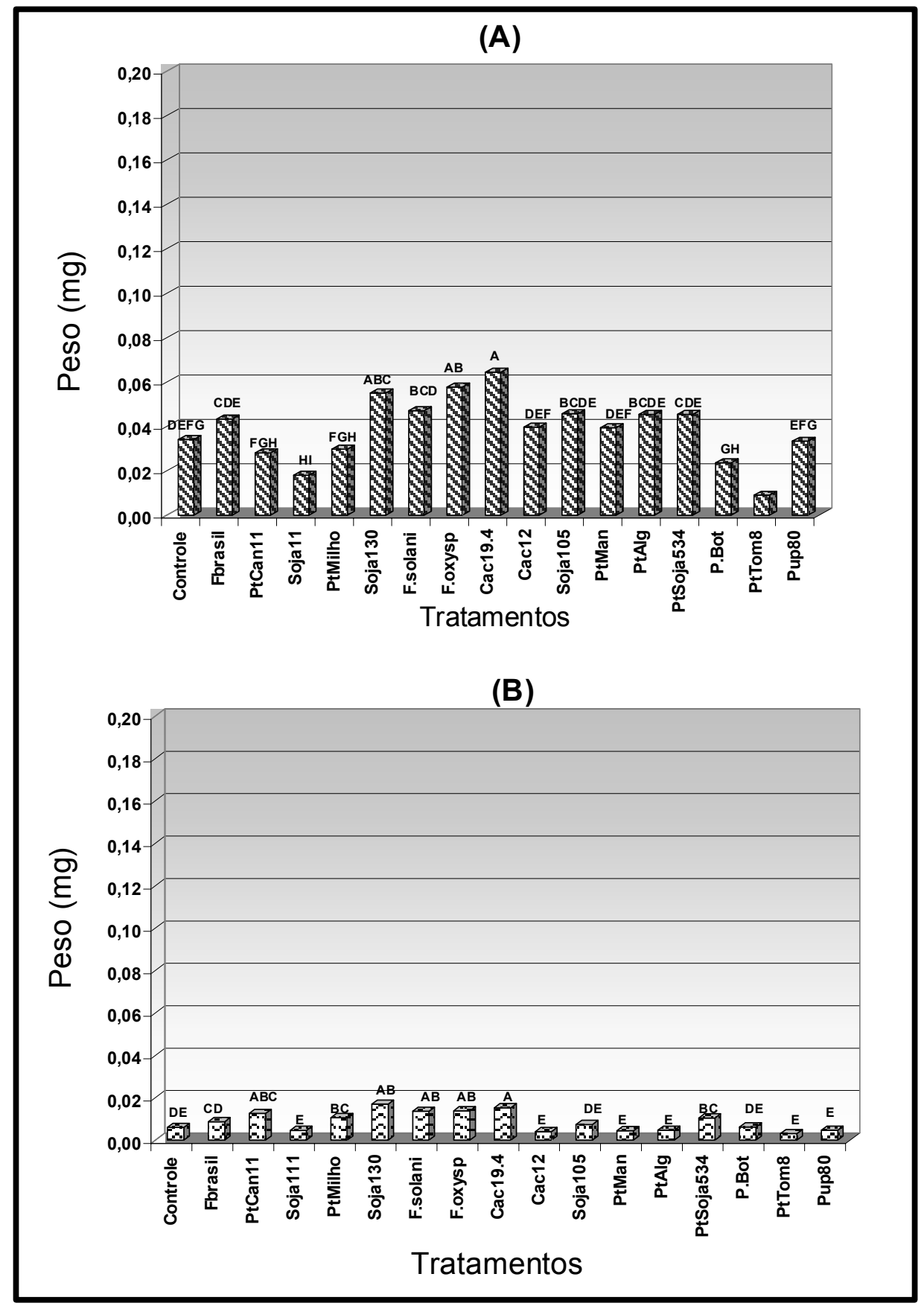

Figura 16 - Peso seco do caule e raiz de plântulas de tomate avaliadas após 15 dias de inoculação com diferentes isolados de Fusarium spp. (A) representa os valores do peso seco em caule e (B) em raiz. As letras iguais não representam diferença significativa a $5 \%$ no teste de comparação de médias de Duncan 


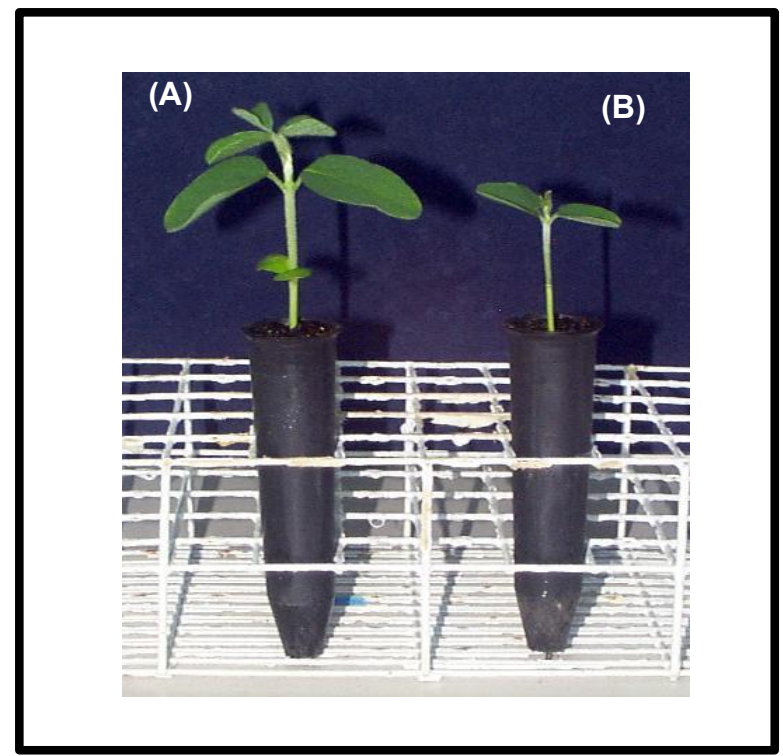

Figura 17 - Promoção de crescimento em plântulas de soja. (A) Inoculadas com Cac19.4 e (B) Controle

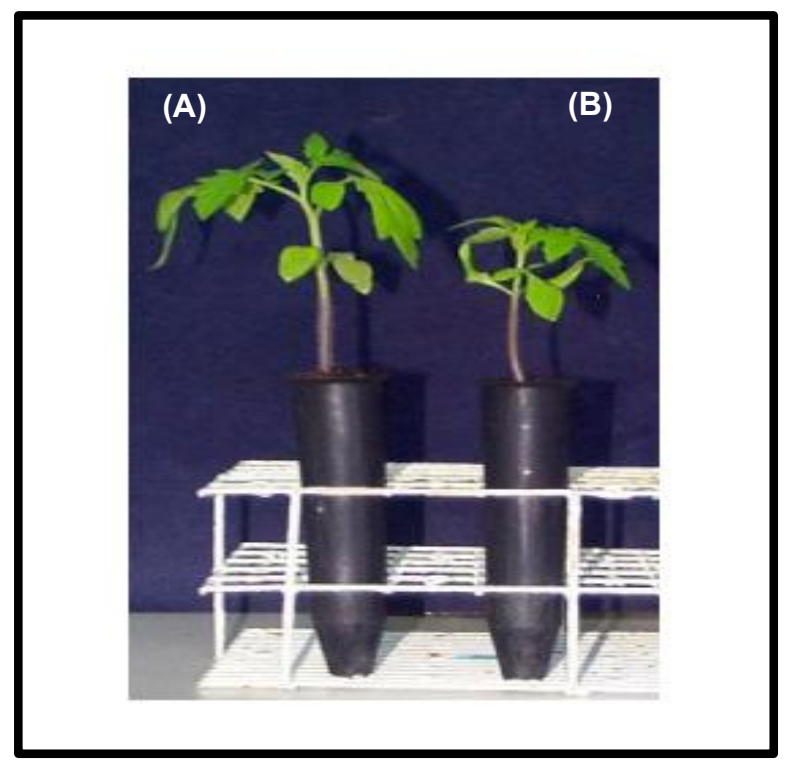

Figura 18 - Promoção de crescimento em plântulas de tomate. (A) Inocula com Cac19.4 e (B) Controle 


\section{CONCLUSÕES}

Em função dos resultados obtidos conclui-se que:

1) Existe ampla variabilidade genética entre isolados patogênicos e não patogênicos de Fusarium spp. a qual não está correlacionada com características taxonômica;

2) Os isolados patogênicos e não patogênicos de $F$. oxysporum de Soja mostraram-se geneticamente diferentes;

3) Os isolados de Fusarium spp. de Cacau, obtidos de uma mesma localidade, apresentaram grande variabilidade genética;

4) A classificação do gênero Fusarium requer uma revisão já que características fenotípicas não são concordantes com os agrupamentos obtidos por caracterização molecular;

5) Isolados endofíticos e patogênicos de Fusarium spp. são capazes de colonizar diferentes tecidos da planta hospedeira onde competem com microrganismos presentes; 
6) $\mathrm{O}$ isolado endofítico Cac19.4 mostrou-se geneticamente diferente de isolados patogênicos de Fusarium spp. além de promover um aumento do peso da raiz e caule de plântulas de soja e tomate demonstrando assim, que a interação endófito-planta pode trazer benefícios para o hospedeiro. 


\section{REFERÊNCIAS BIBLIOGRÁFICAS}

ABD-ELSALAM, K.A.; ALY, I.N.; ABDEL-SATAR, M.A.; KHALIL, M.S.; VERREET, J.A. PCR identification of Fusarium genus based on nuclearribosomal-DNA sequence data. African Journal of Biotechnology, v.2, p.82-85, 2003.

AGRIOS, G.N. Plant disease caused by fungi. Plant Pathology. London: Academic Press, 1997. p.245-406.

AGRIOS, G.N. Plant Pathology, 3 Ed., New York: Academic Press, 1988, $803 p$.

AMICUCCI, A.; ZAMBONELLI, A.; GUIDI, C.; STOCCHI, V. Morfological and molecular characterisation of Pulvinula consellatio ectomycorrhizae. FEMS Microbiology Letters, v.194, p.121-125, 2001.

AMOAH, B.K.; REZNOOR, H.N.; NICHOLSON, P.; MACDONALD, M.V. Variation in Fusarium section Liseola: pathogenicity and genetic studies of isolates of Fusarium moniliforme Sheldon from different hosts in Ghana. Plant Pathology, v.44, p.563-572, 1995. 
AOKI, T; O'DONNELL, K.; HOMMA, Y.; LATTANZI, A.R. Sudden-death syndrome of soybean is caused by two morphologically and phylogenetically distinct species within the Fusarium solani species complex - F. virguliforme in North America and F. tucumaniae in South America. Mycologia, v.95, p.660-684, 2003.

ARAYA, C.M.; ALLEYNE, A.T.; STEADMAN, J.R. Phenotypic and genotypic Characterization of Uromyces appendiculatus from Phaseolus vulgaris in the Americas. Plant Disease, v.88, p.830-836, 2004.

ARMSTRONG, G.M.; ARMSTRONG, J.K. Formae speciales and races of Fusarium oxysporum causing wilt diseases, p. 391-399. In: NELSON, P.E.; TOUSSOUN, T.A.; COOK, R. (Ed.). Fusarium: diseases, biology and taxonomy. Pennsylvania: The Pennsylvania State University Press, University Park, 1981, 457p.

ASSIS, S.M.P.; SILVEIRA, E.B.; MARIANO, R.I.R.; MENEZES, D. Bactérias endofíticas - Métodos de isolamento e potencial antagônico no controle da podridão negra em repolho. Summa Phytopathologica, v.24, p.216-220, 1998.

AZEVEDO, J.L. Microrganismos endofíticos. In Melo, I.S.; Azevedo, J.L. (Ed.) Ecologia Microbiana. Jaguariúna: EMBRAPA-Meio Ambiente, 1998. p.117137. 
AZEVEDO, J.L.; MACCHERONI, Jr.W.; PEREIRA, J.O.; ARAÚJO, W.L. Endophytic microrganisms: a review insect conrol and recent advances on tropical plants. Eletronic Journal of Biotechnology, v.3, 2000. http://www.ejb.org/content/vol3/isse1/full/3/4 (28/01/2005).

BACON, C.W.; HINTON D.M. Endophytic and biological control potential of Bacillus mojavensis and related species. Biological Control, v.23, p.274$284,2002$.

BARBIERI, R.L.; CARVALHO, F.I.F. Coevolução de plantas e fungos patogênicos. Revista Brasileira de Agrociência, v.7, p.79-83, 2001.

BARKA, E.A.; GOGNIES, S.; NOWAK, J., AUDRAN, J.C.; BELARBI, A. Inhibitory effect of endophyte bacteria on Botrytis cinerea and its influence to promote the grapevine growth. Biological Control, v.24, p.135-142, 2002.

BELABID, L.; BAUM, M.; FORTAS, Z.; BOUZNAD, Z.; EUJAYL, I. Pathogenic and genetic characterization of Algerian isolates of Fusarium oxysporum $\mathrm{f}$. sp. lentis by RAPD and AFLP analysis. African Journal of Biotechnology, v.3, p.25-31, 2004.

BENHAMOU, N. Potential of the mycoparasite, Verticillium lecanii, to protect citrus fruit against Penicillium digitatum, the causal agent of green mold: A comparison with the effect of chitosan. Phytopathology, v.94, p.693-705, 2004. 
BENHAMOU, N.; BRODEUR, J. Evidence for antibiosis and induced host defense reactions in the interaction between Verticillium lecanii and Penicillium digitatum, the causal agent of green mold. Phytopathology, v.90, p.932-943, 2000.

BENHAMOU, N.; GARAND, C. Cytological analysis of defense-related mechanisms induced in pea root tissues in response to colonization by nonpathogenic Fusarium oxysporum Fo47. Phytopathology, v.91, p.730$740,2001$.

BENHAMOU, N.; GARAND, C.; GOULET, A. Ability of non-pathogenic Fusarium oxysporum strain Fo47 to induce resistance against Pythium ultimum infection in cucumber. Applied and Environmental Microbiology, v.68, p.4044-4060, 2002.

BENTLEY, S.; PEGG, K.G.; DALE, J.L. Genetic variation among a world-wide collection of isolates of Fusarium oxysporum f. sp. cubense analysed by RAPD-PCR fingerprinting. Mycological Research, v.99, p.1378-1384, 1995.

BRONSON, C.R.; TAGA, M.; YODER, O.C. Genetic controland distant segregation of T-toxin production in field isolated of Cochliobolus heterostropus. Phytopathology, v.80, p. 819-823, 1990. 
BRYAN G.T, DANIELS M.J, OSBOURN A.E. Comparison of fungi within the Gaeumannomyces-Phialophora complex by analysis of ribosomal DNA sequence. Applied and Environmental Microbiology, v.61, p.681-689, 1995.

BURDON, J.J; SILK, J. Sources and patterns of diversity in plant pathogenic fungi. Phytopathology, v. 87,p.664-669, 1997.

CARBONE, I; KOHN, L. Ribosomal DNA sequences divergence within transcribed spacer 1 of the sclerotiniaceae. Mycological, v.85, p.415-427, 1997.

CARROLL, G.C. The biology of endophytism in plants with particular reference to woody perennials. In: Fokkema, N.J.; Heuvel, J. van den. Microbiology of Phyllospher, v.1, p.205-22, 1986.

CHASAN, R. Plant-pathogen encounters in edinburgh. Plant Cell, v.6, p.13321341, 1994.

CHELIUS, M.K.; TRIPLETT, E.W. The diversity of archea and bacteria in association with the roots of Zea mays L. Microbial Ecology, v.41, p.252263, 2001.

COOKE, D.E.L.; DUNCAN, J.M. Phylogenetic analysis of Phytophthora species based on ITS1 and ITS2 sequences of the ribosomal RNA gene repeat. Mycological Research, v.101, v.667-677, 1997. 
COOKE, D.E.L.; KENNEDY, D.M.; GUY, D.C.; RUSSELL, J.; UNCKLES, S.E.; DUNCAN, J.M. Relatedness of group I species of Phytophthora as assessed by randomly amplified polymorphic DNA (RAPDs) and sequences of ribossomal DNA. Mycological Research, v.100, p.297-303, 1996.

DESJARDINS, A.E.; MANANDHAR, G.; PLATTNER, R.D., MARAGOS, C.M.; SHRESTHA, K.; MCCORMICK, S.P. Occurrence of Fusarium species and mycotoxins in nepalese maize and wheat and the effect of traditional processing methods on mycotoxin levels. Journal of Agricultural and Food Chemistry, v.48, p.1377-1383, 2000.

DI PIETRO, A.; MADRID, M.P.; CARACUEL, Z.; DELGADO-JARANA, J.; RONCERO, M.I.G. Fusarium oxysporum: exploring the molecular arsenal of a vascular wilt fungus. Molecular Plant Pathology, v.4, p.315-325, 2003.

DOMSCH, K.H.; GAMS, W.; ANDERSON, T.H. Compendium of soil fungi. New York: Academic Press, 1980, 859p.

DUGGAL, A.; DUMAS, M.T.; JENG, R.S.; HUBBES, M. Ribosomal variation in six species of Fusarium. Mycopathologia, v.140, p.35-49, 1997.

DUIJFF, B.J.; GIANINAZZI-PEARSONAND, V.; LEMANCEAU, P. Involvement of the outer membrane lipopolysaccharides in the endophytic colonization of tomato roots by biocontrol Pseudomonas fluorescens strain WCS417r. New Phytologist, v.135, p.325-334, 1997. 
EDEL, $\quad$ V.; STEINBERG, $\quad$ C.; GAUTHERON, N.; RECORBET, G.; ALABOUVETTE, C. Genetic diversity of Fusarium oxysporum populations isolated from different soils in France. FEMS Microbiology Ecology, v.36, p.61-71, 2001.

FAGBOLA, O.; ABANG, M.M. Colletotrichum circinans and Colletotrichum coccodes can be distinguished by DGGE analysis of PCR-amplified $18 \mathrm{~S}$ rDNA fragments. African Journal of Biotechnology, v.3, p.195-198, 2004.

FERNÁNDEZ, F.A.; HANLIN, R.T. Mophological and RAPD analysis of Diaporthe phaseolorum from soybean. Mycologia, v.88, p.425-440, 1996.

FERREIRA, M.E; GRATTAPAGLIA, D. Introdução ao uso de marcadores na análise genética. Brasília: EMBRAPA, CENARGEN, 1996, 220p.

FRAVEL, D.; OLIVAIN, C.; ALABOUVETTE, C. Fusarium oxysporum and its biocontrol. New Phytologist, v.157, p.493-502, 2003.

FREEMAN, S.; RODRIGUEZ, R.J. Genetic conversion of a fungal plant pathogen to a non-pathogenic, endophytic mutualist. Science, v.260, p.7578, 1993.

FUNGARO, M.H.P. PCR na micologia. Biotecnologia Ciência \& Desenvolvimento, v.14, p.12-16, 2000. 
GEISER, D.M.; JIMÉNEZ-GASCO, M.M; KANG, S.; MAKALOWSKA, I.; VEERARAGHAVAN, N.; WARD, T.J.; ZHANG, N.; KULDAU, G.A.; O'DONNELL, K.. Fusarium-id v. 1.0: A DNA sequence database for identifyng Fusarium. European Journal of Plant Pathology, v.110, p.473479, 2004.

GHERBAWY, Y.A.M.H. RAPD pro/Ele analysis of isolates belonging to different formae speciales of Fusarium oxysporum. Cytologia, v.64, p.269-276, 1999.

GLIENKE-BLANCO, C. Guignardia citricarpa Kiely: análise genética, cariotípica e interação com o hospedeiro. Piracicaba, 1999. 200p. Tese (Doutorado) Escola Superior de Agricultura "Luiz de Queiroz" - Universidade de São Paulo.

GODOY, P.; COLOMBO, A.L. Biologia e relevância clínica do gênero Fusarium spp. Prática Hospitalar, v.34, p.136-140, 2004.

GOODWIN, P.H.; ANNIS, S.L. Rapid identification of genetic variation and pathotype of Leptosphaeria maculans by random amplified polymorphic DNA assay. Appied and Environmental Microbiology, v.57, p.2482-2486, 1991.

GORDON, T.R.; MARTYN, R.D. The evolutionary biology of Fusarium oxysporum. Annual Reviews Phytopathology, v.35, p.111-28, 1997. 
GUINI, R.; MEZZALAMA, M.; AMBROSOLI, R.; BARBIERIS, E.; GARIBALDI, A.; PIEDADE, S.M.S. Fusarium oxysporum strains as biocontrol agents against Fusarium wilt: efects on soil microbial biomass and activity. Pesquisa Agropecuária Brasileira, v.35, p.93-101, 2000.

GUTHRIE, P.A.I.; MAGILL, C.W.; FREDERIKSEN, R.A.; ODVODY, G.N. Random amplified polymorphic DNA markers: a systems for identifying and differentiating isolates of Colletotrichum graminicola. Phytopathology, v.82, p.832-835, 1992.

GUZMÁN, P.; GEPTS, P.; TEMPLE, S.; MKANDAWIRE, A.B.C.; GILBERTSON, R.L. Detection and differentiation of Phaeoisariopsis griseola isolates with the polymerase chain reaction and group-specific primers. Plant Disease, v.83, p.37-42, 1999.

GUZMÁN, P.; GILBERTSON, R.L.; NODARI, R.; JOHNSON, W.C.; TEMPLE, S.R.; MANDALA, D.; MIKANDAWIRE, A.B.C.; GEPTS, S. Characterization of variability in the fungus phaeoisariopsis griseola suggests coevolution with the common bean (Phaseolus vulgaris). Phytopathology, v.85, p.600607, 1995.

HERING, O.; NIRENBER, H.I. Differentiation of fusarium sambuciunum Fuckel sensu lato and related species by RAPD PCR. Mycopathologia, v. 129, p.159-164, 1995. 
HERMOSA, M.R.; GRONDONA, I.; ITURRIAGA, E.A.; DIAZ-MINGUES, J.M.; CASTRO, C.; MONTE, E.; GARCIA-ACHA, I. Molecular characterization and identification of biocontrol isolates of Trichoderma spp. Applied And Environmental Microbiology, v.66, p.1890-1898, 2000.

HERVAS, A.; LANDA, B.; JIMENEZDIAZ, R.M. Influence of chickpea genotype and Bacillus sp. on protection from Fusarium wilt by seed treatment with nonpathogenic Fusarium oxysporum. European Journal Of Plant Pathology, v.103, p.631-642, 1997.

HONG, L.; ZOU, W.X.; MENG, J.C.; HU, J.; TAN, R.X. New bioactive metabolites produced by Colletotrichum sp., an endophytic fungus in Artemisia annua. Plant Science, v.151, p.67-73, 2000.

HUERTAS-GONZÁLEZ, M.D.; RUIZ-ROLDAN, M.C.; GARCIA MACEIRA, F.I.; RONCERO, M.I.; DI PIETRO, A. Cloning and characterization of p/1 encoding an in planta-secreted pectate lyase of Fusarium oxysporum. Current Genetics, v.35, p.36-40, 1999.

JAMIL, F.F.; SARWAR, N.; SARWAR, M.; KHAN, J.A.; GEISTLINGER, J.; KAHAL, G. Genetic and pathogenic diversity within Ascochyta rabiei (Pass.) Lab. Populations in Pakistan causing blight of chickpea (Cicer arientinum L.). Physiological and Molecular Plant Pathology, v.57, p.243-254, 2000. 
JIMÉNEZ-GASCO, M. PÉREZ-ARTÉS, W.; JIMÉNEZ-DIAZ, R.M. Identification of pathogenic races $0,1 \mathrm{~B} / \mathrm{C}, 5$ and 6 of Fusarium oxysporum f. sp. ciceris with random amplified polymorphic DNA (RAPD). European Journal of Plant Pathology, v.107, p.237-248, 2001.

JORGENSEN, R.A.; CLUSTER, P.D. Modes and temps in theevolution of nuclear ribossomal DNA: new characters for evo-lutionary studies and new markers for genetic and population studies. Annual Missouri Botanical Garden, v.75, p.1238-1247, 1989.

KAHMANN, R.; BASSE, C. Fungal gene expression during pathogenesis-related development and host plant colonization. Current Opinion in Microbiology, v.4, p.374-380, 2001.

KELLY, A.; ALCALÁ-JIMÉNEZ, R.; BAINBRIDGE, B.W.; HEALE, J.B.; PÉREZARTÉS, E.; JIMÉNEZ-DÍAZ, M. Use of genetic fringerprinting and random amplified polymorphic DNA to characterize pathotypes of Fusarium oxysporum f. sp. ciceris infecting chickpea. Phytopathology, v.84, p.12931298, 1994.

KLISTER, C.H.; MIAO, V.P.W. New modes of genetic change in filamentous fungi. Annual Reviews in Phytopathology, v.30, p.131-152, 1992. 
KOLATTUKUDY, P.E.; ROGERS, L.M.; LI, D.; HWANG, C.S.; FLAISHMAN, M.A. Surface signaling in pathogenesis. Proceedings of the National Academy of Sciences USA, v.92, p.4080-4087, 1995.

KRISHNAMURTHY, K.; GNANAMANICKAM, S.S. Biological control of sheath blight of rice: induction of systemic resistance in rice by plant-associated Pseudomonas spp. Current Science, v.72, p.331-334, 1997.

KUKLINSKY-SOBRAL, J. A comunidade bacteriana endofítica e epifítica de soja (Glycine max) e estudo da interação endófitos-planta. Piracicaba, 2003. 174p. Tese (Doutorado) - Escola Superior de Agricultura "Luiz de Querioz" Universidade de São Paulo.

KUNINAGA, S.; NATSUAKI, T.; TAKEUCHI, T.; YOKOSAWA, R. Sequence variation of the rDNA ITS regions within and between anastomosis groups in Rhizoctonia solani. Current Genetics, v.32, p.237-243,1997.

LANA, T.G. Caracterização genética e fisiológica de Crinipellis perniciosa. Piracicaba, 2004. 91p. Tese (Doutorado) - Escola Superior de Agricultura "Luiz de Querioz" - Universidade de São Paulo.

LARENA, I.; SALAZAR, O.; GONZÁLEZ, V.; JULIÁN, M.C.; RUBIO, V. Design of a primer of ribosomal DNA intrnal transcribed spacer with enhaced specificity for ascomycetes. Journal of Biotechnology, v.75, p. 187-194, 1999. 
LARKIN, R.P.; FRAVEL, D.R. Mechanisms of action and dose-response relationships governing biological control of fusarium wilt of tomato by nonpathogenic Fusarium spp. Source: Phytopathology, v.89, p1152-1161, 1999.

LEAL-JUNIOR, G.A. Diagnóstico de Crinipellis perniciosa, em tecidos de Theobroma cacao e caracterização molecular e serológica de isolados coletados de vários hospedeiros. Piracicaba, 2002. 136p. Dissertação (Mestrado). Centro de Energia Nuclear na Agricultura - Universidade de São Paulo.

LESLIE, J.F.; ZELLER, K.A.; SUMMERELL, B.A. Icebergs and species in populations of Fusarium. Physiological and Molecular Plant Pathology, v.59, p.107-117, 2001.

LEVI, M.; ROMAO, J.; MARCHETTI, M.A.; HAMER, J.E. DNA fringerprinting with a dispersed repeated sequence resolves pathotype diversity in the rice blast fungus. Plant Cell, v.3, p.95-102, 1991.

LIEW, E.C.Y.; IRWING, J.A.G. Comparative studies on Phytophthora megasperma isolates from chickpea in Australia and Spain. Micological Research, v. 98, p.1284-1290, 1994.

LIU, D; van HEESWIJCK, R.; LATCH, G.; LEONFORTE, T.; PANACCIO, M.; LANGFORD, C.; CUNNINGHAM, P.; REED, K. Rapid identification of 
Acremonium Iolii and Acremonium coenophialum endophytes trough arbitrarily primed PCR. FEMS Microbiology Letters, v.133, p.95-98, 1995.

LIYANAGE, H.D.; McMILLAN JUNIOR, R.T.; KISTLER, H.C. Two genetically distinct populations of Colletotrichum goesporioides from citrus. Phytopatology, v.82, p.1371-1376, 1992.

MARCON, J. Isolamento e caracterização genética de actinomicetos endofíticos de Citrus spp. e interação com Xylella fastidiosa. Piracicaba, 2002. 91p. Dissertação (Mestrado) - Instituto de Ciências Biomédicas - Universidade de São Paulo.

MARSHALL, M.N.; COCOLIN, L.; MILLS, D.A.; VANDERGREYNST, J.S. Evaluation of PCR primers for denaturing gradient gel electroforesis analysis of fungal communities in compost. Journal of Applied Microbiology, v.95, p.934-948, 2003.

McDONALD, B.A. The population genetics of fungi: tools and techniques. Phytopathology, v.87, p.448-453, 1997.

McONEI, K.C. The latent occurrence in citrus and other hosts of a Guignardia easily confused with G. citricarpa, the citrus black spot pathogen. Phytopathology, v.54, p.40-43, 1964.

MÊS, J.J.; WESTSTEIJN, E.A.; HERLAAR, F.; LAMBALK, J.J.M.; WIJBRANDI, J.; HARING, M.A. Biological and molecular characterization of Fusarium 
oxysporum f sp lycopersici divides race 1 isolates into separate virulence groups. Phytopathology, v.89, p.156-160, 1999.

MICHELMORE, R.W.; PARAN, I.; KESSELI, R.V. Identification of markers linked to disease-resitence genes by bulked segregant analysis: A rapid method to detect markers in specific genomic regions by using segregating populations. Proceeding of the National Academy of Science, v.88, p. 828-982, 1991.

MOLLER, E.M.; CHELKOWSKI, J.; GEISER, H.H. Species-specific PCR assays for the fungal pathogens Fusarium moniliforme and Fusariumsubglutinans and their application to diagnose maize ear rot disease. Journal of Phytopathology, v.147, p.497-508, 1999.

MORICCA, S.; RAGAZZI, A.; KASUGA, T.; MITCHELSON, K.R. Detection of Fusarium oxysporum f. sp. vasinfectum in cotton tissue by polymerase chain reaction. Plant Patholology, v.47, p.486-494, 1998.

MOSTAFA, M; REZA, Z. M.; OMID, J.; JAVAD, H. M. Use of rapd, enzyme activity staining, and colony size to differentiate phytopathogenic Fusarium oxysporum isolates from Iran. Brazilian Journal of Microbiology, v. 33, p.299-303, 2002. 
M'PIGA, P.; BÉLANGER, R.R.; PAULITZ, T.C.; BENHAMOU, N. Increased resistance to Fusarium oxysporum f. sp. radicis-licopersici in tomato plants treated with the endophytic bacterium Pseudomonas fluorescens strain 6328. Physiological and Molecular Plant Pathology, v.50, p.301-320, 1997.

NARISAWA, K.; KAWAMATA, H.; CURRAH, R.S.; HASHIBA; T. Suppression of Verticillium wilt in eggplant by some fungal root endophytes. European Journal of Plant Pathology, v.108, p.103-109, 2002.

NARISAWA, K.; OHKI, T.; HASHIBA. T. Suppression of clubroot and Verticillium yellows in Chinese cabbage in the field by the endophytic fungus, Heteroconium chaetospira. Plant Pathology, v.49, p.141-146, 2000.

NAZAR, R.N.; HU, X.; SCHMIDT. J.; CULHAM, D.; ROBB, J. Potential use of PCR-amplified ribosomal intergenic sequences in the detection and differentiation of Verticillium wilt pathogens. Physiological and Molecular Plant Pathology, v.39, p1-11, 1991.

NELSON, A.J.; ELIAS, K.S.; ARÉVALO, E.G.; DARLINGTON, L.C.; BAILEY, B.A. Genetic characterization by RAPD analysis of isolates of Fusarium oxysporum f. sp. erythroxyli associated with an emerging epidemic in Peru. Phytopathology, v87, p.1220-1225, 1997. 
NELSON, P.E.; TOUSSOUN, T.A.; COOK, R.J. (Ed.) Fusarium: diseases, biology, and taxonomy. Pennsylvania: The Pennsylvania State University, 1981. p.289-290.

OLIVAIN, C.; ALABOUVETTE, C. Process of tomato root colonization by a pathogenic strain of Fusarium oxysporum f. sp. lycopersici in comparison with a non-pathogenic strain. New Phytologist, v.141, p.497-510, 1999.

OLIVEIRA, A.M.R.; MATSUMURA, A.T.S.; PRESTES, A.M.; VAN DER SAND, S.T. Intraspecific variability of Bipolaris sorokiniana isolates determined by random-amplified polymorphic DNA (RAPD). Genetics and Molecular Reserch, v.1, p.350-358, 2002.

OLIVEIRA, V.C.; COSTA, J.L.S. Análise de restrição de DNA ribossomal amplificado (ARDRA) pode diferenciar Fusarium solani f. sp. phaseoli de $F$. solani f. sp. glycines. Fitopatologia Brasileira, v.27, p.631-634, 2002.

OVREAS, L.; TORSVIK, V. Microbial diversity and community structure in two different agricultural soil communities. Microbial Ecology, v.36, p.303-315, 1998.

PAMPHILE, J.A.; AZEVEDO, J.L. Molecular characterization of endophytic strains of Fusarium verticillioides (=Fusarium moniliforme) from maize Zea mays. L. World Journal of Microbiology \& Biotechnology, v.18, p.391396, 2002. 
PAN M. J., RADEMAN S, KUNERT K, HASTINGS J.W. Ultrastructural studies on the colonization of banana tissue and Fusarium oxysporum f. sp. cubense race 4 by the endophytic bacterium Burkholderia cepacia. Journal of Phytopathology-Phytopathologische Zeitschrift, v.145, p.479-486, 1997.

PASQUALI, M.; ACQUADRO, A.; BALMAS, V.; MICHELI, Q.; GARIBALDI, A.; GULLINO, M.L. RAPD characterization of Fusarium oxysporum isolates pathogenic on Argyranthemum frutencens L. Journal Phytopathology, v.151, p.30-35, 2003.

PEIXOTO-NETO, P.A.S.; AZEVEDO, J.L; CAETANO, L.C. Microrganismos endofíticos em plantas: Status atual e perspectivas. Boletin Latinoamericano y del Caribe de Plantas Medicinales y Aromaticas, v.3, p.66-79, 2004.

PENNANEN, T.; PAAVOLAINEN, L.; HANTULA, J. Rapid PCR-based method for the direct analysis of fungal communities in complex environmental samples. Soil Biology \& Biochemistry, v.33, p.697-699, 2001.

PETRINI, O. Fungal endophyte of tree leaves. In: Andrews, J.; Hirano, S.S.

(Ed.) Microbial Ecology of Leaves. New York: Spring Verlag, 1991. p.179-197. 
PIANZZOLA, M.J.; MOSCATELLI, M.; VERO, S. Characterizaton of Penicillium isolates associated with blue mold on apple in Uruguay. Plant Disease, v.88, p.23-28, 2004.

POSTMA, J.; LUTTIKHOLT, A.J.G. Colonization of carnation stems by a nonpathogenic isolate of Fusarium oxysporum and its effect on Fusarium oxysporum $\mathrm{f} s \mathrm{~s}$ dianthi. Canadian Journal of Botany-Revue Canadienne de Botanique, v.74, p.1841-1851, 1996.

PUHALLA, J.E. Genetic considerations of the genus Fusarium. In: Nelson, P.E.; Toussoun, T.A.; Cook, R.J. (Ed) Fusarium: diseases, biology, and taxonomy. Pennsylvania: Pennsylvania State University, v.27, p.291-305, 1981.

QIN Q.; BERGMANN, C.W.; ROSE, J.K.C.; SALADIE, M.; KOLLI, V.S.K.; ALBERSHEIM, P.; DARVILL, A.G.; YORK, W.S. Characterization of a tomato protein that inhibits a xyloglucan-specific endoglucanase. Plant Journal, v.34, p.327-338, 2003.

RAEDER, U.; BRODA, P. Rapid preparation of DNA from filamentous fungi. Letters in Applied Microbiology, v.1, p.17-20, 1985.

RAUPACH, GS.; KLOEPPER, J.W. Mixtures of plant growth-promoting rhizobacteria enhance biological control of multiple cucumber pathogens. Phytopathology, v.88, p.1158-1164, 1998. 
RODRIGUES, R.J; REDMAN, R.S. Fungal life-styles and ecossistem dynamics: Biological aspects of plant pathogens, plant endophytes and saprophytes. Advances in Botany Research, v.24, p.169-193, 1997.

ROY, S.; SIMON, J.P.; LAPOINTRE, F.J. Determination of origin of the coldadapted populations of barnyard grass (Echinochloa crusgalli) in eastern North America: a total-evidence approach using RAPD DNA and DNA sequences. Canadian Journal of Botany, v.78, p.1501-1513, 2000.

RUBIO, J.; HAJJ-MOUSSA, E.; KHARRAT, M.; MORENO, M.T; MILLAN, T.; GIL, J. Two genes and linked RAPD markers involved in resistance to Fusarium oxysporum f. sp ciceris race 0 in chickpea. Plant Breeding, v.122, p.188-191, 2003.

SALERNO, M.I.; GIANINAZZI, S.; GIANINAZZI, P. Effects on growth and comparison of root tissue colonization patters of Eucalyptus viminalis by pathogenic and non-pathogenic strains of Fusarium oxysporum. New Phytologist, v.146, p.317-324, 2000.

SAMBROOK, J.; FRITSCH, E.F.; MANIATIS, T. Molecular cloning: A laboratory manual. 2.ed. New York: Cold Spring Harbor Laboratory Press, 1989. 
SANABRIA, N.A.; GUADARRAMA, A.; ROMERO, H. Caracterización de especies de Fusarium mediante patrones electroforéticos de proteínas. Revista de la Facultad de Agronomia, v.28, p.161-173, 2002.

SCHÄFER, G; WÖSTEMEYER, J. Random primer dependent PCR differentiates aggressove from non-aggressive isolates of the oilseed rape pathogen phoma lingam (Leptosphaeria maculans). Journal Phytopathology, v.136, p.124-136, 1992.

SHARMA, V.K.; NOWAK, J. Enhancement of verticillium wilt resistance in tomato transplants by in vitro co-culture of seedlings with a plant growth promoting rhizobacterium (Pseudomonas sp. strain PsJN). Canadian Journal Microbiology, v.44, p.528-536, 1998.

SILVA-MANN, R.; SALGADO, K.C.C.; VIEIRA M.G.G.C.; MACHADO, J.C. Variabilidade genética de isolados do complexo Colletotrichum associados a sementes de algodoeiro, por meio de técnicas moleculares e inoculação em plantas. Fitopatologia Brasileira, v.27, p27-32, 2002.

SIVARAMAKRISHNAN, S.; KANNAN, S.; SINGH, S.D. Genetic variability of Fusarium wilt pathogen isolates of chickpea (Cicer arietinum L.) assessed by molecular markers. Mycopathologia, v.155, p.171-178, 2002. 
SKOUBOE, P.; FRISVAD, J.C., TAYLOR J.W., LAURITSEN, D.; BOYSEN M.; ROSSEN, L. Phylogenetic analysis of nucleotide sequences from the ITS region of terverticillate Penicillium species. Mycological Research, v.103, p.873-881, 1999.

SNYDER, W.C.; HANSEN, H.N. Species concept, genetics, and pathogenicity in Hypomyces solani. Phytopathology, v.44, p.338-342, 1953.

STURZ, A.V.; CHRISTIE, B.R.; NOWAK, J. Bacterial endophytes: Potencial role in developing sustainable systems of crop production. Critical Reviews in Plant Sciences, v.19, p.1-30, 2000.

STURZ, A.V.; MATHESON, B.G. Populations of endophytic bacteria which influence host-resistance to Erwinia-induced bacterial soft rot in potato tubers. Plant Soil, v.184, p.265-271, 1996.

SUMMERELL, B.A.; LESLIE, J.F. A utilitarian approach to Fusarium identification. Plant Disease, v.87, p.117-128, 2003.

SUTTON, J.C. Strategies for biological control of necrotrophic pathogens in perennial crops. Fitopatologia Brasileira, v.25, p.235-238, 2000.

TAYLOR, E.; BATES, J.; KENYON, D.; MACCAFERRI, M.; THOMAS, J. Modern molecular methods for characterization and diagnosis of seed-borne fungal pathogens. Journal of Plant Pathology, v.83, p.75-81, 2001. 
TOKESHI, H. Doenças e pragas agrícolas geradas e multiplicadas pelos agrotóxicos. Fitopatologia Brasileira, v.25, p.264-271, 2000.

TOYOTA, K.; KITAMURA, M.; KIMURA, M. Supression of Fusarium oxysporum f. sp. raphini PEG-4 in soil following colonization by other Fusarium spp.Soil Biology \& Biochemistry, v.27, p.41-47, 1995.

VAKALOUNAKIS, D.J.; FRAGKIADAKIS, G.A. Genetic fdiversity of Fusarium oxysporum isolates from cucumber: differentiation by pathogenic, vegetative, compatibility, and RAPD fringerprinting. Phytopathology, v.89, p.161-168, 1999.

VAN ELSAS, J.D.; DUARTE. G.F.; ROSADO. A.S.; SMALLA, K. Microbiological an molecular biological methods for monitoring microbial inoculants and their effects in the soil environmental. Journal of Microbiological Methods, v.32, p.133-154, 1998.

VARMA, A.; VERMA, S.; SUDHA; SAHAY, N.; BÜTEHORN, B.; FRANKEN, P. Piriformospora indica, a cultivable plant-growth promoting root endophyte. Applied and Environmental Microbiology, v.65, p.2741-2744, 1999.

VIRET, O.; PETRINI. O. Colonization of beech leaves (Fagus sylvatica) by the endophyte Discula umbrinella (teleomorph, Apiognomonia errabunda. Mycological Research, v.98, p.423-432, 1994. 
WAGNER, B.L. \& LEWIS, L.C. Colonization of corn, Zea mays, by the entomopathogenic fungus Beauveria bassiana. Applied and Environmental Microbiology, v.66, p.3468-3473, 2000.

WANG, P.H.; LO, H.S.; YEH, Y. Identification of $F$. o. cucumerinum and $F$. o. luffae by RAPD-generated DNA probes. Letters in Applied Microbiology, v.33, p.397-401, 2001.

WELSH, J.; MCCLELLAND, M. Fingerprinting genomes using PCR witharbitrary primers. Nucleic Acids Research, v.18, p.7213-7218, 1990.

WILLIAMS, J.G.K.; KUBELIK, A.R.; LIVAK, K.J.; RAFALSKI, J.A.; TINGEY, S.V. DNA polymorphisms amplified by arbitrary primers are useful as genetic markers. Nucleic Acids Research, v.18, p.6531-6535, 1990.

WILLIAMS, J.G.K.;HANAFEY, M.K.; RAFALSKI, J.A. Genetic analysis using random amplified polymorphic DNA markers. Methods in Enzymology, v.218, p.704-740, 1993.

WRIGHT, G.F.K.; GUEST, D.I.; WILMALAJEEWA, D.L.S.; van HEESWIJCK, R. Characterization of Fusarium oxysporum isolates from carnation in Astrália based on pathogenic, vegetative compatibility and random amplified polymorphic DNA (RAPD) assay. European Journal of Plant Pathology, v.102, p. 451-457, 1996. 
YLI-MATTILA, T.; PAAVANEN, S.; HANNUKKALA, A.; PARIKKA, P.; TAHVONEN, R.; KARJALAINEN, R. Isozme and RAPD-PCR analyses of Fusarium avenaceum strains from Finland. Plant Pathology, v.45, p.126134, 1996.

YUAN, G.F.; LIU, C.S.; CHEN, C.C. Differentiation on Aspergillus parasiticus from Aspergillus sojae by random amplification of polymorphic DNA. Applied and Environmental Microbiology, v.61, p.2384-2387, 1995.

ZEMANKOVA, M. LEBEDA, A. Fusarium species, their taxonomy, variability and significance in plant pathology. Review. Plant Protection Science UZPI, v.37, p.25-42, 2001.

ZHENG, X.Y.; WOLFF, D.W. Randomly amplified polymorphic DNA markers linked to Fusarium wilt resistance in diverse melons. Hortscience, v.35, p.716-721, 2000. 